UNIVERSIDADE FEDERAL DO RIO GRANDE DO SUL INSTITUTO DE FILOSOFIA E CIÊNCIAS HUMANAS PROGRAMA DE PÓS-GRADUAÇÃO EM HISTÓRIA

A ALDEIA DE SÃO NICOLAU DO RIO PARDO:

HISTÓRIAS VIVIDAS POR ÍNDIOS GUARANIS (SÉCULOS XVIII-XIX)

KARINA MOREIRA RIBEIRO DA SILVA E MELO

Dissertação de mestrado apresentada ao Programa de Pós-Graduação em História da Universidade Federal do Rio Grande do Sul como requisito para obtenção do grau de mestre em História

Orientador: Prof. Dr. Eduardo Santos Neumann

Porto Alegre, março de 2011 


\title{
A ALDEIA DE SÃO NICOLAU DO RIO PARDO: HISTÓRIAS VIVIDAS POR ÍNDIOS GUARANIS (SÉCULOS XVIII-XIX)
}

\author{
KARINA MOREIRA RIBEIRO DA SILVA E MELO
}

Dissertação de mestrado apresentada ao Programa de Pós-Graduação em História da Universidade Federal do Rio Grande do Sul como requisito para obtenção do grau de mestre em História

Banca Examinadora:

Prof. Dr. Eduardo Santos Neumann - Orientador Universidade Federal do Rio Grande do Sul

Prof. Dr. John Manuel Monteiro

Universidade Estadual de Campinas

Prof. Dr. Guillermo Wilde

Universidad Nacional de San Martín (Buenos Aires)

Prof. Dr. Fábio Kühn

Universidade Federal do Rio Grande do Sul 


\section{RESUMO}

Esta dissertação tem como objetivo principal compreender aspectos sobre a formação, manutenção e extinção do aldeamento de São Nicolau do Rio Pardo. De meados do século XVIII até o terceiro quartel do XIX ele se manteve como um espaço eminentemente indígena. Durante os oitocentos sua trajetória e as histórias das pessoas que o compuseram são menos conhecidas. Assim, procura-se recompor as relações sociais e de poder em que estiveram inseridos os indígenas, levando em conta seus papéis de agentes sociais, percebendo suas participações ativas no processo histórico a partir dos contatos que eles estabeleceram com outros agentes. As fontes históricas centrais são documentos da Diretoria Geral dos Índios e do aldeamento, ofícios, editais e correspondências da câmara de vereadores de Rio Pardo, relatórios de presidente de Província e relatos de viajantes. Além disso, a pesquisa aborda questões sobre aspectos que envolvem disputas entre os índios e a sociedade envolvente pelas terras do aldeamento, suas participações nas guerras

provinciais e os discursos políticos e eclesiásticos produzidos sobre eles. Tais elementos podem ser articulados com processos de formação de identidade dos índios guaranis no sul do Brasil. 


\begin{abstract}
This dissertation's main objective is to understand aspects of the formation, maintenance and dissolution of the village of São Nicolau do Rio Pardo. From the mid eighteenth century until the third quarter of the nineteenth he has remained as a predominantly indigenous area. During his career on the eighteenth the stories of people who composed it are less known. Thus, attempts to reconstruct the social and power relations that were inserted into the Indians, taking into account their roles as social actors, perceiving their active participation in the historical process from which they establish contacts with other agents. The central historical sources are documents of the General Directorate of the Indians and of the village, letters, notices and correspondence from the city council of Rio Pardo, president of Province reports and reports of travelers. Moreover, the research addresses issues about aspects involving disputes between the Indians and the surrounding society for the lands of the village, their participation in provincial wars and political and church speeches produced on them. These elements can be linked with processes of identity formation of the Guarani Indians in southern Brazil.
\end{abstract}




\section{SUMÁRIO}

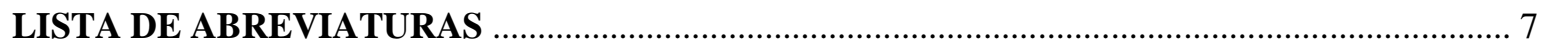

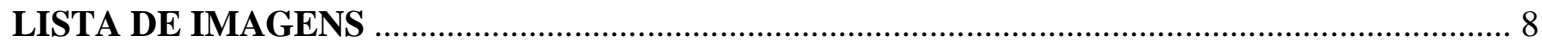

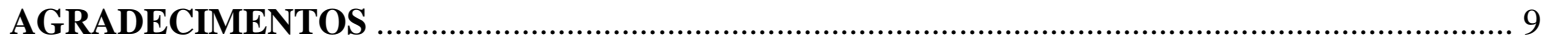

INTRODUÇÃ

CAPÍTULO 1 - OS INDÍGENAS NA PROVÍNCIA DE SÃO PEDRO: ENTRE PRÁTICAS E

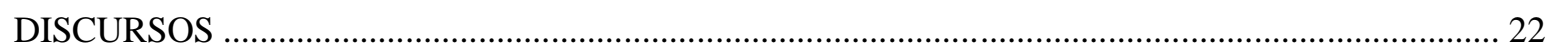

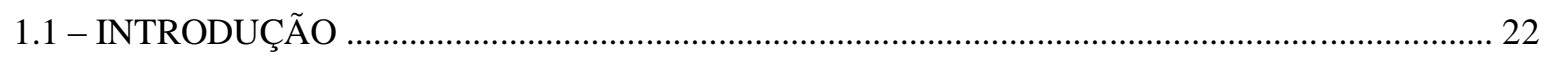

1.2 - PRÁTICAS INDÍGENAS NOS DISCURSOS POLÍTICOS ..................................................... 26

1.3 - PRÁTICAS INDÍGENAS NOS DISCURSOS ECLESIÁSTICOS ............................................ 32

CAPÍTULO 2 - A ALDEIA DE SÃO NICOLAU DO RIO PARDO ................................................ 47

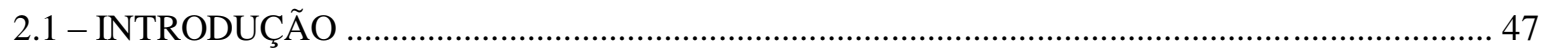

2.2 - LUGAR DE CASTIGO OU RECOMPENSA PARA DESERTORES E 'CHINAS' ................... 50

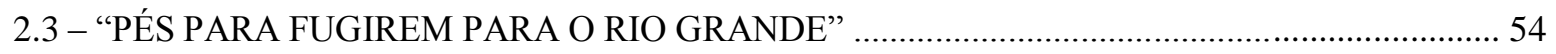

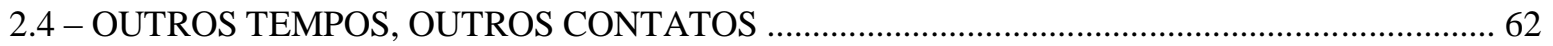

CAPÍTULO 3 - ENTRE TERRAS E TERRITÓRIOS: IDENTIDADES INDÍGENAS EM

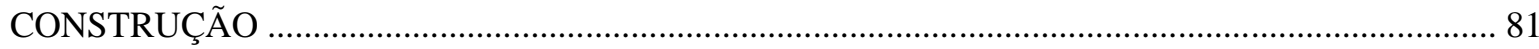

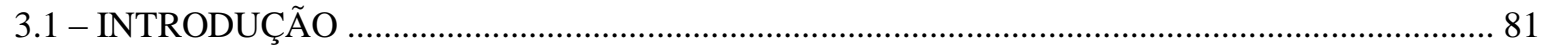

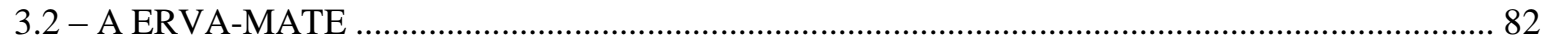

3.3 - A IGREJA DE SÃO NICOLAU DO RIO PARDO ……....................................................... 90

3.4 - DISPUTAS POR TERRAS E DIREITOS TERRITORIAIS ……............................................ 95

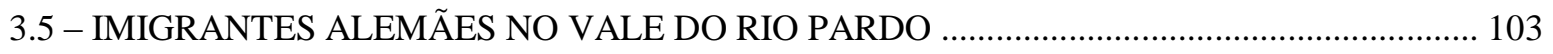

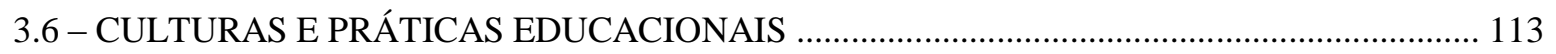


CAPÍTULO 4 - SOBRE GUERRAS E GUARANIS EM TEMPOS PROVINCIAIS 121

4.1 - INTRODUÇÃO 122

4.2 - GUARANIS EM ARMAS 128

4.3 - "O PESO DA ESPADA OU DA LANÇA" 136

4.4 - "ESTES ÍNDIOS SÃO BONS SOLDADOS" 146

CONSIDERAÇÕES FINAIS 155

LOCAIS DE PESQUISA 157

FONTES 157

BIBLIOGRAFIA 159 


\section{LISTA DE ABREVIATURAS}

AGN - Archivo General de la Nación (Argentina)

AGS - Archivo General de Simancas (Espanha)

AHMRP - Arquivo Histórico Municipal de Rio Pardo

AHPA - Arquivo Histórico de Porto Alegre

AHRS - Arquivo Histórico do Rio Grande do Sul

ANRJ - Arquivo Nacional do Rio de Janeiro

BNL - Biblioteca Nacional de Lisboa

BNRJ - Biblioteca Nacional do Rio de Janeiro

IHGRGS - Instituto Histórico e Geográfico do Rio Grande do Sul

Cx. - caixa

Cód. - Códice

$\mathrm{Fl}$ - folha

Not. - notação

V - verso

$\mathrm{Mç}-$ maço

Vol - volume 


\section{LISTA DE IMAGENS}

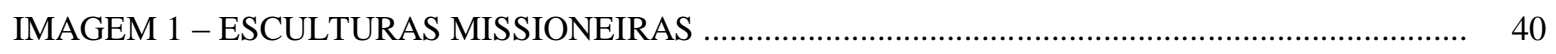

IMAGEM 2 - MAPA DAS PRIMEIRAS POVOAÇÕES DO RIO GRANDE DO SUL .......................... 49

IMAGEM 3 - MAPA DO TERRITÓRIO DOS TRINTA POVOS JESUÍTICO-GUARANI E SUAS

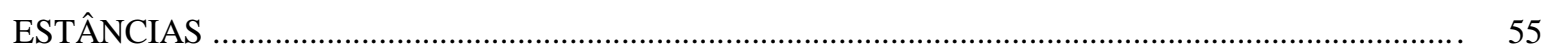

IMAGEM 4 - TIJOLO COM DIZERES GRAVADOS EM GUARANI E ESPANHOL ........................

IMAGEM 5 - MAPA DOS TOLDOS INDÍGENAS NO RIO GRANDE DO SUL ................................... 73

IMAGEM 6 - ÍNDIOS GUARANIS DO ALDEAMENTO DE LAGOÃO DA SERRINHA .................. 79

IMAGEM 7 - ATUAL IGREJA DA ALDEIA DE SÃO NICOLAU DO RIO PARDO ........................... 94

IMAGEM 8 - MAPA DOS MUNICÍPIOS DO RIO GRANDE DO SUL EM 1858 .............................. 107

IMAGEM 9 - LEONCINA TATSCH ……................................................................................ 112

IMAGEM 10 - MAPA DO TEATRO DA GUERRA NA PROVÍNCIA DE SÃO PEDRO …................. 127 
AGRADECIMENTOS

Muitas pessoas, acontecimentos e instituições fizeram parte dessa pesquisa iniciada há cerca de três anos. Agradeço primeiramente à minha família, cuja presença é constante apesar da distância. Aos meus pais, Walter e Carminha, pelo apoio e pela torcida em relação aos estudos desde tempos atrás. Ao meu irmão Júnior, pelas horas de alegria que passamos em companhia do amado sobrinho Gabriel. Ao meu irmão Rui, por dividirmos momentos especiais durante nossas idas e vindas.

Aos colegas de graduação no curso de História da UFRGS agradeço pelo aprendizado que fizemos juntos. Aos professores, obrigada pela importância que seus ensinamentos tiveram em minha formação como historiadora. A Adriana Schmidt Dias, pelos incentivos e desafios que proporcionou ao longo das etapas da vida acadêmica, a começar pelas excelentes aulas sobre pré-história e arqueologia. Agradeço também por ter possibilitado a realização de outro importante projeto acadêmico. A Anderson Vargas, pelo bom humor e acolhida logo no começo da graduação. A José Otávio Catafesto, pelas aulas de antropologia instigadoras da minha pesquisa. A Benito Schmidt, pelos ótimos apontamentos sobre o trabalho de conclusão de curso. A Cláudia Mauch, cuja competência e seriedade são exemplares, pela leitura do trabalho na fase inicial da pesquisa. A Luiz Dario, Enrique Padrós e Silvia Petersen, pela honra em ouvir suas explicações inteligentes, seus conselhos e incentivos.

A Fábio Kühn, que me orientou durante a iniciação científica, agradeço especialmente pelo aprendizado sobre o trabalho nos arquivos históricos. O trabalho em seu projeto possibilitou o acesso a fontes importantes, algumas das quais utilizadas neste estudo. Obrigada, ainda, pelo aceite do convite para compor a banca de defesa da dissertação.

A Eduardo Neumann, que instiga e motiva minha pesquisa desde a graduação, agradeço pelo aprendizado durante as aulas e pelas palavras de estímulo e confiança durante a orientação no mestrado. Não posso deixar de mencionar a liberdade concedida na definição dos rumos da pesquisa, o apoio e a compreensão do meu envolvimento com atividades acadêmicas afins. 
A Elisa Garcia agradeço pelas dicas, comentários e sugestões valiosas ao longo do trabalho.

A Guillermo Wilde, por ter ajudado e incentivado na realização de projetos durante o mestrado e por ter aceitado o convite para compor a banca de defesa.

A John Manuel Monteiro, obrigada pela boa vontade e pelo apoio dado em momentos diferentes e importantes ao longo da pesquisa. Agradeço também por ter aceitado o convite para compor a banca de defesa.

Agradeço colegas e amigos que em diversos momentos me ajudaram com várias dicas e conversas: Bruna Sirtori, Cláudia Feijó, Juliana Pozzo Tatsch, Miguel Stédile, Roberta Porto Marques, Roberta Zettel e Vherá Poty Benites da Silva.

A Cássia Silveira, Danilo Braga, Flávia Renata, Juliana Medeiros, Lourdes e família, Maurício Minuzzo, Rafael Caruccio, Rose Lopes, Soraia Dornelles, Telma Almeida, Vanessa e Cinara Moura, agradeço pela amizade. À Soraia Dornelles, além da amizade, agradeço por compartilharmos tantas coisas e tantos projetos.

Aos amigos e parentes, vô Júlio, madrinha Nina, Adriana, Henri, Pedro Henrique, Raquel Artiaga, Flávia Araújo, Cris Boletti, Andréia Pontello, Ronaldo Fernandes e Emylliane Pereira. Os reencontros são sempre uma alegria.

Agradeço a Leoncina (in memorian) e Eloy Tatsch pelas entrevistas concedidas.

Ao CNPq, cuja bolsa foi muito importante para a minha dedicação integral aos estudos e demais atividades acadêmicas.

Aos funcionários dos arquivos históricos onde pesquisei agradeço pela prestatividade. Em especial, agradeço a Daniela Oliveira e Fábia Winck. Sem elas eu demoraria muito a encontrar os documentos de que precisava no Arquivo Histórico do Município de Rio Pardo.

Por último e mais importante, agradeço, por tudo, a Marcos Melo, meu grande amor. 
INTRODUÇÃO

A história do aldeamento de São Nicolau do Rio Pardo contou com a atuação de várias pessoas, indígenas e não-indígenas. Índios guaranis, autoridades coloniais e provinciais, escravos, negros, missionários, eclesiásticos, índios coroados, viajantes, imigrantes alemães e italianos se encontraram e relacionaram de diversas maneiras ao longo do período em que o aldeamento foi fundado e extinto (1757- década de 1860). Alguns dos atos praticados por tais personagens foram registrados, e, através das fontes históricas esses sujeitos revelam que a complexidade de suas ações e a riqueza de seus significados nem sempre ocuparam a devida importância nos estudos históricos.

Este trabalho é sobre situações e experiências vividas por muitas dessas personagens, com enfoque para aquelas das quais as histórias são menos conhecidas. Muitas vezes deixadas à parte, as ações dos índios guaranis são fundamentais para entender a importância de seu papel na história da Província de São Pedro, e ao mesmo tempo para torná-la mais complexa e real. Há muitos estudos sobre os tratados e as guerras que ocorreram nos séculos XVIII e XIX. São igualmente numerosos os trabalhos sobre a ocupação e a disputa de terras entre portugueses e espanhóis, sobre a chegada dos imigrantes alemães e italianos e por fim, sobre a presença européia no território da Província de São Pedro. Menos numerosos, mas existentes, são os trabalhos sobre negros, escravos, e outros fluxos migratórios ${ }^{1}$. No entanto, a participação dos indígenas nos contatos, tratados, conflitos e guerras ainda é pouco retratada e parte das experiências vividas por eles permanece invisibilizada. Assim, o que realmente importa aqui é mostrar um pouco mais sobre as vivências dos índios guaranis durante o século XVIII e principalmente o XIX, período em que se sabe pouco ou quase nada sobre suas histórias. Para aqueles que nasceram, habitaram, estudaram, guerrearam, morreram em São Nicolau do Rio Pardo, parte de suas experiências se deu através dos usos que fizeram daquele importante espaço territorial. A aldeia permaneceu um território eminentemente indígena, entre outros interesses, graças aos seus esforços e estratégias.

\footnotetext{
${ }^{1}$ Não é relevante citar aqui todos os estudos históricos realizados sobre as diversas pessoas e culturas que ocuparam o território em questão. Basta salientar o fato de que as histórias de algumas personagens são mais conhecidas do que as de outras.
} 
É importante destacar que, se por um lado, as experiências dos índios guaranis, sobretudo durante o período provincial, são pouco retratadas; por outro, alguns trabalhos em história vêm demonstrando a enorme multiplicidade de contextos em que indígenas de diversas etnias, lugares e épocas estiveram inseridos. Novos estudos sobre suas histórias nas Américas têm surgido há cerca de 40 anos. A partir da década de 1970, tais estudos foram estimulados por mudanças na noção dos direitos indígenas enquanto direitos históricos, principalmente direitos territoriais. Essas reconfigurações também são oriundas das demandas dos próprios índios e provocaram além de inovações práticas, a ruptura de paradigmas teóricos. É preciso sublinhar, entretanto, que os estudos sobre os indígenas na América espanhola se sobressaíram em comparação aos estudos sobre os indígenas na América portuguesa. Há cerca de quinze anos, era notório o pouco interesse dos historiadores brasileiros em relação a um tema tão importante para entender a História do Brasil. Mas esse cenário parece ser um pouco distinto do atual. Alguns trabalhos que foram produzidos durante a última década ${ }^{2}$ contribuíram para ampliar o debate entre a história e a antropologia. Assim, se antes da década de 1970, os índios eram vistos no debate historiográfico como pertencentes a um passado distante, cujos referenciais históricos eram exclusivamente os avanços e as conquistas européias; com os novos estudos eles são vistos como agentes que atuaram na construção da história da América ${ }^{3}$.

Desse modo, a partir da década de 1970, ao lado do que pode ser chamado de nova história indígena, surgiu um renovado discurso historiográfico sobre os índios e novos enfoques analíticos para uma categoria que, durante muito tempo, foi deixada à margem: a categoria de "índio colonial" . Este passou a ser visto como um ator social que participou do longo processo de construção dos estados e impérios. Essa mudança de perspectiva teórica

\footnotetext{
${ }^{2}$ MONTEIRO, John Manuel. Negros da terra: índios e bandeirantes nas origens de São Paulo. São Paulo: Companhia das Letras, 1994; VAINFAS, Ronaldo. A heresia dos índios: catolicismo e rebeldia no Brasil Colonial. São Paulo, Companhia das Letras, 1995; SAMPAIO, Patrícia Maria Melo. Espelhos partidos. Etnia, Legislação e Desigualdade na Colônia: Sertões do Grão-Pará, c. 1755 - c.1823. Tese de Doutorado apresentada ao Programa de Pós-Graduação em História da Universidade Federal Fluminense, Niterói, 2001; ALMEIDA, Maria Regina Celestino de. Metamorfoses indígenas: identidade e cultura nas aldeias coloniais do Rio de Janeiro. Rio de Janeiro: Arquivo Nacional, 2003; CARVALHO, Jr. Almir Diniz de. Índios cristãos: a conversão dos gentios na Amazônia portuguesa (1653-1769). Campinas, SP, 2005 (Tese de doutorado), para citar somente alguns desses novos trabalhos.

${ }^{3}$ RUSSELL-WOOD, A. J.R. Um mundo em movimento: os portugueses na África, Ásia e América (14151808). Lisboa: Difel, 1998.

${ }^{4}$ SPALDING, Karen. De índio a campesino: cambios en la estructura social del Peru colonial. Lima: Instituto de Estudios Peruanos, 1974.
} 
e discursiva reviu a posição do indígena e sua participação ativa nos processos históricos, e, de meros coadjuvantes ou figurantes, eles passaram a ocupar um papel de protagonistas ao lado daqueles que sempre estiveram em destaque nas cenas históricas, a saber, os 'conquistadores' estrangeiros. Isso também decorre de pesquisas realizadas por outros autores sobre os chamados setores 'subalternos', através das quais, ao longo dos últimos anos, a historiografia brasileira tem buscado inserir grupos sociais antes preteridos nos estudos históricos ${ }^{5}$. Assim, buscou-se incorporar novas abordagens sobre assuntos relativos à escravidão, inquisição, relações de gênero, entre outros. Além disso, tem havido um avanço nos métodos historiográficos com perspectivas oriundas de outras áreas do conhecimento como a antropologia, a psicologia e a lingüística.

Das discussões teóricas estabelecidas entre a história e a antropologia, sobretudo no que concerne aos conceitos de etnicidade e cultura, surgiu o método etnohistórico. Esse método tem permitido analisar as relações estabelecidas no contexto colonial e imperial de modo a transpor a barreira dual, estática e simplista entre os luso-brasileiros e os indígenas. Através da problematização de explicações tradicionais tem sido possível interelacionar histórias construídas a partir de diferentes ações e romper com a idéia de exclusão presente na interpretação de conceitos como aculturação e resistência, complexificando as situações de contato para além das dinâmicas étnicas. De acordo com as novas correntes da etnohistória, os empréstimos e as reformulações culturais e identitárias não devem ser tratadas como algo que, invariavelmente, provoca o desaparecimento do indígena ou da essência que supostamente constitui sua cultura ${ }^{6}$. O processo de construção de identidades culturais não pode ser visto somente como um embate entre dominantes e dominados, afinal, existem trocas culturais que situam novas realidades sociais. Nesse sentido, o trabalho de Natan Wachtel ${ }^{7}$ deu uma grande contribuição aos estudos antropológicos e históricos. Entretanto, em sua obra, o termo aculturação concebia o contato com o

\footnotetext{
${ }^{5}$ DAVIS, Natalie Zemon. Nas margens. (trad.) São Paulo, Cia. das Letras, 1997; GINZBURG, Carlo. $O$ Queijo e os Vermes. (trad.) São Paulo, Cia. das Letras, 1987. PERROT, Michelle. Os Excluídos da História. (trad.) Rio de Janeiro, Paz e Terra, 1988; THOMPSON, E. P. Costumes em Comum. (trad.) São Paulo, Cia. das Letras, 1998.

${ }^{6}$ ROJAS, José Luis de. La etnohistória de América: los indígenas, protagonistas de su historia. [Seleccionado por Guillermo Wilde]. Buenos Aires, SB, 2008.

${ }^{7}$ WACHTEL, Nathan. La vision des vaincus. Les indiens du Péru devant la Conquête Espagnole 1530-1570. Gallimard, Paris, 1971.
} 
‘dominador estrangeiro', no caso da situação colonial, como um evento que intervinha e ameaçava a tradição do 'dominado'. Esse encontro provocava formas de recusa de imposições por parte dos indígenas, ou formas de adaptação a elas. No primeiro caso, se trataria de aculturação imposta; no segundo, de uma aculturação livremente aceita, ou espontânea, como o próprio autor nomeou ${ }^{8}$. Wachtel elaborou uma teoria explicativa para dar conta dos mecanismos que estavam em jogo nos fenômenos de empréstimo cultural e inovação técnica. Contudo, essa teoria sobre aculturação não está mais na ordem do dia, embora tenha sido a partir desses apontamentos que se avançou na questão e foi possível outro entendimento sobre o processo histórico dos contatos. Segundo Guillaume Boccara ${ }^{9}$ :

El movimiento de renacimento indigena, las luchas alrededor de la definición de cultura, las críticas posmodernas a los modelos estructuralista y marxista, así como también la puesta en tela de juicio del paradigma estatal y nacional en un mundo desde ahora vivido y conceptualizado como 'globalizado'contribuyeron de manera crucial a la transformación de las perspectivas de estudio en antropologia historica durante las dos últimas décadas.

Pode-se dizer que com as trocas interdisciplinares que vêm ocorrendo entre centros acadêmicos nacionais e internacionais, as populações indígenas têm aos poucos ocupado um espaço renovado em nossa historiografia. Abordagens com aproximações entre história e antropologia têm promovido debates profícuos ao problematizarem conceitos e perspectivas teóricas. De acordo com Maria Regina Celestino de Almeida, "o resultado tem sido o desenvolvimento de pesquisas interdisciplinares que tendem a valorizar as atuações dos índios como importantes variáveis para a compreensão dos processos históricos nos quais se inserem" 10 .

\footnotetext{
${ }^{8}$ IDEM. "A aculturação", in História: novos problemas. LE GOFF, Jacques \& NORA, Pierre. (org.). Rio de Janeiro: Francisco Alves, 1995, p. 113-129.

${ }^{9}$ BOCCARA, Guillaume. Memoria Americana. Cuadernos de Etnohistoria. "Génesis y estructura de los complejos fronterizos euro-indígenas, repensando los márgenes americanos a partir (y más allá) de la obra de Nathan Wachtel". Buenos Aires. Número 13. 2005, p. 30.

10 ALMEIDA, Maria Regina Celestino de. "Apresentação" in Os índios na História: abordagens interdisciplinares, Revista Tempo, Rio de Janeiro, $\mathrm{n}^{\circ} 23$, vol. 12, p. 1-4, Julho de 2007. Disponível em: http://www.historia.uff.br/tempo/artigos dossie/v12n23a01.pdf.
} 
Assim, estudos mais recentes realizados sobre a temática indígena na historiografia regional, consideram que as estratégias usadas pelos índios fazem parte de um processo no qual eles também puderam agir ${ }^{11}$. Alguns trabalhos enfocaram a ação indígena através da análise de documentos produzidos por eles próprios ${ }^{12}$. Apesar de terem sua trajetória condicionada aos ditames do colonizador, os indígenas conseguiram tecer suas redes sociais e, por conseguinte, suas próprias histórias. Nesse sentido, Elisa Garcia, analisando 'as diversas formas de ser índio no extremo sul da América portuguesa' entre os anos de 1750 e 1820, entende que "não havia uma única maneira de viver para as pessoas assim designadas no contexto estudado. Esta categoria trazia em si limites e possibilidades e foi através da conjugação entre as situações vividas e os seus próprios interesses que os índios ponderavam sobre os rumos a serem tomados" ${ }^{13}$. Bruna Sirtori percebe que, mesmo regidos pela lógica de funcionamento da sociedade colonial, os índios da aldeia dos Anjos (atual cidade de Gravataí-RS) conseguiram se inserir socialmente dentro de um núcleo comunitário através das redes de compadrio ${ }^{14}$.

Apesar desses avanços inquestionáveis, muitas histórias sobre os índios guaranis que viveram no século XIX permanecem invisibilizadas. As pesquisas históricas sobre eles costumam eleger como recortes temporais os séculos XVI, XVII e XVIII e abordam aspectos genéricos ${ }^{15}$. Não obstante tais contribuições historiográficas sejam válidas,

${ }^{11}$ GARCIA, Elisa Frühauf. A integração das populações indígenas nos povoados coloniais no Rio Grande de São Pedro: legislação, etnicidade e trabalho. Dissertação de Mestrado apresentada ao programa de PósGraduação em História da Universidade Federal Fluminense, Niterói, 2003; NEUMANN, Eduardo Santos. O trabalho guarani missioneiro no rio da Prata colonial, 1640-1750. Porto Alegre: Martins livreiro, 1996; , "Fronteira e identidade: confrontos luso-guarani na Banda Oriental 1680-1757", Revista Complutense de História da América. Madri, 2000. N.26; _ , "Mientras volaban correos por los pueblos: autogoverno e práticas letradas nas Missões Guarani - século XVIII", Horizontes Antropológicos. Porto Alegre, 2004. ano 10, n.22, p.93-119, jul./dez. 2004. Tais trabalhos se referem a períodos anteriores aos da segunda década do século XIX.

${ }^{12}$ NEUMANN, Eduardo Santos. 'Práticas letradas guarani: produção e usos da escrita indígena (séculos XVII e XVIII)'. Tese de Doutorado apresentada pelo programa de Pós-Graduação em História da Universidade Federal do Rio de Janeiro, 2005.

${ }^{13}$ GARCIA, Elisa Frühauf. As diversas formas de ser do índio: políticas indígenas e políticas indigenistas no extremo sul da América. Rio de Janeiro: Arquivo Nacional, 2009, p. 292-293.

${ }^{14}$ SIRTORI, Bruna. Entre a cruz, a espada, a senzala e a aldeia. Hierarquias sociais em uma área periférica do Antigo Regime (1765-1784). Dissertação de mestrado apresentada ao Programa de Pós-graduação em História Social do Instituto de Filosofia e Ciências Sociais da Universidade Federal do Rio de Janeiro, Rio de Janeiro, 2008.

${ }^{15}$ Não há publicações na historiografia regional que tratem das histórias dos índios guaranis na Província de São Pedro. Também não localizei referência historiográfica sobre índios guaranis no Brasil oitocentista. A maior parte das publicações sobre os povos guarani-missioneiros enfoca a segunda metade do século XVIII. FLORES, Moacyr. 'A transmigração dos guaranis para a Aldeia de Nossa Senhora dos Anjos' in: Gravataí: 
geralmente os motes dados à história indígena são cronológicos e factuais ${ }^{16}$, ou tratam da resistência cultural nos aldeamentos. Tudo isso pode levar a falsas e perigosas impressões. Uma delas é a de que, em virtude dos séculos de contatos estabelecidos, os guaranis não teriam sido capazes de sobreviver física e culturalmente ao advento do século XIX, quando já estariam misturados à sociedade nacional, não sendo mais possível diferenciá-los. O resultado de tal 'mistura' teria levado ao seu desaparecimento enquanto etnia. O que está em jogo aqui é o que se espera ou se exige, mais uma vez, dos índios e suas histórias: uma pureza étnica e cultural, cuja perda ocasionaria seu desaparecimento ou a aculturação. No entanto, Serge Gruzinski chama a atenção para a complexidade que envolve o conceito de mestiçagem e estende sua crítica aos arcaísmos, à valorização de tradições tidas como autênticas e a pouca ênfase dada aos processos de recomposição permanente e seus efeitos $^{17}$. Outra das impressões é a hipótese avessa àquela, muitas vezes aceita, de que após a expulsão dos jesuítas e durante o período imperial os guaranis teriam se ‘escondido’ na mata, sem estabelecer qualquer contato com os núcleos urbanos das vilas e aldeamentos mantendo sua cultura a salvo do convívio com elementos externos. Esses seriam os principais motivos pelos quais supostamente quase nada teria sido falado, sabido ou escrito sobre eles durante o oitocentos, impossibilitando o trabalho dos historiadores em tempos posteriores. Entretanto, a história de longa duração acerca dos múltiplos contatos que os guaranis estabeleceram não pode servir como motivo para sua invisibilização no século XIX, como se o passar do tempo fosse responsável pela perda de suas identidades étnicas. Ao contrário, suas diferentes ações ao longo dos séculos servem para mostrar sua capacidade de lidar com os eventos e com as mudanças e usá-los nos processos de reelaborações identitárias. Além disso, a quantidade e o conteúdo das fontes históricas

do êxodo à composição étnica. Gravataí, Secretaria Municipal de Educação e Cultura, 1990; NEIS, Ruben. "A Aldeia de Nossa Senhora dos Anjos" in: Gravataí: história e cultura. Gravataí, Secretaria Municipal, 1987; LANGER, Paulo Protásio. A Aldeia de Nossa Senhora dos Anjos: A resistência do Guarani-Missioneiro ao processo de dominação do sistema colonial luso (1762-1798). Porto Alegre: EST, 1997. , Os Guarani-Missioneiros e o colonialismo luso no Brasil meridional, projetos civilizatórios e faces da identidade étnica (1750-1798). Porto Alegre, 2005; PORTO, Aurélio. História das Missões Orientais do Uruguai. Rio de Janeiro: Ministério da Educação e Saúde, 1943; SANTOS, Corcino de Medeiros dos. "O índio e a civilização cristã ocidental: a aldeia de Nossa Senhora dos Anjos de Gravataí" in: Gravataí: do êxodo à composição étnica. Gravataí, Secretaria Municipal de Educação e Cultura, 1990.

${ }^{16}$ RUBERT, Arlindo. História da Igreja no Rio Grande do Sul: época colonial (1626/1822). Porto Alegre: EDIPUCRS, 1994.

17 GRUZINSKI, Serge. El pensamiento mestizo: cultura amerindia y civilización del Renacimiento. Barcelona, Ediciones Paidós Ibérica, 2007. 
escritas sobre eles durante o século XIX fazem essas impressões caírem por terra ${ }^{18}$, contrariando as hipóteses sobre o desaparecimento dos guaranis e a inexistência dos contatos entre eles e a sociedade nacional nos oitocentos.

Para analisar atos de resistência atrelados aos processos de troca, negociação e conflito dos quais os guaranis participaram é necessário que os enfoques espaciais e temporais dados à história indígena dialoguem entre $\mathrm{si}^{19}$. Mas, além disso, é preciso que o conjunto das relações sociais possa contemplar as múltiplas facetas das ações e reações indígenas dando visibilidade e sentido aos seus modos de pensar e agir. Desse modo, procuro demonstrar ao longo das páginas que se seguem que os índios de São Nicolau do Rio Pardo não foram seres à parte. Eles não estiveram isolados nas matas ou presos aos aldeamentos durante o século XIX, e nem antes disso. Não agiram sempre do mesmo modo. Nem todos possuíram necessariamente as mesmas histórias, apesar de estas estarem interligadas pelo passado, cultura, experiências e identidades compartilhadas. Como todos os demais agentes históricos envolvidos em cada contexto, estabeleceram diferentes maneiras de se relacionar socialmente, tanto no território da aldeia, como fora dele. Suas ações e seus modos de ver e pensar sobre objetos, pessoas e acontecimentos fizeram parte da formação, manutenção e extinção do aldeamento. Assim, o que se pretende oferecer ao leitor ao longo do texto é a visão de que há uma grande diversidade de histórias que se passaram naquele território entre os anos de 1757 e a década de 1860. Estes recortes temporais são importantes, embora não confiram ao presente trabalho uma preocupação demasiada com a precisão cronológica das datas de fundação e extinção do aldeamento de São Nicolau do Rio Pardo. Ele possui histórias cujas redes complexas de significados ultrapassam suas fronteiras territoriais e o período compreendido entre sua formação e extinção. O contingente populacional que o compôs em meados do século XVIII possuía uma história pregressa de alianças e conflitos estabelecidos com jesuítas, portugueses e

${ }^{18}$ FAVRE, Oscar Padrón. Ocaso de un pueblo índio: historia del éxodo guaraní-missionero al Uruguay, Bella Unión, San Borja del Yÿ. Durazno, Tierra Adentro, 2009 [1 $1^{\text {a }}$ edição 1996]. Essa pesquisa é sobre dois aldeamentos indígenas, o de Bella Unión e San Borja del Ÿ̈, fundados em virtude do êxodo guaranimissioneiro para o Uruguai em 1828. GARCIA, Elisa Frühauf. Op. Cit. 2009. A autora aborda o aldeamento de São Nicolau do Rio Pardo e outras histórias envolvendo índios guaranis nas duas primeiras décadas do século XIX.

${ }^{19}$ LANGER, Paulo Protásio. A Aldeia de Nossa Senhora dos Anjos: A resistência do Guarani-Missioneiro ao processo de dominação do sistema colonial luso (1762-1798). Porto Alegre: EST, 1997. IDEM, Os GuaraniMissioneiros e o colonialismo luso no Brasil meridional, projetos civilizatórios e faces da identidade étnica (1750-1798). Porto Alegre, 2005. 
espanhóis. No XIX, uma das leis, a do ano de 1862, que autorizava e reiterava sua extinção e o loteamento de suas terras para 'colonos' e 'nacionais' não levou ao completo e imediato esvaziamento do mesmo. As disputas pelas terras do aldeamento se intensificaram a partir de 1820, mas a presença de guaranis no local aparece em uma fonte histórica da década de 1890. Esses dados indicam que outros contatos, conflitos e relações sociais continuaram a ocorrer ao longo de todo o século XIX.

Mas como perceber as ações e os modos de ver e pensar dos índios em fontes históricas, que em sua grande maioria não foram escritas por eles? Indubitavelmente, tratase de um grande desafio para os historiadores. Mas a partir da análise das fontes atenta às pistas que esses agentes direta ou indiretamente deixaram sobre seu passado, é possível recuperar aspectos importantes sobre suas histórias. Presente em diferentes tipos de fontes, as informações sobre eles estão espalhadas em livros, documentos e manuscritos de bibliotecas, arquivos, museus e institutos históricos. Esta pesquisa está baseada principalmente na análise de fontes documentais primárias existentes em alguns arquivos brasileiros e estrangeiros ${ }^{20}$. Através da análise dessas fontes, procura-se estabelecer alguns elementos que permitam abordar aspectos sobre os modos indígenas e indigenistas de agir e como essas ações foram recebidas e postas em prática, sobretudo, pelos índios partícipes desse processo de organização e construção social. Alguns relatos e comentários produzidos sobre os índios guaranis também fazem parte da pesquisa ${ }^{21}$. O historiador Carlo Ginzburg, comparando os fios que compõem uma pesquisa aos que compõem um tapete avalia que 22

\footnotetext{
${ }^{20}$ São eles: Archivo General de Simancas (AGS), Arquivo Histórico do Rio Grande do Sul (AHRS), Arquivo Histórico do Município de Porto Alegre (AHPA, conhecido também como Arquivo Histórico Moysés Vellinho) e Arquivo Histórico do Município de Rio Pardo (AHMRP). Essas são as instituições de pesquisa de onde provém a maior parte das fontes utilizadas neste estudo, embora haja também documentos oriundos do Archivo General de la Nación (AGN - Buenos Aires), da Biblioteca Nacional do Rio de Janeiro (BNRJ), Biblioteca Nacional de Lisboa (BNL), Arquivo Nacional do Rio de Janeiro (ANRJ) e do Instituto Histórico e Geográfico do Rio Grande do Sul (IHGRGS).

21 AVÉ-LALLEMANT, Robert. Viagem pela Província do Rio Grande do Sul (1858). Belo Horizonte: Itatiaia, 1980; NIMUENDAJÚ, Curt Unkel. As lendas da criação e destruição do mundo como fundamentos da religião dos Apapocúva-Guarani. São Paulo: Hucitec/Edusp, 1987, p. 27-71; SAINT-HILAIRE, Auguste. Viagem ao Rio Grande do Sul (tradução de Adroaldo Mesquita da Costa). Brasília: Senado Federal, Conselho Editorial, 2002.

${ }^{22}$ GINZBURG, Carlo. Mitos, Emblemas, Sinais: morfologia e história. São Paulo: Cia das Letras, 1999, p. 170.
} 
o tapete é o paradigma que chamamos a cada vez, conforme os contextos, de venatório, divinatório, indiciário ou semiótico. Trata-se, como é claro, de adjetivos não-sinônimos que, no entanto, remetem a um modelo epistemológico comum, articulado em disciplinas diferentes, muitas vezes ligadas entre si pelo empréstimo de métodos ou termoschave.

Tal como ele expôs, é possível enxergar nos detalhes o que não é evidente, aproximando e tomando de empréstimo disciplinas e métodos de análise, como é o caso da antropologia e do método etnohistórico neste trabalho. O conteúdo das fontes permite conhecer aspectos sobre as idéias e os pensamentos de diversos atores sociais e de como, em algumas ocasiões, puderam colocá-los em prática. Trata-se de relatos de viagem e experiências, correspondências, requerimentos, editais, ofícios e circulares. A natureza de caráter e conteúdo específico de cada tipo de documento requer, certamente, maneiras distintas de abordagem. Apesar dessas especificidades, todos eles oferecem indicativos importantes sobre as relações estabelecidas entre os indígenas e os demais agentes de diferentes segmentos sociais. Através da análise desse conjunto documental é possível perceber as dinâmicas e os jogos de poder em que se deram as relações pautadas pelas demandas sociais e políticas da Província em relação ao aldeamento de São Nicolau do Rio Pardo, e o posicionamento dos índios diante das mesmas. Dessa forma, a problemática que guia a pesquisa está presente nessas fontes, no que tange à relevância histórica do território de São Nicolau do Rio Pardo e das pessoas que o compuseram, com as quais outras tantas se relacionaram. A longevidade de São Nicolau do Rio Pardo perpassa boa parte do século XVIII e mais da metade do século XIX, de maneira que o estudo das dinâmicas sociais e políticas em que os índios estiveram envolvidos permite contemplar as experiências pelas quais vários personagens históricos passaram.

O capítulo 1 apresenta questões relevantes acerca dos processos históricos vividos pelos guaranis de São Nicolau do Rio Pardo levando em conta alguns dos discursos que foram produzidos e modificados por tais histórias e seus agentes. Os discursos de políticos sobre eles parecem ser contraditórios, mas mostram a dificuldade daqueles que os escreveram em lidar com a política indígena e com a política indigenista. Diferentes, embora marcados por algumas semelhanças, os discursos dos religiosos demonstram o desafio que a prática da catequese impôs a eles e aos índios. Alguns religiosos e indígenas a 
aceitaram, outros negaram, outros ainda vilipendiaram. Houve razões bastante distintas para tais ações, deixando transparecer que as experiências coletivas e individuais dos índios, dos políticos e religiosos geraram conflitos e alianças importantes nas histórias dessas personagens.

O segundo capítulo enfoca alguns aspectos sobre a formação do aldeamento de São Nicolau do Rio Pardo e informações inéditas sobre índios guaranis e outros sujeitos históricos que o compuseram em sua fase inicial, em meados do século XVIII. Posteriormente, oferece evidências sobre outras experiências de contato ocorridas entre índios guaranis durante o século XIX e sua atuação diante das mesmas. Ele representa uma ponte entre os séculos XVIII e XIX ao unir e contrapor aspectos do período da formação do aldeamento e outros que remetem à sua longevidade nos oitocentos. Esses dois capítulos iniciais também expõem para o leitor maneiras de abordar as fontes, assim como algumas referências sobre método e teoria que guiaram o tratamento dado às mesmas ao longo dos capítulos, ressaltando os objetivos do trabalho.

O capítulo 3 traz elementos importantes sobre as relações dos guaranis com o território do aldeamento. Eles estabeleceram contatos com autoridades provinciais, indígenas e não-indígenas de outros lugares da Província de São Pedro, e, até mesmo de fora dela. Isso envolve também novas relações históricas que os guaranis criaram com esferas que não lhes eram estranhas, como por exemplo, as esferas política, jurídica, econômica e 'educacional'; referindo-me respectivamente às alianças e conflitos com autoridades e elite locais, aos ofícios e petições encaminhadas por eles para reaver terras e direitos coletivos, à sua participação em atividades comercias, principalmente a erva-mate, e por fim as redes sociais acionadas e as experiências vividas através do ensino ministrado na escola do aldeamento, exclusivo para meninos guaranis.

O último capítulo mostra um pouco mais sobre a vivência dos guaranis fora do aldeamento através de sua participação em conflitos bélicos que marcaram a história deles e do Brasil: a batalha de Tacuarembó (1820), a Guerra dos Farrapos (1835-1845) e a Guerra do Paraguai (1865-1870). Suas atuações nas guerras geraram registros sobre a importância de seu desempenho nas frentes de batalha e do uso de suas habilidades militares nos conflitos. Reconhecidas e desmerecidas, lembradas e esquecidas, exaltadas e desdenhadas, 
a presença e as performances dos guaranis nesses eventos dão a ver a necessidade do uso da mão-de-obra indígena em tempos de guerras na Província de São Pedro. Revelam beleza na capacidade dos índios de se relacionarem com o tempo e os acontecimentos e fazer parte deles, algumas vezes a seu modo, em seus próprios termos.

No que se refere às formalidades, esclareço que é necessário não confundir a redução jesuítica de São Nicolau, fundada em 1626, em território espanhol, com o aldeamento de São Nicolau do Rio Pardo ${ }^{23}$, fundado em 1757, em território lusitano. A ortografia das fontes históricas foi atualizada para facilitar a leitura. Quanto à grafia dos etnônimos, a referência é feita com letra minúscula acompanhando as variações das formas adjetivadas e substantivadas. Não fiz distinção entre os termos índios e indígenas. Optei por não traduzir livremente as citações feitas em língua estrangeira.

${ }^{23}$ A menção a Rio Pardo, evidentemente, já difere o aldeamento da redução de São Nicolau. 


\section{CAPÍTULO 1 - OS INDÍGENAS NA PROVÍNCIA DE SÃO PEDRO: ENTRE PRÁTICAS E DISCURSOS}

"Afirmando ainda que todas as doutrinas, políticas e práticas baseadas na superioridade de determinados povos ou indivíduos, ou que a defendem alegando razões de origem nacional ou diferenças raciais, religiosas, étnicas ou culturais, são racistas, cientificamente falsas, juridicamente inválidas, moralmente condenáveis e socialmente injustas".

Anexo da Declaração das Nações Unidas sobre os Direitos dos Povos Indígenas em recomendação que figura na resolução 1/2 do Conselho dos Direitos Humanos, de 29 de junho de 2006.

\section{1 - INTRODUÇÃO}

$\mathrm{O}$ estudo realizado por John Monteiro ${ }^{24}$ traz à tona questões importantes a respeito dos processos históricos pelos quais indígenas passaram, levando em conta os discursos que foram produzidos sobre tais histórias em tempos posteriores. Através de discursos extraídos dos escritos de alguns colonizadores sobre os indígenas, durante os séculos XVI, XVII e XVIII, ele elucida como as interpretações daqueles discursos adquiriram outros significados ao longo do século XIX. Segundo o historiador ${ }^{25}$ :

\footnotetext{
${ }^{24}$ MONTEIRO, John Manuel. Tupis, tapuias e historiadores. Estudos de história indígena e do indigenismo. Tese apresentada para o concurso de Livre Docência em Antropologia na Universidade Estadual de Campinas, Campinas, 2001.

${ }^{25}$ IDEM, p. 68.
} 
O que se nota nas fontes quinhentistas e seiscentistas é precisamente a tensão entre a busca de uma unidade Tupi - afirmada no contraste com os Tapuia - (...), esta tensão ganhou novos contornos no século XIX, através das releituras que os primeiros historiadores nacionais fizeram dessas mesmas fontes. No entanto, se parte do problema pode ser atribuída às tresleituras de observadores que pouco entendiam da organização social ameríndia, esses relatos também deixam transparecer algo da percepção indígena do processo de "etnificação.

Conforme John Monteiro chama a atenção, a relação entre "Tupis, Tapuias e historiadores" oscila conforme o tempo e de acordo com a ação dos próprios indígenas em determinadas situações. Desse modo, é preciso considerar os contextos gerais e específicos das relações sociais estabelecidas entre os agentes indígenas e não-indígenas. No caso deste estudo, não se pode perder de vista que a Província de São Pedro, embora certamente tivesse suas especificidades em relação às demais, inseria-se numa conjuntura mais ampla de formação do estado nacional brasileiro. Assim, há que se considerar que o século XIX foi um período de grandes transformações e contradições políticas. As tensões decorrentes da mudança de regimes políticos e os renovados propósitos econômicos oriundos da ascensão do capitalismo refletiam as disparidades da época. No Oitocentos, a política indigenista, assim como a política de 'povoamento' do Brasil, foi marcada pela preocupação com a questão da terra como principal meio de erigir a nação. Com a criação do Estado nacional brasileiro, tornou-se necessário construir uma memória nacional que reunisse a sociedade em torno de novas identidades históricas e culturais. Nesse cenário, os discursos históricos e identitários de políticos e intelectuais sobre os índios se contradiziam e evidenciavam as disputas presentes na elaboração da história, da memória coletiva e da identidade da nação ${ }^{26}$.

Enquanto o jovem Estado nacional brasileiro buscava auto-estima e símbolos identitários que incorporassem grupos étnicos presentes em seu território, algumas comunidades indígenas lutavam para continuar existindo como uma coletividade em meio às políticas assimilacionistas e de extermínio. A Província de São Pedro também participou da elaboração de discursos históricos, políticos e identitários sobre os índios que ocuparam

\footnotetext{
${ }^{26}$ ALMEIDA, Maria Regina Celestino de. "Comunidades indígenas e Estado nacional: histórias, memórias e identidades em construção (Rio de Janeiro e México - séculos XVIII e XIX)", in ABREU, Martha, SOIHET, Rachel, GONTIJO, Rebeca (org.). Cultura política e leituras do passado: historiografia e ensino de história. Rio de Janeiro: Civilização Brasileira, 2007, pg. 192- 212.
} 
seu território. Eles expressam idéias e opiniões acerca dos índios com os quais políticos e religiosos se relacionaram e revelam que houve diferentes tipos e trocas de experiências entre essas pessoas.

Os discursos produzidos sobre os índios na Província de São Pedro foram elaborados e veiculados por diferentes agentes sociais e, às vezes, parecem distintos e contraditórios. Ainda que o sejam, eles se apresentam como um reflexo das experiências históricas vividas por aqueles agentes. Logo, é preciso situar o contexto de produção desses discursos para tentar compreendê-los, assim como é preciso levar em conta que eles mudaram ao longo do tempo. Se hoje, os discursos historiográficos sobre os índios tendem a ver como protagonistas históricos as parcialidades e os indivíduos; durante o século XIX, os historiadores que inauguravam a ciência histórica, construíram um discurso que restringiu todos os grupos indígenas a dois grandes blocos estanques. Tal discurso via nos Tupis do século XVI, a gênese daquilo que foi tido como autenticamente nacional, o índio. A grande contradição estava no fato de ser preciso lidar na prática com um ancestral histórico que as teorias da época comprovaram como 'cientificamente' inferior. A saída encontrada foi veicular a idéia de que existiam no século XIX, duas categorias de índios: o índio Tupi, um herói ancestral admirado, que fazia parte de um passado nobre e distante; e o índio Tapuia, que fazia parte do presente, era desprezado e devia ser combatido ${ }^{27}$. Afinal, a nação brasileira não poderia ser uma civilização reconhecida se ainda mantivesse habitantes selvagens em seu território. Mas como esses discursos teriam influenciado as histórias dos índios na Província de São Pedro? Serão necessários muitos estudos etnohistóricos para esboçar uma resposta a essa pergunta. A proposta deste capítulo é oferecer alguns apontamentos sobre essa questão, enfocando as relações sociais e de poder estabelecidas pelos índios de São Nicolau do Rio Pardo com os demais agentes sociais a partir dos discursos políticos e eclesiásticos produzidos sobre eles ao longo do século XIX. Para tanto, é preciso perceber que, mesmo estando afastada da capital do Império, portanto, longe dos gabinetes centrais da política e da ciência, conforme apontado por John

\footnotetext{
${ }^{27}$ Para maiores detalhes sobre esse debate acerca das noções sobre Tupi e Tapuia ver MONTEIRO, John Manuel, Op. Cit. 2001, com destaque para o Capítulo 8: As "Raças" Indígenas no Pensamento Brasileiro, p. 140-179.
} 
Monteiro $^{28}$, a Província de São Pedro recebia suas influências, e as adaptava aos seus próprios gabinetes e sertões. De acordo com o mesmo autor, os protagonistas da construção dos ideais da nova nação eram desafiados por duas ordens de questões que diziam respeito ao destino das populações indígenas. Uma, de caráter científico e antropológico, antagonizava princípios universais do Iluminismo à ciência da desigualdade, pautada em noções de raça. A outra, de cunho político, colocava em choque a necessidade de valorizar as 'origens' indígenas da nação brasileira e o olhar negativo sobre o índio da atualidade. Era preciso, minimamente, conciliar a mestiçagem biológica e cultural da sociedade com a civilização da nação brasileira ${ }^{29}$ :

$o$ resultante diálogo entre o pensamento científico e a política indigenista produziu, ao longo do século XIX e, de certo modo, do XX, imagens e opiniões conflitantes, ora promovendo a inclusão das populações indígenas no projeto da nação, ora sancionando sua exclusão. Se ambas estas questões circulavam basicamente no âmbito dos gabinetes científicos e dos gabinetes políticos, elas esbarravam, o tempo todo, nas práticas e percepções dos protagonistas dos encontros e confrontos entre índios e não índios em remotos sertões.

As palavras de John Monteiro dão a ver que os discursos produzidos nos gabinetes políticos e eclesiásticos sobre os indígenas precisam ser contextualizados historicamente. Utilizarei os Relatórios de Presidente da Província de São Pedro ${ }^{30}$ entre os anos de 1832 e 1863, e a obra intitulada "Comentário Eclesiástico do Rio Grande de São Pedro do Sul desde 1737" 31, conhecida como "O Ementário", para contextualizar práticas e discursos de indígenas, políticos e religiosos na Província de São Pedro.

É preciso salientar que o título deste capítulo não se refere especificamente aos índios guaranis de São Nicolau do Rio Pardo, e sim aos índios na Província de modo geral. Tal fato se deu mediante a leitura e análise das fontes históricas e à percepção de que é

\footnotetext{
${ }^{28}$ MONTEIRO, John Manuel. Op. Cit. 2001. Capitulo 7, Entre o Gabinete e o Sertão: Projetos Civilizatórios, Inclusão e Exclusão dos Índios no Brasil Imperial, p. 129-169.

29 IDEM. Op. Cit., 2001, pg. 131.

${ }^{30}$ AHPA. Relatórios de Presidente da Província de São Pedro do Rio Grande do Sul, Catequese e Civilização dos Índios entre 1832, 1857, 1859, 1861, 1862, 1863.

31 IHGRGS. DIAS LOPES, Vicente Zeferino. "Comentário Eclesiástico do Rio Grande de São Pedro do Sul desde 1737’. Cópia datilografada. Agradeço a Fábio Kühn por ter cedido uma cópia desse documento.
} 
necessário deixar claro ao leitor as diferenças existentes nos discursos dos padres missionários e dos políticos em relação à aplicação das políticas indigenistas para os índios guaranis e para outras parcialidades como os coroados, como se fará notar adiante.

\section{2 - PRÁTICAS INDÍGENAS NOS DISCURSOS DE POLÍTICOS}

Pode parecer estranho, mas nos relatórios de presidente da Província havia discussões sobre o extermínio dos índios e de seus aldeamentos na parte intitulada Catequese e Civilização. Apesar disso, tais relatórios indicam que houve um esforço, às vezes paradoxal e difícil de entender, por parte das autoridades provinciais, para civilizar os índios e torná-los 'amigos'. Sentimentos de repúdio e admiração estão presentes nessa documentação oficial. Em outubro de 1832, Luis Alves Leite de Oliveira Bello escreveu no relatório da Província ${ }^{32}$ :

Pouco difere do ano passado o estado presente dos aldeamentos. Mas não faltarão esforços para dar algum incremento à sua população, e comodidade. É esse um dos serviços provinciais, a que, na minha opinião, se deve ligar muito interesse, não tanto pela conveniência de aditar-se a população da Província as hordas errantes, e selvagens de nossos colonos naturais, como pela necessidade de desinfetar as matas, e de converter em amigos, e membros úteis da sociedade os mais formidáveis inimigos de nossas populações centrais. Desistir do empenho em que já algumas somas se tem gasto pela pouca importância do resultado, seria perder o que se tem ganho, e perpetuar a luta desumana do cidadão com o selvagem.

Trata-se de um discurso produzido num gabinete político, diferente de um discurso produzido nos gabinetes científicos situados na capital do Império. Desse modo, é interessante observar que, ao contrário dos discursos predominantemente difundidos pelos gabinetes científicos do Instituto Histórico e Geográfico Brasileiro (IHGB), neste caso, os

\footnotetext{
${ }^{32}$ AHPA. Relatório do Vice-Presidente da Província de São Pedro do Rio Grande do Sul, Luiz Alves Leite de Oliveira Bello, na abertura da Assembléia Legislativa Provincial, 01 de outubro de 1832.
} 
índios não são admirados por fazerem parte de um passado remoto, como os Tupis ${ }^{33}$. O vice-presidente da Província se refere aos índios do presente, os Tapuias, e os admira não pelo fato de eles serem ex-óticos, ou não-vistos, mas pelo motivo oposto, visto que é o fato de ouvir sobre os índios, saber sobre ou ter que se confrontar com assuntos referentes a eles, quem sabe até mesmo conhecê-los, é que o fizeram pensar que eles eram "os mais formidáveis inimigos" e que é desumana a luta do cidadão com o selvagem. São as experiências vividas pelo vice-presidente da Província que o fizeram sentir que não eram humanos os atos de força do 'civilizado' contra o 'selvagem'. A contradição presente entre os significados de sentimentos como a humanidade e a civilidade, e atos como os de selvageria são condizentes com a variada gama de pensamentos, experiências e sentimentos vividos pelos protagonistas dessa história. Segundo John Monteiro ${ }^{34}$ :

a tensão entre a simpatia pelos índios, frutos de experiências no sertão, e os pressupostos teóricos sobre a inferioridade e o atraso dos selvagens em referência à civilização se manifestava nos escritos de vários pensadores e políticos do Império.

No mesmo Relatório de Presidente da Província, e desta vez falando especificamente da aldeia de São Nicolau, Luis Alves Leite de Oliveira Bello parece se contradizer em relação aos índios da Província ${ }^{35}$ :

É a mais antiga aldeia da Província. Situada a pouca distância da cidade de Rio Pardo, e reduzida a 273 indivíduos de origem guarani, achase na maior decadência, e não conserva hoje nada, que se assemelhe ao registro das aldeias, a não ser um zeloso e honrado diretor. Os seus habitantes descendem todos de descendentes de indios catequizados. Em verdade, como a antiga Aldeia de Nossa Sra. dos Anjos, no município dessa capital, aquela deverá ser considerada extinta, e convertida em capela curada da freguesia de Rio Pardo, para entrar no registro comum das demais povoações da Província.

\footnotetext{
${ }^{33}$ Menciono a dicotomia entre Tupis e Tapuias tendo como referência a análise feita por John Monteiro ao longo da sua tese de livre docência. MONTEIRO, John Manuel. Op. Cit. 2001.

${ }^{34}$ IDEM. Op. Cit. 2001, p. 152.

${ }^{35}$ AHPA. Relatório do Vice-Presidente da Província de São Pedro do Rio Grande do Sul, Luiz Alves Leite de Oliveira Bello, na abertura da Assembléia Legislativa Provincial, 01 de outubro de 1832.
} 
Já não é possível perceber qualquer simpatia de Luis Bello pelos 'descendentes' de índios catequizados. Entretanto, trata-se de discursos diferentes sobre indígenas diferentes, ambos produzidos pela mesma pessoa e fazendo parte do mesmo relatório anual dos presidentes da Província. Dentro desse discurso político, “os mais formidáveis inimigos do Estado", os selvagens a quem Luis Alves Leite se refere, são os índios coroados. Os "indivíduos de origem guarani”, em cujo aldeamento não conserva nada que se assemelhe ao registro do que foram as aldeias guarani-missioneiras, são os guaranis da aldeia de São Nicolau do Rio Pardo.

Porém, é preciso levar em consideração que o passado dos índios guaranis é diferente do passado dos índios coroados e as ações direcionadas aos aldeamentos são também diferentes. Para o argumento que aqui desenvolvo é necessário relembrar, que os índios guarani-missioneiros das missões orientais do Uruguai estiveram envolvidos em negociações e conflitos, mediante os quais tiveram experiências de alianças e contatos feitos ora com os jesuítas, ora com os portugueses e espanhóis, ora com seus 'compatriotas' brasileiros ao longo dos séculos. Os índios Tupis, enquanto uma categoria inventada dentro dos gabinetes do IHGB, eram vistos como os nobres guerreiros que estabeleceram alianças com os portugueses no passado, inclusive alianças matrimoniais e de parentesco, garantindo aos lusitanos a conquista da terra brasilis. Entretanto, os índios guaranimissioneiros, que possuem um passado de alianças com os portugueses, e por esse motivo se aproximam da categoria de índios Tupi nos discursos historiográficos do IHGB, são de 'carne e osso' e estão presentes na Província de São Pedro durante todo o período imperial. Vale relembrar também que o aldeamento de São Nicolau foi fundado em virtude de uma negociação estabelecida entre os índios guarani-missioneiros e Gomes Freire - o comissário português encarregado das demarcações de fronteira acordadas pelo tratado de Madri - e que, portanto, o passado de alianças com os portugueses não é tão remoto, nem tão fictício como para o caso da categoria inventada pelo IHGB (os Tupis). No relatório de presidente da Província do ano de 1859 , outro político dizia o seguinte ${ }^{36}$ :

\footnotetext{
${ }^{36}$ AHPA. Relatório do Vice-Presidente da Província de São Pedro do Rio Grande do Sul, Joaquim Antão Fernandes Leão, na abertura da Assembléia Legislativa Provincial, 1859.
} 
Não sou dos que acreditam na proficuidade dos meios atualmente empregados para chamar à civilização as tribos errantes, que habitam as nossas florestas, e imprimir-lhes hábitos de vida mais regulares $e$ pacíficos. Em toda parte sentem-se os mesmos embaraços, e atuam as mesmas causas, que explicam o estado pouco satisfatório dos nossos aldeamentos. Sem missionários apostólicos não há catequese possível. Dificultosa se tem tornado a aquisição deles, e sem esperança de consegui-los na proporção das nossas necessidades, confio ainda menos na sorte futura das nossas colônias indígenas.

Já nessa fala, se observa que, inúteis são os meios empregados em toda parte para catequizar e 'civilizar' os índios. A opinião deste político, o conselheiro Joaquim Antão Fernandes Leão está, de certo modo, em consonância com a opinião do arcediago Lopes, como veremos adiante, no tocante à ineficiência de um dos métodos mais utilizados pela Província na civilização dos índios, a catequese. Ambos comentaram a carência de missionários naquele período, por mais que, como vimos, a aquisição de padres não significasse, necessariamente, o suprimento das demandas da catequese na Província. Em 1861, o comendador Patrício Correa da Câmara voltava a ser o responsável pelo relatório da Província e sobre a catequese e a civilização dos índios escreveu ${ }^{37}$ :

Ao falar pela primeira vez desse assunto malfadado para todas as administrações do país, disse eu à Assembléia Provincial que tinha tristes previsões do futuro dos aldeamentos da Província. A ninguém é lícito apressar a marcha providencial dos acontecimentos; entretanto tem-se querido obter das tribos errantes do sertão uma transição demasiado rápida dos seus hábitos de ociosidade, para os penosos trabalhos da agricultura, que em todas as épocas caracterizam um estado social já adiantado: nada se tem conseguido, nada provavelmente se há de conseguir. A própria natureza protesta contra o sistema até hoje aceito. Quantos milhões de indivíduos tem já sucumbido ao peso desses progressos fictícios que se lhes impõe?

Enquanto os indígenas que fizeram parte do aldeamento de São Nicolau do Rio Pardo pareciam buscar manter relações sociais levando em conta o seu passado, e tentando resgatar a importância das alianças estabelecidas ao longo dos últimos cem anos, o comendador Patrício Câmara parecia ter pressa do futuro. Os indígenas demonstravam que

\footnotetext{
${ }^{37}$ AHPA. Relatório do Vice-Presidente da Província de São Pedro do Rio Grande do Sul, Patrício Correa da Câmara, na abertura da Assembléia Legislativa Provincial, 1861.
} 
possuíam uma história e que a conheciam, por exemplo, ao reformar constantemente sua igreja, ou ao enviar requerimentos baseados em direitos e concessões adquiridas no passado, enquanto o comendador tentava negar a possibilidade de continuidade da mesma. Ele considerava a transição dos indígenas da selvageria à civilização demasiadamente lenta, afinal, fazer com que os índios fossem capazes de mudar tão rapidamente era esperar demais deles. Conseguir com que atingissem o que ele considerava ser um estágio social avançado, era quase uma experiência onírica, era um futuro impossível de ser concretizado na realidade vivida pelos índios e, portanto, era um futuro possível de ser vislumbrado apenas no mundo dos sonhos.

A despeito de seu prognóstico nada animador sobre a civilização e o futuro dos índios, o comendador fez uma pergunta capaz de encabular até mesmo o mais insensível e descomprometido dos políticos de todos os tempos: 'quantos milhões de indivíduos tem já sucumbido ao peso desses progressos fictícios que se lhes impõe?'. Nesse discurso político em que se faz presente o confronto entre ficção e realidade não são somente os índios mortos e os progressos do século XIX que transitam entre fronteiras complexas de atos, idéias e sentimentos. As histórias dos protagonistas deste contexto também parecem estar perdidas no tempo. Mas, tais histórias se cruzam no mesmo relatório de presidente de Província. Sem responder à pergunta capciosa e imprevisivelmente atual que havia feito, o comendador passou a tratar especificamente do aldeamento de São Nicolau do Rio Pardo ${ }^{38}$ :

Falarei sobre esse tópico por ser ainda conservado um diretor estipendiado pelos cofres provinciais. Em o último relatório que apresentei, disse o que era realmente este aldeamento, ao qual me parece que pode ser aplicada a disposição do $\$ 8^{\circ}$ do art. 11 da lei $n^{\circ} 1.114$ de 27 de setembro de 1860, e $\$ 4^{o}$ do art. $1^{o}$ do decreto $n^{\circ} 426$ de 24 de julho de 1845 .

Conforme dito anteriormente, esse relatório foi escrito no ano de 1861. Há pouco mais de um século antes disso, em 1757, o aldeamento de São Nicolau era fundado depois do acordo feito entre indígenas guarani-missioneiros e portugueses durante o evento que

\footnotetext{
${ }^{38}$ IDEM.
} 
marcou o modo como as demarcações fronteiriças se estruturariam durante os próximos anos do século XVIII - a Guerra Guaranítica. Em 1757, 1758 e 1759, cem anos antes desses relatórios de políticos terem sido escritos, havia índios estabelecidos em São Nicolau do Rio Pardo e índios que continuavam a chegar e a partir. $\mathrm{O}$ aldeamento recebeu boa parte dos índios e índias vindos dos povos das missões, como veremos no capítulo 2 , assim como foram transferidos contingentes que formaram os demais aldeamentos guarani-missioneiros fundados em território português. São Nicolau do Rio Pardo foi o primeiro aldeamento a se constituir enquanto tal, e ao que tudo indica, assim permaneceu ao longo de todo o século XIX. Percebe-se claramente que, em 1861, quando o comendador Patrício Câmara escreveu o relatório, São Nicolau do Rio Pardo ainda representava uma possibilidade de sobrevivência para alguns índios. Em 1862, mesmo depois de anunciada a sua extinção o desembargador Francisco de Assis Pereira Rocha informou ${ }^{39}$ :

Os índios da raça guarani que ainda permanecem na aldeia de São Nicolau em numero de 85 homens e 115 mulheres, com exceção de 12 que se empregam nos trabalhos da lavoura, os mais vivem em completa ociosidade, ou à espera de alguém que os procure para se empregarem como peões.

Ao longo de cem anos o modo de ser e se relacionar dos indígenas mudou, assim também como mudaram os significados da luta pela ocupação daquele espaço. Mas, mesmo depois de passar por tantas mudanças São Nicolau do Rio Pardo continuava a ser um espaço capaz de congregar índios vindos de outros lugares e possuidores de outras histórias. A recuperação dessas experiências transformadas ao longo do tempo pode reencontrar histórias perdidas nas fronteiras entre a realidade e a ficção presentes nos mais diversos discursos produzidos sobre essa parte do Brasil. Tal reencontro demonstra o que as ações dos indígenas puderam trazer para o futuro do aldeamento ${ }^{40}$ :

\footnotetext{
${ }^{39}$ AHPA. Relatório do Vice-Presidente da Província de São Pedro do Rio Grande do Sul, Francisco de Assis Pereira Rocha, na abertura da Assembléia Legislativa Provincial, 1862.

${ }^{40}$ AHPA. Relatório do Vice-Presidente da Província de São Pedro do Rio Grande do Sul, Eloy de Barros Pimentel, na abertura da Assembléia Legislativa Provincial, 1863.
} 
Sua população consta atualmente de 234 indivíduos da raça guarani, sendo homens 103 e mulheres 131; notando-se do mapa anterior, para mais de 18 homens e 16 mulheres. Não declarando o diretor geral de onde proveio esse aumento de população, nem em qual dos ramos de indústria se emprega, reporto-me ao que anteriormente se tem dito a respeito. Cabe aqui informar-vos que, tendo-se solicitado do Governo Imperial, pela secretaria do Estado dos Negócios da Agricultura, Comércio e Obras Públicas, a concessão das terras pertencentes a essa aldeia, a fim de estabelecer-se nela a colônia agrícola, de que trata a Lei Provincial no 493 de 11 de janeiro de 1862, foi declarado por aviso daquele Ministério de 29 de dezembro último, que por hora não podia ser atendido aquele pedido.

Quando a extinção do aldeamento era tida como certa e o futuro dos índios era dado como incerto nos discursos dos políticos, houve um aumento populacional. A solicitação para que as terras fossem concedidas para o estabelecimento de uma colônia agrícola não pode ser atendida. Percebe-se que alguns índios guaranis agiram no sentido de impedir ou retardar a extinção do aldeamento. Em 1863, Espiridião Eloy de Barros Pimentel mencionou pela última vez os índios de São Nicolau do Rio Pardo num relatório de presidente da Província. Outras fontes, no entanto, apontam indícios sobre sua presença mais tardia no aldeamento. Isso mostra que se posicionaram e foram capazes de atuar, mesmo que alguns dos discursos proferidos sobre eles vinculassem sua imagem à de índios do passado que estavam em vias de extinção. Eles fizeram parte daquele presente e suas imagens e atuações não passaram incólumes pelo tempo nos discursos dos políticos.

\section{3 - PRÁTICAS INDÍGENAS NOS DISCURSOS ECLESIÁSTICOS}

Em 1956, o Jornal Correio do Povo ${ }^{41}$ anunciava com 'grande júbilo' a criação do Instituto Estadual do Livro, bem como o plano de suas atividades, entre as quais a reedição de obras raras e esgotadas que 'tratam do Rio Grande do Sul'. Entre esses trabalhos, havia um inédito: o Ementário Eclesiástico do Rio Grande de São Pedro do Sul desde 1737, de

\footnotetext{
${ }^{41}$ O Correio do Povo é um jornal impresso brasileiro em formato tabloide com circulação no Estado do Rio Grande do Sul fundado a $1^{\circ}$ de outubro de 1895 por Caldas Júnior. Foi o jornal de mais longa publicação em Porto Alegre, circulando por 89 anos ininterruptamente, até 1984, reiniciando sua publicação em 1986.
} 
autoria do arcediago Vicente Zeferino Dias Lopes ${ }^{42}$. O Ementário é um manuscrito de 253 páginas e foi concluído em 1891. Segundo os dizeres desta matéria, publicada em 22 de setembro de 1956, pelo historiador militar Paranhos Antunes, “O Ementário em apreço é um verdadeiro cimélio pelas valiosas informações que contém”, pois o arcediago Lopes havia consultado ${ }^{43}$ :

(...) inúmeros documentos hoje desaparecidos, arquivos eclesiásticos e do governo, cartórios, Livros de Tombo das paróquias, além de ter mantido correspondências com quase todos os vigários das freguesias do Rio Grande (...). Nosso desejo seria anotar o Ementário, de vez que nele está a história das nossas primeiras vilas e cidades (...).

A matéria terminava com um apelo que, em 'ligeiras e despretensiosas linhas' lembravam aos diretores do Instituto Estadual do Livro, que incluíssem também em seus programas a edição de memórias inéditas sobre o nosso Rio Grande do Sul. O aldeamento de São Nicolau do Rio é mencionado em várias páginas do Ementário, e, certamente, essa presença constante no manuscrito denota sua importância para a história e memória sobre o Rio Grande do Sul. É inquietante pensar nos significados que o ineditismo das histórias dos índios guaranis de São Nicolau do Rio Pardo representa levando em conta o comentário de Paranhos Antunes. O Ementário traz informações inéditas sobre as relações de sociabilidade que os moradores da aldeia de São Nicolau estabeleceram com os moradores de Rio Pardo na parte intitulada 'Paróquias'"44:

\footnotetext{
${ }^{42}$ De acordo com Fábio Kühn, "O padre Vicente Zeferino Dias Lopes nasceu em Itaboraí, então província do Rio de Janeiro, no ano de 1818. Logo após ter sido ordenado, foi enviado como pároco de Viamão (18431847). Em seguida, tornou-se vigário em Rio Pardo, exercendo esta função entre 1847 e 1851. Com a criação do bispado do Rio Grande do Sul, passou a fazer parte do Cabido catedralício, tendo sido nomeado arcediago através de decreto imperial de 16.07 .1862 (cf. Rubert, 1998, p. 22, 26, 212). (...) O referido manuscrito - hoje disponível na forma de uma cópia datilografada - constitui um repositório importante de informações sobre a história eclesiástica do Rio Grande do Sul, não obstante algumas eventuais incorreções". KÜHN, Fábio. "'Um corpo, ainda que particular": irmandades leigas e Ordens Terceiras no Rio Grande do Sul colonial', in História Unisinos,. Vol. $14 \mathrm{~N}^{\mathrm{o}} 2$ - maio/agosto de 2010, p. 126. Disponível em: http://www.unisinos.br/publicacoes_cientificas/images/stories/pdfs_historia/vol14n2/art02_kuhn.pdf, site acessado em 17/02/2011.

${ }^{43}$ JORNAL CORREIO DO POVO, em Obras Inéditas Sobre o Rio Grande do Sul, de Paranhos Antunes, aos 22 de setembro de 1956.

${ }^{44}$ AHRS. DIAS LOPES, Vicente Zeferino. "Comentário Eclesiástico do Rio Grande de São Pedro do Sul desde 1737”. Cópia datilografada. p. 38-46.
} 
Este território então fronteiro, situado à margem esquerda do rio Jacuí na sua confluência com o Rio Pardo, (...). Por ordem do Capitão General Gomes Freire de Andrada foi designado em 1750 para estabelecimento de armazéns e depósitos de munições de guerra (...). Para os guardar na eminência, hoje conhecido pelo nome Alto da Fortaleza, levantou-se uma trincheira ou Forte chamado de Jesus Maria José. Em 1753, junto a este Forte edificou-se também uma Capelinha, coberta de palha, a qual se deu a mesma invocação (...). Em pouco tempo formou-se uma povoação composta de famílias brancas. A estas famílias agregou-se depois uma porção de índios extraviados de alguns dos sete povos jesuíticos; os quais se arrancharam em quatro pequenos aldeamentos; um chamado São Lourenço - nas imediações do atual cemitério do lugar denominado Potreiro de N. Senhora, junto a um regato que hoje conserva aquele nome; outro de Santo Ângelo, no alto onde está criada a casa de caridade, o qual por muitos anos deu nome a rua hoje chamada General Andrade Neves; outro de São Miguel, onde se fez a casa de pólvora; finalmente o de São Nicolau ${ }^{45}$, para onde o governador José Marcelino de Figueiredo fez recolher todos os índios, e os regularizar a 22 de outubro de 1769.

Antes de explorar esse trecho do Ementário, lembro ao leitor alguns aspectos do contexto de fundação do aldeamento de São Nicolau. Em 1750, os lusitanos buscaram incorporar territórios espanhóis às suas possessões através do tratado de Madri. Uma série de conflitos foi desencadeada, envolvendo negociações nas quais os indígenas guaranis das missões orientais do Uruguai estiveram envolvidos de maneira crucial. Tais indígenas eram disputados pelas Coroas, assim como o território que ocupavam. Foi acordado entre Portugal e Espanha que a colônia de Sacramento faria parte das possessões espanholas em troca dos sete povos das missões orientais do Uruguai, que passariam ao domínio dos portugueses. Os indígenas não foram consultados sobre o tratado, se negaram a fazer parte dele e a transmigrarem. Nesse contexto, que foi um dos episódios mais polêmicos para a história da América meridional, os indígenas travaram um conflito contra as Coroas ibéricas, que ficou conhecido como Guerra Guaranítica (1754-1756). A ação dos indígenas 46.

Foi de dupla ordem: escrita e armada. Nesse período de conflito redigiram os Guarani inúmeros documentos, destinados a seus parentes, padres ou autoridades, procurando defender seus interesses.

\footnotetext{
${ }^{45}$ Os grifos são do autor.

46 NEUMANN, Eduardo. "Mientras volaban correos por los pueblos": autogoverno e práticas letradas nas missões Guarani - século XVII. Horizontes Antropológicos, Porto Alegre, v. 10, n. 22, Dec. 2004. p. 95.
} 
Sobre o trecho escrito pelo arcediago, interessa salientar que, na historiografia sobre os povos guarani-missioneiros não é mencionada a existência dos demais aldeamentos fundados separadamente do aldeamento de São Nicolau em Rio Pardo. Até então, pensavase que os índios que negociaram com Gomes Freire de Andrade e aceitaram um acordo para virem para o lado português tivessem sido arranchados em conjunto. Os demais índios teriam se dispersado e formado aldeias não reconhecidas e não regularizadas pelo Estado. Entretanto, de acordo com o manuscrito do arcediago Lopes, os índios fundaram quatro aldeamentos em Rio Pardo, que teriam sido reconhecidos e mantidos até 1769, quando o governador José Marcelino tentou recolhe-los no aldeamento de São Nicolau do Rio Pardo.

Esse é um fato muito importante, sobretudo quando se sabe que, das missões orientais do rio Uruguai, as lideranças e os integrantes que mais estiveram envolvidos na Guerra Guaranítica foram São Nicolau, São Miguel, Santo Ângelo e São Lourenço. De acordo com Eduardo Neumann ${ }^{47}$ :

Depois de um breve e inicial período de convencimento dos índios, os jesuítas esbarraram exatamente na oposição empedernida de São Nicolau, a mais intransigente à ordem de mudança. $O$ recurso acionado foi a escrita, que serviu de meio para insuflar os demais, pois os índios de São Nicolau (...) lograram, através da ação de alguns principais, sublevar os índios de São Miguel. Um dos principais artífices da operação de resistência nicolaísta foi Cristoval Paica, (...). Devido à ação desse índio, a resistência alastrou-se às demais reduções, visto que três delas, no caso, São Lourenço, São Luís e São Borja, já haviam dado início à mudança.

É instigante pensar nas condições em que esses indígenas teriam firmado um acordo com Gomes Freire de Andrade e conseguido restabelecer e transpor para território lusitano nomes de lugares onde haviam tido experiências com os espanhóis. O que teriam pensado as lideranças e os índios guaranis ao aceitarem estabelecer uma aliança com seus inimigos históricos - os portugueses - contra seus antigos aliados - os espanhóis? Será que uma exigência referente aos nomes dos lugares onde iriam se estabelecer fez parte da negociação? Será que os índios tentaram manter a organização dos seus espaços tal como faziam no lado espanhol, preservando inclusive o nome dos povos? Difícil saber. O certo é

\footnotetext{
${ }^{47}$ NEUMANN, Eduardo. Op. Cit. 2004. p. 102-103.
} 
que tal negociação contribuiu sobremaneira para construir novas fronteiras territoriais, políticas e étnicas no sul da América meridional. Diante desse contexto de redefinição de fronteiras entre aliados e inimigos históricos, os índios lutaram para reivindicar seu território em sentido contrário às determinações metropolitanas. Durante a Guerra Guaranítica (1754-1756) os índios tentaram exercer um autogoverno e 'pegaram em armas e em papéis', lutaram com armamentos e com discursos que pudessem contribuir para seu

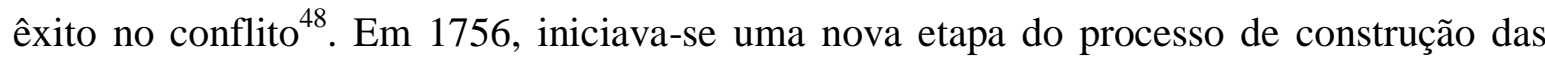
complexidades fronteiriças, sem que as negociações conflituosas entre índios, missionários, espanhóis e portugueses tivessem terminado. Tal processo se desencadeou ao longo do século XIX, durante o qual o aldeamento de São Nicolau do Rio Pardo parece ter sido um espaço fundamental para a vivência e para a sobrevivência de índios guaranis. A missão de São Nicolau foi uma das mais atuantes e resistentes em ceder o território que julgava ser seu, e São Nicolau do Rio Pardo também foi o aldeamento que mais esteve envolvido em guerras e conflitos gerados em torno das lutas por controle territorial. Foi também o único que conseguiu exercer certo domínio sobre suas terras junto às esferas políticas da época colonial e provincial, assegurando que aquele espaço fosse eminentemente indígena ao longo de, praticamente, todo o Oitocentos. Prova disso, é o que escreve o arcediago Lopes sobre os índios e as relações sociais que estabeleceram através de um espaço constantemente acionado por eles, a igreja de São Nicolau do Rio Pardo ${ }^{49}$ :

A 12 de outubro de 1812 os índios obtiveram licença do Visitador Padre Agostinho José Mendes dos Reis para que o padre José Alexandre de Borba, que era capelão por eles, lhes administrasse os sacramentos do batismo, penitência, extrema unção, e também o matrimônio depois dos cônjuges se habilitarem perante o vigário da Vara de Rio Pardo. Com a morte do capelão terminou a graça, $e$ os índios ficaram sujeitos ao vigário de Rio Pardo. Este lugar está hoje despovoado, e nele vivem ainda alguns descendentes dos primitivos habitantes, e decaiu principalmente depois que a Lei provincial $n^{o} 1114$ de 21 de novembro de 1860 extinguiu o aldeamento. Existe a capela sempre reformada, e velhos ornamentos; e no único altar uma bela imagem de São Nicolau, uma de N. S. da Conceição doada por Antônio José de Moura, e outra do Espírito Santo, havendo várias na Sacristia feitas pelos índios, mas imperfeitíssimas.

\footnotetext{
${ }^{48}$ Sobre a prática da escrita entre os índios durante a guerra Guaranítica ver NEUMANN, Eduardo Santos. Op. Cit. 2005.

${ }^{49}$ EMENTÁRIO. Op. Cit. 1891. p. 138.
} 
Embora o arcediago tenha, por algum motivo, suprimido cerca de 50 anos da história de São Nicolau, ao passar imediatamente do ano de 1812 para o ano de 1860, como se nada tivesse ocorrido nesse intervalo, e como se a extinção do aldeamento decorresse apenas da perda da administração dos sacramentos; por outro lado, recupera outros anos ao afirmar que, por volta de 1891 - ano de conclusão do Ementário - ainda viviam 'alguns descendentes' dos 'primitivos' moradores. Isso significa que a extinção do aldeamento não levou, necessariamente, ao seu esvaziamento. Significa também que mesmo as histórias e obras mais escondidas e ocultadas, por serem consideradas 'imperfeitas' e 'inferiores', e, portanto, capazes de macular a presença de imagens consideradas 'belas' e 'perfeitas', podem ter sua visibilidade garantida graças, justamente, à sua imperfeição.

Segundo o método de Giovanni Morelli, criado por volta de 1875 para devolver a autoria de obras de arte aos seus verdadeiros autores, é necessário não se basear em características comuns, como usualmente é feito, mas em características menos vistosas e, portanto menos imitáveis. Para Morelli, os pormenores mais passíveis de negligência eram reveladores porque era algo que fugia do controle do artista. Carlo Ginzburg ressaltou o método morelliano de encontrar em detalhes, muitas vezes implícitos nas entrelinhas, indícios tão valiosos quanto o que parece ser óbvio: "Morelli propunha-se buscar no interior de um sistema de signos culturalmente condicionados, como o pictórico, os signos que tinham a involuntariedade dos sintomas (e da maior parte dos indícios, também involuntários)" 50 .

As obras de arte esculpidas pelos indígenas de São Nicolau do Rio Pardo para colocarem na capela construída e constantemente reformada por eles foram postas na sacristia a revelia de seus criadores. Não é descabido dizer que, assim como as obras de arte, suas histórias não puderam ser vistas e tiveram seu protagonismo relegado ao plano da marginalidade. Porém, como as obras de arte cujos autores Morelli encontrou para devolver-lhes a autoria, assim também é possível, pelo mesmo método, recuperar obras de arte e patrimônios históricos que não se restringem às ruínas missioneiras, mas à riqueza das experiências vividas durante os contextos e os eventos que fizeram com que índios guaranis se deparassem com situações limite, que colocavam à prova a sua sobrevivência

${ }^{50}$ GINZBURG, Carlo. Mitos, Emblemas, Sinais. São Paulo, Cia das Letras, 1989. p. 143-180. 
física e étnica. A indigência e a miséria na aldeia são constantemente relatadas em outras fontes, como se verá a seguir.

Ademais, poderia se pensar que a obra do arcediago Lopes também é bastante 'imperfeita', visto que ele não demonstra ter melhor interesse e conhecimento sobre os índios do que aqueles a quem critica no Ementário. Trata-se da involuntariedade dos sintomas e dos signos do chamado paradigma indiciário ${ }^{51}$. A obra de arte do arcediago Lopes, o Ementário, carrega os mesmos indícios e sinais das imagens que ele julgou imperfeitas. Tais imperfeições dão visibilidade às ações dos índios de São Nicolau do Rio Pardo. Segundo o arcediago, em outra passagem do manuscrito, em 1753, Gomes Freire "foi encarregado de acomodar índios Tapuias extraviados das missões" ${ }^{52}$. Os Tapuias ${ }^{53}$ são, segundo os discursos historiográficos e políticos do século XIX, índios selvagens que não passaram por experiências prévias de catequização, ao contrário dos índios missioneiros, a quem o arcediago se refere. De acordo com os referidos discursos, portanto, os guaranis seriam enquadrados dentro da categoria Tupis. Assim, mesmo tendo revelado repetidas vezes um grande desconhecimento sobre os índios a quem lastimava não ter conquistado, convertido e civilizado, a imperfeição dos seus escritos revela com certa perfeição a complexidade daquele contexto. Afinal, está na imperfeição do detalhe no qual o arcediago revelou que não haveria mais índios em São Nicolau do Rio Pardo, mas somente seus descendentes, pistas que conduzem ao indício da presença indígena no aldeamento no ano de 1891, cerca de 30 anos após sua extinção. Assim também, é possível perceber que os indígenas continuaram a ornamentar a igreja de São Nicolau, talvez numa tentativa de estabelecer relações sociais que lhes garantissem a permanência naquele território, ainda que o aldeamento tivesse sido extinto na década de 1860. Mesmo que suas imagens 'imperfeitas' estivessem na sacristia e não no altar da igreja construída por eles, o lugar ainda era ocupado por eles.

\footnotetext{
${ }^{51}$ IDEM.

${ }^{52}$ EMENTÁRIO. Op. Cit. 1891. Pg. 216.

${ }^{53}$ Para maiores detalhes sobre as concepções da época sobre as categorias inventadas de Tupis e Tapuias ver MONTEIRO, John Manuel. Op. Cit. 2001, com destaque para o capítulo 9, Tupis, Tapuias e a História de São Paulo: Revisitando a Velha Questão Guainá, p. 180-193.
} 
Os índios de São Nicolau do Rio Pardo reconstruíram várias vezes sua capela e em diferentes locais do aldeamento. Ela simbolizava a religiosidade cristã desses indígenas. Eles possuíam privilégios, como o monopólio do plantio, colheita e comercialização da erva-mate. Quando esse privilégio foi ameaçado em 1823, houve alegações por parte dos índios que tal concessão garantia o seu sustento e a manutenção de sua capela. Com essa atitude demonstraram que a capela era importante para eles. É importante salientar que, apesar da política de assimilação do Estado brasileiro, os indígenas possuíam alguns direitos territoriais pautados, sobretudo, em suas identidades étnicas e culturais. Por isso, parecia ser fundamental manter vínculos e alianças com o Estado, com quem estavam em constante situação de conflito e negociação (ou seja, fazer parte dele), e ao mesmo tempo, garantir que o sentido de sua identidade não fosse tomado como algo passível de ser assimilado em meio às políticas indigenistas, das quais a prática da catequese fazia parte. Por isso, é possível perceber o cuidado dos índios em manter a vivacidade da religiosidade cristã através do espaço da igreja no aldeamento. Podemos dizer que a religiosidade e a própria igreja foram transformadas pelos índios sempre que acharam necessário. Em alguns momentos eles recuperam conhecimentos aprendidos no passado, e que faziam parte do seu presente, como os atos de esculpir santos católicos. 


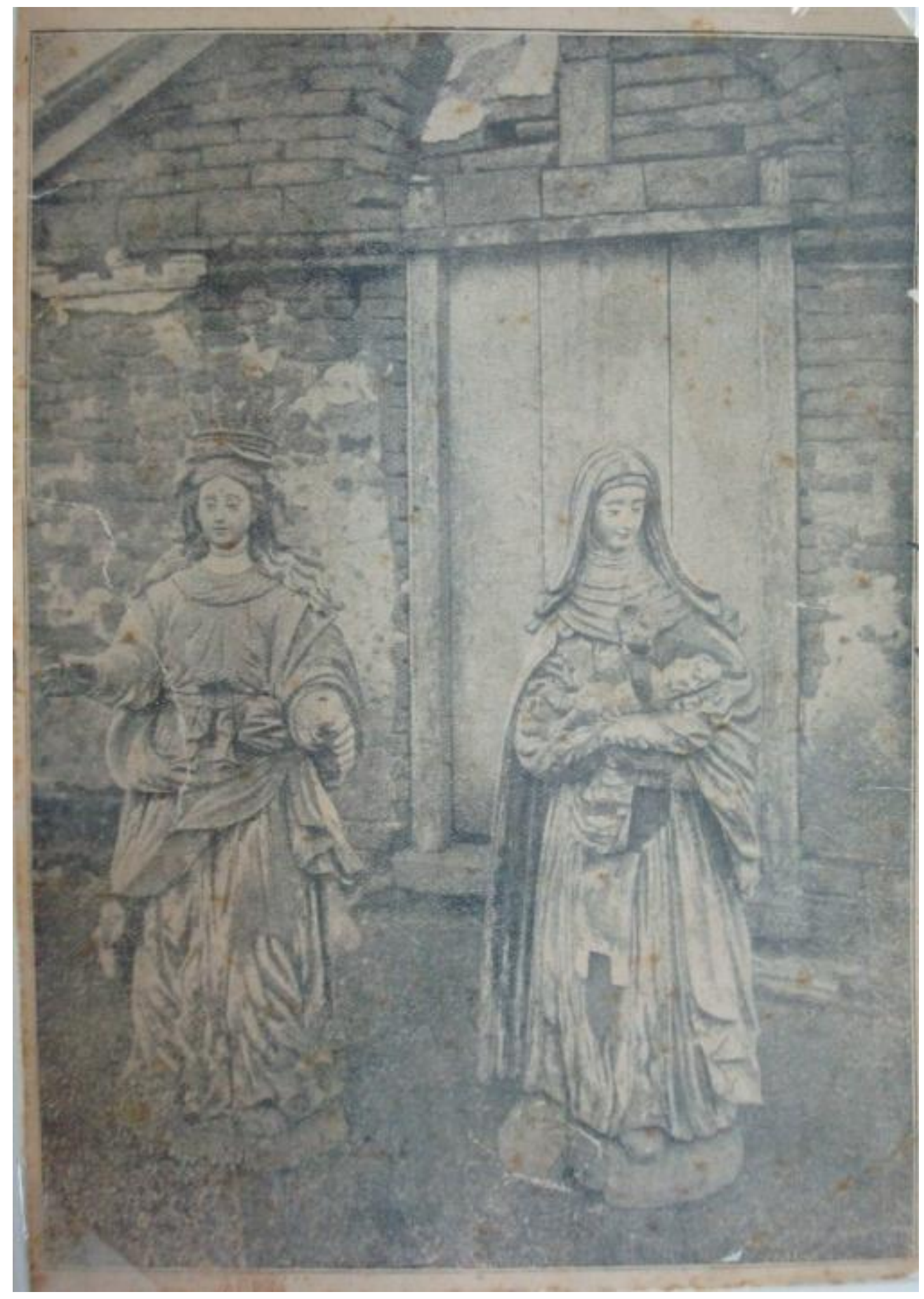

IMAGEM 10: Esculturas Missioneiras

Fonte: AHRS, Fundo Iconografia, Pasta 50, Missões - 042. 
O arcediago escolheu o tópico Catequese para encerrar o Ementário e relatou graves denúncias em tons de desabafo. Suas críticas tornam-se ainda mais contundentes quando se percebe que foram feitas baseadas em consultas a documentações eclesiásticas e oficiais. Ele escreveu sobre a chegada de missionários franciscanos, capuchinhos, e jesuítas, sendo que dentre esses últimos se encontravam espanhóis, italianos e alemães. Também narrou, entre 1737 e 1863, as atividades desempenhadas pelos missionários e as medidas provinciais tomadas para que elas pudessem ser realizadas ou não. Segundo suas pesquisas e interpretações ${ }^{54}$ :

Nesta Província nem antes nem depois de ser elevada a Bispado se tem cuidado da catequese dos indígenas com grande interesse, e por isso as Leis evangélicas não tem iluminado os filhos das selvas, que continuaram a servir sem instrução nem educação, habitando as florestas, $e$ na maior ignorância, quando se podiam tornar úteis ao Estado se os civilizassem.

É interessante observar que, segundo as colocações do arcediago, ao contrário dos padres, os indígenas continuaram a servir ao Estado, mesmo habitando as selvas e não tendo a educação e a instrução consideradas necessárias à sua civilização, e, por conseguinte, à habilitação para prestar serviços úteis à nação. Entretanto, os missionários, mesmo sendo possuidores de todo o instrumental necessário para civilizar os 'selvagens' o conhecimento e a religião - optaram por morar na maioria dos casos longe da selva, e longe dos 'selvagens', preferindo ensinar àqueles que eram considerados 'civilizados" ${ }^{, 55}$ :

Todos estes sacerdotes enviados a pregar o Evangelho, aos selvagens, digno objeto de sua missão, contentaram-se a pregá-lo aos povos já civilizados. Desde então nenhum Sacerdote mais foi encarregado de pregar aos indígenas até 1842, em que chegaram em Porto Alegre os padres espanhóis da Companhia da Jesus, João Cori, Manoel Mattos e João Solanellas, os quais se restringiram a pregar na capital, em algumas Freguesias vizinhas, à convite dos povos.

\footnotetext{
${ }_{55}^{54}$ EMENTÁRIO. Op. Cit. 1891. p. 218-253.

${ }^{55}$ IDEM.
} 
Com essa ação, os missionários, mesmo sendo 'civilizados', não parecem ter sido tão úteis ao Estado quanto foram os índios, quer tenham sido considerados 'selvagens' ou não. Além disso, nem todos os indígenas eram privados do acesso à instrução. Existiu em São Nicolau do Rio Pardo uma escola para o ensino exclusivo de meninos guaranis, onde os mesmos aprendiam música, aritmética e língua portuguesa. Assim, a utilidade dos indígenas para a Província de São Pedro não parece ter dependido exclusivamente de sua 'civilização', pois mesmo habitando as matas e não tendo instrução, alguns deles prestaram diversos serviços ao Estado. Em contrapartida, a maioria dos padres missionários, mesmo tendo vindo para tal e tendo a instrução necessária para desempenhar tal tarefa, optou por não fazê-lo. Do mesmo modo, nem todos os indígenas 'civilizados' prestaram serviços ao Estado ou à Província, mas também para particulares. De qualquer forma, tanto os missionários, quanto os índios, pareciam estar cuidando de seus interesses, e de maneiras muito variadas. Ao passo que houve atitudes como as do padre Antônio de Almeida Leite Penteado, que "ofereceu-se para levar aos toldos dos índios errantes pelas imediações de Passo Fundo os confortos da religião" e "cheio de fé percorreu alguns lugares onde havia selvagens, doutrinou-se, e (...) administrou-lhes os Sacramentos do Batismo e do Matrimônio", houve também religiosos franciscanos que se limitaram a fundar "um hospício e nunca de lá saíram",56. O padre Antônio Penteado se afastou das atividades quando adoeceu. Não se sabe se ele esteve mesmo cheio de boas intenções com os índios para os quais se ofereceu a ir levar a religião católica, mas suas atitudes foram tidas como apropriadas e condizentes com a missão dos padres na Província, segundo a opinião do arcediago Lopes.

Entre as práticas que parecem ter sido comuns estão os trabalhos e as atividades religiosas vilipendiadas pelos missionários. Entre as particularidades está o modo como cada religioso optou por deixar de lado as tarefas para as quais foram designados. Houve aqueles que fundaram hospícios e se internaram neles para não mais saírem, aqueles que excederam outras "faculdades" não condizentes aos impedimentos do matrimônio,

\footnotetext{
${ }^{56}$ IDEM.
} 
quebrando o voto do celibato. Outros juntaram pecúlio e compraram imóveis, mesmo sendo proibidos de efetuar transações comerciais, como o capuchinho Fr. Caetano de Troina ${ }^{57}$ :

Tendo comprado uma chácara no Arraial do Menino Deus próximo a Capela foi nela habitar, e por portaria de S. E. Rma., de 24 de julho de 1863, foi à Paróquia de Jaguarão substituir o distinto pároco Joaquim Rodrigues Lopes, que se oferecera a ir prestar serviços no Paraguai. Em poucos meses tornou ao Menino Deus, por terem os credores da pessoa em cujo nome tinha sido comprada a dita chácara tomado-a por dívida, visto que o proprietário como frade não podia fazer.

Houve casos em que os religiosos encarregados pela presidência da Província de atividades como a visita aos aldeamentos, não a cumpriam por inteiro. É importante ressaltar que na maioria destes casos, todas as despesas das atividades missionárias, realizadas ou não, eram cobertas pelos cofres da Província. Além disso, ao longo do século XIX, e sobretudo ao final dele, vários aldeamentos extintos foram espoliados por padres e autoridades políticas. Em 1885, por exemplo, a Câmara de vereadores de Porto Alegre recebeu uma correspondência do governador da Província do Rio de Janeiro, Cesário Alvim, pedindo auxílio para reunir objetos indígenas para serem remetidos ao Museu Nacional ${ }^{58}$.

Por outro lado, nem sempre nobres intenções como parecem ter sido as do padre Antônio Penteado foram bem recebidas, na opinião do arcediago. Se a má conduta da maioria dos missionários era questionada pelas autoridades políticas e repudiada por alguns religiosos, como foram recebidas as atitudes daqueles que queriam desenvolver as atividades religiosas com o afinco que julgavam inerentes à missão? O arcediago narrou outro caso interessante que nos mostra o outro lado da moeda. Em 1846, apareceu na paróquia de Nossa Senhora do Rosário do Rio Pardo, "um italiano trajando hábito preto cingido por um cordão branco, e aparentando espírito religioso e vida austera, era

\footnotetext{
${ }^{57}$ IDEM.

${ }^{58}$ AHPA - Correspondência passiva da Câmara de Vereadores de Porto Alegre. Livro No 40.30 de abril de 1885.
} 
conhecido pelo nome de 'Monge", 59 . O 'italiano'escolheu a Matriz de Nossa Senhora do Rosário para fazer uma pregação. A permissão veio com o consentimento do vigário, do provedor da irmandade e de pessoas ilustres na cidade. Porém, a experiência da pregação, ou a prática do discurso, não foi bem recebida pelos fiéis da paróquia quando o 'Monge' ${ }^{60}$ :

Subindo ao púlpito profanou o lugar santo, e usando de uma linguagem desaforada desacatou as famílias presentes, dirigindo-lhes palavras grosseiras. Descendo do púlpito, retirou-se, e estando distante da Igreja recebeu umas bengaladas em remuneração de tanto arrojo. Não mais voltou e foi habitar o cume do serro de Botucaraí, [n] uma ermida dedicada a Santo Antão, a qual era muito freqüentada pelas pessoas ignorantes, prontas em tudo crer, menos nas máximas e preceitos do Evangelho, e por muitos doentes vindos de vários lugares, dos quais alguns morreram, e outros voltaram do mesmo modo.

As atitudes do religioso italiano durante aquela missa foram responsáveis por severas punições que ele recebeu mais tarde. $\mathrm{O}$ 'Monge' foi agredido devido às palavras ditas por ele durante a homilia - um discurso acionado e usado para a pregação da prática cristã - que realizou na Igreja de Nossa Senhora do Rosário do Rio Pardo. Todavia, ele não desistiu daquilo que considerava ser a sua missão e foi morar entre os 'ignorantes' e doentes. Segundo o arcediago Lopes, o Botucaraí, lugar onde o 'Monge' se refugiou, era ocupado por índios não-aldeados. O 'italiano', tendo recebido algumas bengaladas, argumentou que se comunicava com os anjos, que o haviam aconselhado a ir àquele lugar. Ele parece ter feito amigos e inimigos fiéis, visto que foi ouvido por aqueles que estiveram

${ }^{59}$ EMENTARIO. Op. Cit. 1891. p. 44. Aqui se faz necessária uma breve explicação sobre a paróquia de Nossa Senhora do Rosário. Até 1797, a Matriz de Nossa Senhora do Rosário era denominada Matriz de Santo Ângelo. Provavelmente este último nome da paróquia esteja relacionado com a vinda dos guaranis para a região de Rio Pardo, especialmente aqueles que fundaram o aldeamento de Santo Ângelo. Conforme o arcediago, na antiga capela de Santo Ângelo já existia uma pequena imagem de Nossa Senhora do Rosário. Em 1797, foi trazida da Bahia e colocada no alto do trono outra 'grandiosa imagem de N. S. do Rosário', à custa da Irmandade do Santíssimo Sacramento do Rio Pardo. Neste ano, os oragos e os nomes das paróquias foram trocados. Nossa Senhora do Rosário se tornou a padroeira da matriz no lugar de Santo Ângelo. Do mesmo modo que a imagens esculpidas pelos índios foram postas de lado, a imagem de Nossa Senhora do Rosário foi, em 1884, colocada em outro lugar da sacristia pelo próprio arcediago Lopes 'por não haver lugar em nenhum dos altares'. Tomando-se como base que Nossa Senhora do Rosário é um orago 'tradicionalmente' invocado pelas irmandades formadas por negros e escravos, pode ser que a conjuntura daquele contexto e o evento da abolição da escravatura, que viria a acontecer em 1888, mas já dava sinais de seus antecedentes, tenha corroborado para a troca dos santos nos altares daquela igreja.

${ }^{60}$ IDEM. p. 45. 
'prontos em tudo crer' e acolhido por pessoas consideradas ignorantes, por doentes e indígenas no alto do Botucaraí. Mesmo assim, em 1848, foi mandado retirar pelo presidente da Província "por causa das imoralidades que resultaram da grande aglomeração de povo que [lá] ia a crescer, foi finalmente justiçado na Itália" ${ }^{61}$. Se o fim dos poucos religiosos que vieram para a Província de São Pedro, e, de fato se interessaram pela missão junto aos índios, era adoecer em função dos seus trabalhos - como no caso do padre Antônio Penteado - ou ser privado de realizar suas atividades para ir a julgamento por tentar cumpri-las - como no caso do 'Monge' - não é de se admirar que os demais missionários não tenham querido ir aos sertões e sim optado por permanecer em hospícios, ou próximos aos diversos tipos de gabinetes (políticos e religiosos) dos centros urbanos.

Segundo o arcediago, aquele seria um esboço do que tinha havido sobre aldeamentos e catequese na Província desde o ano de 1737 até o ano de 1891, quando o Ementário foi concluído. Ele enfatizou que seus escritos foram extraídos de Relatórios de Presidente de Província e de outros documentos de $\operatorname{arquivo}^{62}$ :

Neste esboço extraído dos Relatórios dos Presidentes da Província, e de documentos que se conservam nos arquivos, está tudo quanto tem havido a respeito de Aldeamentos e Catequese. Este estado lastimoso durará sem dúvida; e enquanto não houver providências, os filhos das selvas continuarão a viver nas trevas sem instrução, sem educação e sem civilização.

O arcediago Lopes se limitou a narrar os fatos extraídos das informações presentes na documentação, expressando-se nas entrelinhas. Entretanto, manifestou sua opinião ao final do texto concluindo que lastimava aquele estado de coisas. Lamentava que o comentário histórico feito por ele desde 1737 sobre as atividades eclesiásticas do Rio Grande de São Pedro terminasse daquela maneira, sem alcançar seus objetivos. Escolheu encerrar os 154 anos da 'história eclesiástica' na Província do Rio Grande com o tópico Catequese. O final descrito por ele não foi feliz e revelou algo mais do que um simples desapontamento, mostrou que sua percepção dos fatos esteve ligada aos sentimentos de

\footnotetext{
${ }^{61}$ IDEM.

${ }^{62}$ IDEM. p. 218-253.
} 
frustração, impotência e culpa. Mas, se esse discurso sobre a história do fracasso da catequese na Província é bastante enviesado, as escolhas feitas pelos padres missionários contribuíram para a sua conformação. Quanto ao final, que pode não ter sido assim tão infeliz para outros, não teria se configurado daquela forma se não fosse a atuação dos índios, ainda que essa atuação fosse vista pela maioria dos padres e políticos como um simples ato de não-colaboração, decorrente de sua incapacidade de mudar.

Diante desse quadro, vale ressaltar que a história dos índios guaranis de São Nicolau do Rio Pardo não terminou ao início do século XIX, com 'a conquista dos sete povos das missões'; e nem mesmo na década de 1860, quando o aldeamento de São Nicolau foi extinto. As redes sociais que esses indígenas construíram parecem ser bem mais amplas do que se pensou, e como se pode notar, suas relações sociais são igualmente mais complexas e geraram atos de solidariedade e força, como os do 'Monge', das pessoas que o acolheram, das que o agrediram e extraditaram. Esses atos contam suas histórias. 


\section{CAPÍTULO 2 - A ALDEIA DE SÃO NICOLAU DO RIO PARDO}

\section{1 - INTRODUÇÃO}

No século XVIII, os contatos entre portugueses, espanhóis, jesuítas e guaranis se intensificaram na chamada região platina. Mas antes da chegada dos colonizadores e missionários europeus, esses índios já eram agentes da sua história, e assim continuaram sendo após iniciado o longo processo de conquista territorial das Américas. Durante todo esse tempo de encontros e desencontros entre mundos e culturas diferentes, a construção de novos mundos também se deu a partir das relações entre colonizadores e os indígenas com os quais entravam em contato ${ }^{63}$.

No extremo sul da América portuguesa, atual estado do Rio Grande do Sul, os lusitanos buscaram incorporar territórios espanhóis às suas possessões através do Tratado de Madri (1750). Uma série de conflitos foi desencadeada, envolvendo outra série de negociações nas quais os indígenas guaranis das missões orientais do rio Uruguai estiveram envolvidos de maneira crucial. Eles foram alvo de disputa entre as Coroas, que sabiam da importância de manter alianças com os mesmos e buscavam novos súditos que lhes garantissem a posse do território. Os índios guaranis representavam um contingente populacional capaz de ocupar a terra e, simultaneamente, defendê-la. Ao mesmo tempo, garantir-lhes o sustento através do seu próprio trabalho nos aldeamentos se apresentava como um problema e um grande desafio para a Coroa portuguesa. Após a expulsão dos jesuítas em 1759, a 'administração' dos índios passou a ser secular e as mudanças na vida dos aldeados foram muitas. Com isso, uma das preocupações centrais do governo português, principalmente durante a década de 1760, era constituir aldeias em locais estratégicos, tanto do ponto de vista geopolítico, quanto econômico. Em 1757, em virtude do não-cumprimento do Tratado de Madri, cerca de 700 famílias de índios missioneiros foram trazidas por Gomes Freire de Andrada e arranchadas nos arredores de Rio Pardo, na aldeia denominada São Nicolau do Rio Pardo. O território ocupado pela aldeia também se

\footnotetext{
${ }^{63}$ RUSSELL-WOOD, A. J.R. Um mundo em movimento: os portugueses na África, Ásia e América (1415-
} 1808). Lisboa: Difel, 1998. 
encontrava em situação de litígio fronteiriço. Gomes Freire deu algumas instruções para o estabelecimento dos indígenas que estavam em Rio Pardo e para aqueles que continuavam a chegar. Tais instruções pareciam estar de acordo com as diretrizes assimilacionistas oriundas do Diretório dos Índios ${ }^{64}$. A política de assimilação dos indígenas previa a eliminação de quaisquer diferenças entre 'brancos' e 'índios'. De acordo com ela, a integração dos indígenas só seria possível se eles fossem civilizados de acordo com os hábitos, costumes religiosos e culturais dos portugueses.

Dos cinco aldeamentos guarani-missioneiros fundados em território luso por ocasião de vários fluxos migratórios, São Nicolau do Rio Pardo parecia ser o ponto de partida e chegada para os demais. Dele foram transferidas as populações indígenas que formaram os aldeamentos de Santo Antônio da Patrulha e de Nossa Senhora dos Anjos; assim como também recebeu os indígenas dos aldeamentos que se mantiveram por pouco tempo, como o de Nossa Senhora da Conceição do Estreito e provavelmente São Nicolau do Rio Pardo do Jacuí. São Nicolau do Rio Pardo foi o primeiro aldeamento de origem guaranimissioneira do Continente constituído nos moldes que remetem aos da política assimilacionista do marquês de Pombal e o último a se desmantelar.

\footnotetext{
${ }^{64}$ Assinado em 1758, o Diretório dos Índios era um conjunto de normas e instruções, cujo principal objetivo era inserir o indígena às sociedades que se formavam na América portuguesa, e a sua principal característica era o assimilacionismo. O Diretório regulava basicamente cinco aspectos a serem administrados no aldeamento. Exponho de maneira sucinta a ordem de prioridade destes aspectos, conforme classificação de Rita Heloísa de Almeida: a questão da civilização dos índios, assuntos relativos à economia, à tributação, ao comércio e à distribuição da força de trabalho indígena. No Diretório, 16 artigos são referentes à civilização; 8 à economia; 8 à fiscalização e tributação; 23 ao comércio; 14 à distribuição da força de trabalho do índio. Um número maior de artigos se destina à causa comercial (23), mesmo sem levarmos em consideração que igualmente mercantis são aqueles outros 30 artigos que tratam da economia, da fiscalização e tributação, e por fim da distribuição da mão-de-obra indígena. Apesar da divisão teórica, todos estes aspectos estão imbricados e se inserem num âmbito maior e mais complexo, o das relações e transformações sócio-culturais. ALMEIDA, Rita Heloísa de. O Diretório dos Índios. Um projeto de civilização no Brasil do século XVIII. Brasília: Editora UnB, 1997, p. 63-93.
} 


\section{PRIMEIRAS POVOAÇÕES DO RIO GRANDE DO SUL}

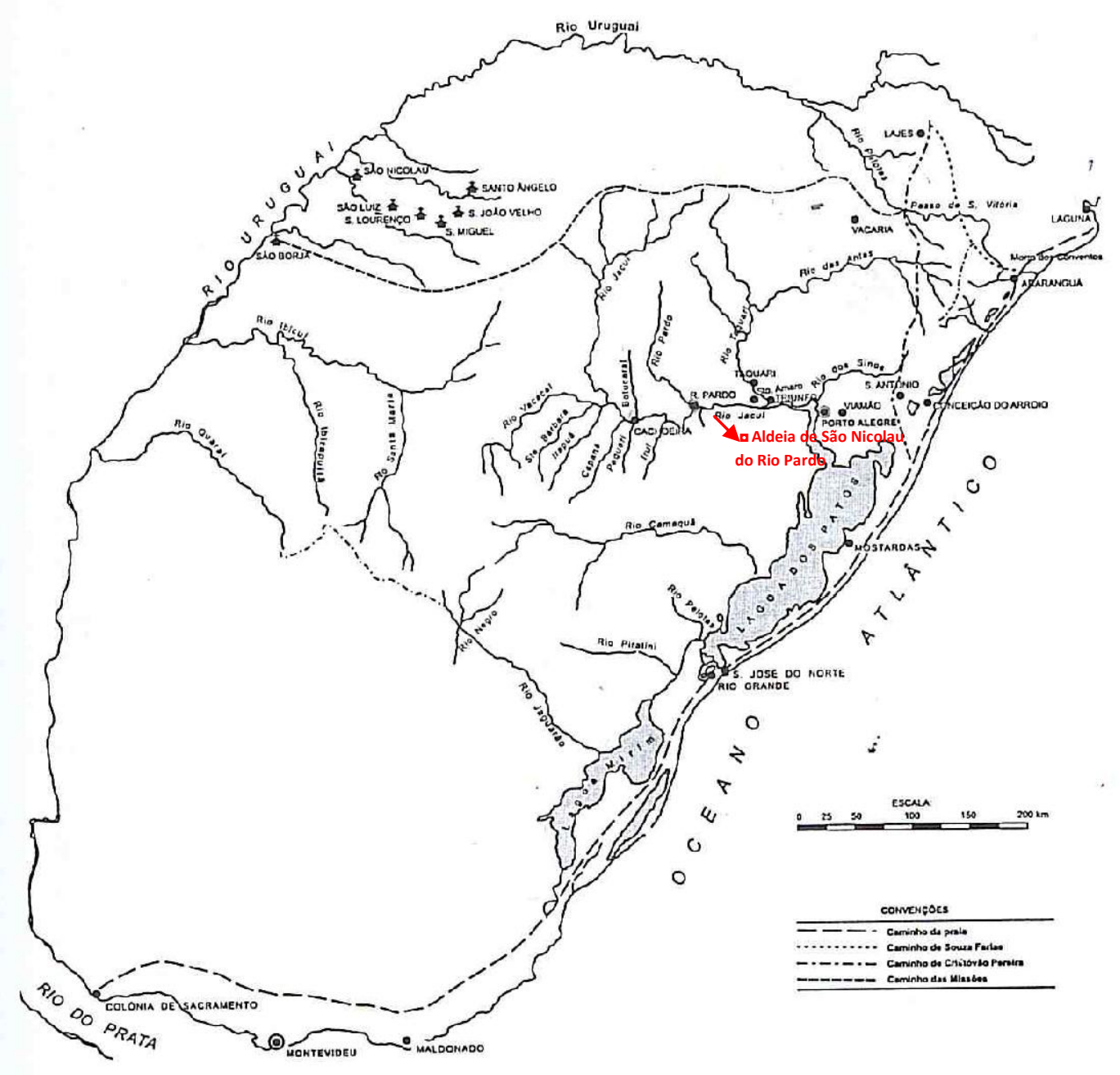

IMAGEM 2 - Mapa das Primeiras Povoações do Rio Grande do Sul

Fonte: Vellinho, Moysés. Capitania d'el Rey: aspectos polêmicos da formação rio-grandense. Porto Alegre: Globo, 1970. APUD: KÜHN, Fábio. Breve História do Rio Grande do Sul. Porto Alegre: Leitura XXI, 2004 [2002], p. 51. Mapa modificado. 
Enquanto os demais aldeamentos guarani-missioneiros do Continente do Rio Grande se extinguiram ou se transformaram em vilas e freguesias, São Nicolau do Rio Pardo permaneceu como uma aldeia indígena até o terceiro quartel do século XIX. Logo, foi o único que vivenciou variadas mudanças de contexto sócio-político e experiências de contato. Ele foi fundado num território que pertencia à Coroa portuguesa e extinto no território do Império do Brasil, na Província de São Pedro.

Quais motivos teriam levado São Nicolau do Rio Pardo a permanecer enquanto um aldeamento e quais razões possibilitaram sua sobrevivência durante este considerável período? As razões de sua longevidade não podem ser entendidas sem levar em conta as ações dos guaranis que o compuseram ao longo do tempo. Não se tratou somente dos interesses de autoridades coloniais e provinciais. A sua formação e extinção também esteve ligada aos interesses dos próprios índios, cujas atuações serão abordadas ao longo deste capítulo, a começar pelo período de formação do aldeamento.

\section{2 - LUGAR DE CASTIGO OU RECOMPENSA PARA DESERTORES E 'CHINAS'}

Durante a segunda metade do século XVIII, São Nicolau do Rio Pardo encontrava-se entre limites fronteiriços dos Impérios ibéricos e essa posição geográfica e política peculiar fez com que os indígenas tivessem suas chances de mobilidade espacial aumentadas. O tema sobre as fugas para e dos arredores de Rio Pardo está presente em vários documentos e já foi abordado em alguns trabalhos ${ }^{65}$. A documentação utilizada a seguir é inédita e traz informações importantes sobre o contexto de formação de São Nicolau do Rio Pardo ${ }^{66}$. Em 1759, o governador geral da Província do Rio da Prata e da cidade de Buenos Aires, Don Pedro de Cevallos, ordenou que se recolhessem informações sobre a retenção de desertores espanhóis, sobre a "sedução e extração de índios", e roubos e matanças de gado executadas pelos portugueses. O governador teve repetidas vezes notícias de que muitos dos índios e

\footnotetext{
${ }^{65}$ MAEDER, Ernesto J. A. Misiones del Paraguay: conflicto y disolución de la sociedad guaraní. Madri: MAPFRE, 1992; GARCIA, Elisa Frühauf. Op. Cit. 2009, p. 146 e seguintes.

${ }^{66}$ AGS. (Valladolid). Secretaria de Estado, Legajo 7405, documento 71: Quartel General de San Borxa. Año de 1759. Agradeço a Eduardo Neumann pela indicação e por ter proporcionado meu acesso a essa importante fonte histórica sobre a história de São Nicolau do Rio Pardo.
} 
índias que haviam deixado os povos das missões orientais se encontravam nas imediações de Rio Pardo. Preocupado com a perda dos vassalos para o lado português e em saber quais as estratégias usadas para atrair e manter em seu território aqueles que haviam sido seus aliados, Don Pedro de Cevallos ordenou ao general-mor dos Reales Exércitos, Don Diego de Salas, que executasse retenções e interrogatórios no quartel de São Borja. Os depoimentos fornecem informações sobre os índios que chegavam e saíam de Rio Pardo. É importante considerar que a posição estratégica de Rio Pardo e a existência do aldeamento em suas adjacências fizeram com que aquelas paragens fossem escolhidas como um dos destinos preferidos de desertores, índios, índias e 'chinas'. A maioria dos interrogados afirmou que, segundo o que haviam visto, os portugueses davam bom tratamento aos desertores espanhóis e, além disso, concediam também "libertad grande (...), pues ellos andavan como querian de rancho em rancho de china con el seguro de que no se les castigaria, siendo permitido vivir cada uno como queria." ${ }^{\text {} 67}$ Segundo um dos depoentes, os portugueses diziam freqüentemente aos espanhóis que encontravam pelo caminho que fossem a Rio Pardo, onde viveriam com mais liberdade do que entre os espanhóis do outro lado da fronteira. Ainda assim, de acordo com o inquirido, havia desertores arrependidos e que queriam voltar para os exércitos espanhóis. Disse que muitos deles viriam, mas não o faziam por receio dos castigos com os quais os portugueses os ameaçavam:

y que esto mismo sucede con maior rigor a los indios e indias que quieren, o intentan venirse a sus Pueblos, castigando a los que [ilegivel] con las maiores prisiones y severidad, y que para evitar su fuga tienem [ilegível] todos los caminos con varias Guardias en distintos puertos, como el paso de San Lorenzo, y camino de Viamont, y añade que los mismos indios le han dicho que ellos se habian ido con los portugueses, fiados en las ofertas y promesas que les hicieron quando les aconselaron el que se fueran con ellos, pero que despues se habian desengañado, y visto de todo era embuste, y que se hallaban arrependidos e disgustados, y con grandes deseos de volverse a sus Pueblos, y que no lo hacian porque no davan lugar para ello, antes les castigavan com maior rigor si intentava alguno escaparse, como havia sucedido con muchos.

\footnotetext{
${ }^{67}$ AGS. (Valladolid). Secretaria de Estado, Legajo 7405, documento 71: Quartel General de San Borxa. Año
} de 1759. Depoimento de Juan Forales, soldado blandengue da Companhia de Don Miguel Dominguez. 
Pode-se perceber que há certa contradição no que se refere às ameaças portuguesas feitas aos desertores espanhóis e o bom tratamento que os mesmos portugueses lhes davam. É interessante notar, nesse sentido, que todos os dezessete depoentes, quando perguntados sobre as deserções, respondiam sobre os peões, os oficiais do exército, e também sobre os índios e índias que haviam encontrado, considerando a todos como desertores. Nem sempre é possível identificar se os índios eram tidos também como servidores do Exército, tanto pelos depoentes quanto pelos seus argüidores. Do mesmo modo, às vezes não é possível diferenciar as mulheres consideradas 'chinas' das índias. Essas supostas confusões identitárias denotam não somente uma grande mestiçagem entre sujeitos históricos e práticas sociais, como também uma noção de mobilidade espacial que ultrapassa a noção de espaço territorial. Elas conduzem a pistas sobre possíveis maneiras de pensar e agir das pessoas envolvidas nessas situações. Como a idéia de pertencimento e de lealdade à Coroa portuguesa ou espanhola era entendida por esses agentes sociais? As noções sobre pertencimento e as diversas formas de usá-las estrategicamente pareciam se movimentar entre um lado e o outro dos complexos fronteiriços. Percebe-se, através de várias pistas presentes nesse documento, que de acordo com as situações com as quais se deparavam, os índios tinham escolhas a serem feitas. Assim, poderiam se identificar aos, como também ser identificados pelos funcionários do exército espanhol como índios guarani-missioneiros desejosos de retornar aos domínios do rei católico; e aos funcionários do exército português, como desertores espanhóis que, devido ao bom tratamento dado e a liberdade adquirida nos domínios do rei fidelíssimo, não desejavam retornar.

Francisco Cavallero, outro depoente, também era soldado 'blandengue' ${ }^{\text {, }}$ e servidor do exército espanhol. Ele havia voltado de Rio Pardo há poucos dias quando foi retido no quartel de São Borja. Declarou que muitos dos desertores espanhóis se encontravam em Rio Pardo amancebados com 'chinas', dentre eles muitos oficiais que lá viviam como se fossem

\footnotetext{
${ }^{68}$ Sobre a formação do corpo de blandengues: "Cuando el desarollo de los saladeros exija ganados castrados y la explotacóin a rodeo requiera mayor cantidad de mano de obra, cuando disminuyan los cimarrones y el contrabando con Brasil conlleve el robo de las estancias, el Gremio de los Hacendados, organizado en 1797, y la eliminación del banditismo rural. De todas maneras no existió un criterio uniforme de las distintas clases domineras, ni aun entre los hacendados, pues durante largos lapsos el contrabando fronterizo representó un mercado alterno ante la interrupción del tráfico con la metropoli. El Cuerpo de Blandengues, cuya oficialidad se integró en buena parte con hijos de estancieros, su tropa con hombres indultados de delitos menores, y que se costeó con un impuesto a los cueros, fue la fuerza fundamental para imponer el orden de los estancieros en la campaña". TOURON, Lucía Sala de; LA TORRE, Nelson; RODRÍGUEZ, Julio C. Artigas y su revolución agraria 1811-1820. Mexico, Siglo XXI, 1987, p. 34.
} 
casados, "cuyo escandalo era publico e notorio a todos" ${ }^{69}$. Disse que havia conversado com "muchos desertores espanholes conocidos suyos y amigos" que passaram por Rio Grande para chegar a Rio Pardo. Estes haviam lhe contado que, tendo estabelecido contato com os portugueses, passaram a fazer correrias de gado nas estâncias dos 'pueblos de misiones'. As atividades de roubo e matanças de gado lhes agradavam pela liberdade com que julgavam viver, entretanto, alegaram que estavam muito cansados, pois não lhes faltava trabalho. Apesar disso, as condições de sobrevivência eram difíceis, e "se mantenían ayudados de la grasa, sebo y charque que hacian para vender a los pulperos portugueses" ${ }^{70}$. Os índios e índias que viviam em Rio Pardo, segundo o soldado blandengue, desejavam e algumas vezes tentavam retornar aos seus 'pueblos', mas quando descobertos eram castigados severamente. As informações de Francisco Cavallero mostram que as estâncias dos povos das missões estavam sendo constantemente saqueadas por desertores espanhóis, muitas vezes a pedido dos portugueses. Com as estâncias das reduções sendo saqueadas, talvez nem todos os índios estivessem desejosos de regressar aos ditos povos. Pode ser que, para aqueles que optaram por ir a Rio Pardo, essa oportunidade tenha lhes parecido mais vantajosa. O aldeamento de São Nicolau havia sido fundado dois anos antes do recolhimento destes depoimentos (em 1757), mediante negociações estabelecidas entre lideranças indígenas e autoridades portuguesas. Tratava-se de um acordo reconhecido pelo governo do Continente, logo, aquele espaço territorial também pode ter representado um espaço de proteção contra os assaltos e correrias de gado. Por outro lado, a proteção lhes cerceava a liberdade e uma vez fora do aldeamento poderia ocorrer situações em que os índios teriam que pagar pelo preço de ir e vir.

\footnotetext{
${ }^{69}$ AGS. (Valladolid). Secretaria de Estado, Legajo 7405, documento 71: Quartel General de San Borxa. Año de 1759. Depoimento de Francisco Cavallero, também soldado 'blandengue' e servidor do exército espanhol.

${ }^{70}$ IDEM. Año de 1759. Depoimento de Francisco Cavallero, também soldado 'blandengue' e servidor do exército espanhol. Os dois últimos trechos foram retirados deste depoimento.
} 


\section{3 - "PÉS PARA FUGIREM PARA O RIO GRANDE"}

Segundo os relatos deixam transparecer, os exércitos espanhóis não pareciam conseguir controlar as deserções e as investidas estrangeiras contra seus domínios, ao contrário dos portugueses que cooptavam os aliados dos espanhóis (índios e não-índios) e saqueavam seus territórios. No depoimento de outro dos interrogados, o tenente de Dragões do Presídio de Buenos Aires, Dom Francisco Viera, é possível perceber que nem todos os índios praticavam as mesmas ações, tampouco pareciam pensar da mesma maneira ou ter os mesmos sentimentos e desejos de voltar aos seus povos. O tenente foi destacado para uma comissão demarcatória que partiu da missão de São Nicolau, da qual desertaram alguns soldados e peões levando consigo mulas e cavalos para Rio Pardo. Ele disse ter notícias de que tais desertores se encontravam, junto com muitos outros, a fazer correrias de gado ajudados pelos portugueses. De acordo com informações dos próprios portugueses, com quem estivera, "el capitan Pinto se hallaba en la Estancia de San Miguel com ciquenta indios para correr ganado bacuno en otra Estancia" ${ }^{\text {"71 }}$. Devido a ações como essas, as estâncias dos povos das missões estavam inteiramente destruídas e despovoadas de acordo com Don Francisco. Segundo ele, fatos semelhantes aconteciam nas estâncias de São João, São Luiz e São Lourenço.

${ }^{71}$ AGS. (Valladolid). Secretaria de Estado, Legajo 7405, documento 71: Quartel General de San Borxa. Año de 1759. Depoimento de Don Francisco Viera, tenente de Dragões da Província do Prata e cidade de Buenos Aires. 


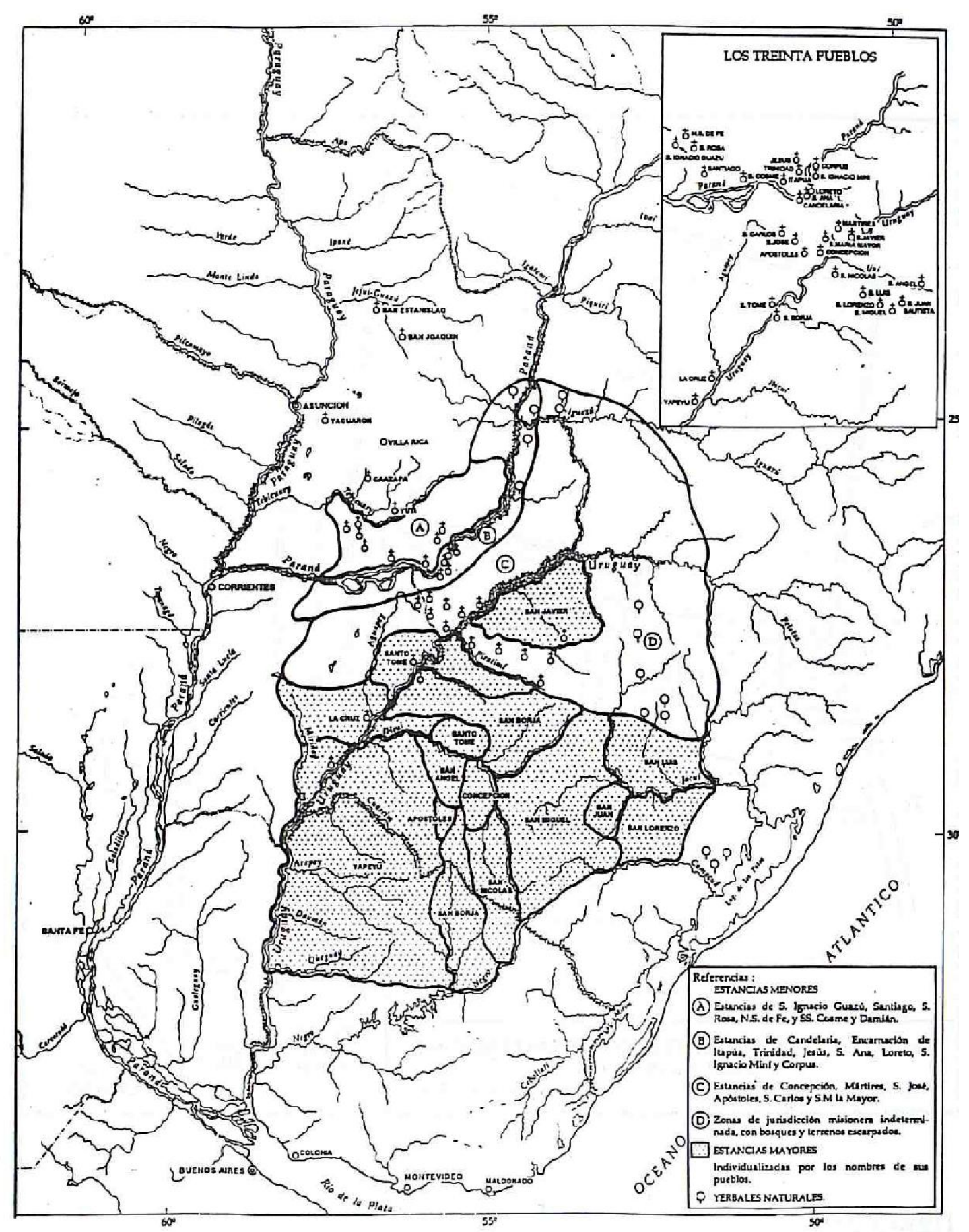

IMAGEM 3 - Mapa do Território dos Trinta Povos Jesuítico-Guarani e suas estâncias.

Fonte: MAEDER, E. \& GUTIERREZ, R. Atlas Histórico y Urbano del nordeste argentino. Resistência, IIGH, 1994. APUD: BARCELOS, Artur H. Espaço \&arqueologia nas missões jesuíticas: o caso de São João Batista. Porto Alegre: EDIPUCRS, 2000, p. 393. 
É possível notar que índios poderiam estar se beneficiando do roubo de gado nas estâncias de outros povos, como parece ser o caso daqueles que se encontravam na companhia do capitão Pinto. Pode ser que estivessem apenas recuperando gados que consideravam ser seus e de suas estâncias. Nesse caso, as ações não figurariam roubo. Essa era a opinião de autoridades interessadas em riquezas materiais que antes pertenciam aos guaranis de missões, como o marquês do Lavradio ${ }^{72}$. Mas o que de fato parece relevante é que muitos dos índios que deixaram os povos das missões orientais, quer fosse para fazer correrias de gado, quer fosse para ir a Rio Pardo, não se encontravam isolados. Eles se relacionavam com os demais agentes sociais, e de acordo com as possibilidades buscavam negociar, podendo tirar algum proveito do conflito gerado pela posse dos territórios em disputa. As posições sociais geradas naquele contexto de complexidade fronteiriça lhes possibilitavam alguma margem de manobra em meio às dificuldades com as quais constantemente se deparavam. Segundo Elisa Garcia ${ }^{73}$,

São Nicolau teve uma importância estratégica na vivência dos índios na divisa entre os Impérios português e espanhol, devido à sua localização na fronteira entre ambos ao longo da segunda metade do século XVIII. A aldeia abrigava os índios que vinham das missões para o Rio Grande e ainda servia como entreposto aos que saíam da aldeia dos Anjos e iam fazer correrias de gado nos domínios castelhanos.

Perguntado sobre os índios que estavam em Rio Pardo e sobre o tratamento que lhes era dispensado, este último depoente respondeu que sabia da existência de vários povos de índios naquele local, nomeados de São Miguel, Santo Ângelo e São Nicolau ${ }^{74}$. Ainda de acordo com Don Francisco Viera, constantemente se 'seduziam' índios e índias da missão de São Miguel para irem a Rio Pardo. Ele foi informado que índios moços daquela missão se encontravam em um rancho na companhia de soldados portugueses. Quando reclamou ao comissário e comandante português daquela partida, o capitão Cardoso, pedindo que entregasse e enviasse os índios para suas missões, o capitão respondeu que os enviaria, mas

\footnotetext{
${ }^{72}$ GARCIA, Elisa Frühalf. Op. Cit. 2009, p. 151.

${ }^{73}$ IDEM, p. 132.

${ }^{74}$ Essa informação condiz com a de outra fonte histórica explorada no capítulo 1.
} 
sob o pretexto de que os índios haviam desaparecido, mandou que os soldados portugueses os enviassem para Rio Pardo. Não havia somente o 'extravio' de índios, mas também de índias. Segundo o tenente, alguns deles lhe fizeram queixas sobre o seqüestro de suas mulheres por soldados portugueses que estavam nas cavalhadas para a comissão demarcatória da qual ele participava. Haviam inicialmente pedido ao mesmo capitão Cardoso que as devolvessem. O capitão disse que iria acatar seu pedido e dar a ordem para que os soldados assim o fizessem. Entretanto, quando os índios localizaram a dita cavalhada para recuperar suas mulheres, perceberam que, em verdade, o capitão as havia escondido em outra, avisando às demais para noticiarem que não sabiam em qual delas as índias estavam. Até o momento do interrogatório, não se tinha "la menor noticia de ellas, quedando los pobres indios desconsolados sin sus mujeres" ${ }^{\prime 75}$. Tais atos de força não eram realizados somente por soldados portugueses.

Um peão desertou da mesma partida demarcatória espanhola levando consigo três índias de São Miguel. O tenente Vieira despachou um oficial para recuperar o desertor e as índias, que seguiu no rastro dos mesmos até a Guarda do Jacuí ${ }^{76}$, já que era quase certo que o destino dos desertores espanhóis era mesmo Rio Pardo. Lá chegando, pediu e recomendou aos soldados que não as deixassem passar, mas que as devolvessem para serem enviadas de volta à missão de São Miguel. Os soldados da Guarda disseram que não as haviam visto passar, nem ao peão. Entretanto, depois de algum tempo, devolveram o desertor espanhol e ficaram com as índias. Pode ser que os soldados as tenham enviado para Rio Pardo, para viverem 'amancebados' com elas, gozando da mesma 'liberdade' que o governo português oferecia aos desertores espanhóis. Nesse caso, elas muito provavelmente poderiam ser identificadas por 'chinas', como várias vezes se mencionou no documento. Não é possível afirmar se esse foi o destino das três índias, mas o certo é que o tenente Viera não se equivocara, e o desertor realmente as estava levando para Rio Pardo.

As mulheres foram agentes fundamentais nas relações que se estabeleceram entre indígenas e não-indígenas. Desempenharam um papel importante nas misturas e nos

\footnotetext{
${ }^{75}$ AGS. (Valladolid). Secretaria de Estado, Legajo 7405, documento 71: Quartel General de San Borxa. Año de 1759. Depoimento de Don Francisco Viera, tenente de Dragões da Província do Prata e cidade de Buenos Aires.

${ }^{76}$ A Guarda do Jacuí controlava a entrada e saída de pessoas de Rio Pardo de acordo com informações da própria fonte.
} 
diversos tipos de interações sócio-culturais que se faziam entre uns e os outros. Naquele contexto, "las interaciones em que se involucraban los guaraníes misioneros poseían una dimensión sexual muy definida. El mestizaje biológico fue una práctica central que se difundió dentro y fuera de los pueblos guaraníes misioneros"77. As mulheres guaranis mantiveram contatos com o cotidiano da sociedade envolvente através de uma prática nada cristã, a poligamia e o 'amancebamento'. Ainda que tais práticas carregassem consigo significados que pareciam ser um tanto exóticos para tal sociedade causando 'escândalo público e notório', parecia se tratar de algo um tanto usual. Para os índios, entretanto, exótico pode ter parecido o costume monogâmico após a expulsão dos jesuítas, quando "se dieron casos de españoles que se mezclaban con mujeres guaraníes"78. Além disso, em outros tempos os guaranis tinham o costume de vincular mulheres a posições sociais de prestígio, e os casamentos a dívidas e dádivas que lhes proporcionavam redes de solidariedade e reciprocidade através do parentesco $^{79}$ :

Os índios da região do Rio da Prata não inseriram os colonos espanhóis em sua lógica do dom: estes já estavam previstos na regra do jogo, apenas sendo aguardada a sua presença. Oferecer uma irmã ao branco era possibilitar, enfim, a aliança parental desejada.

Quanto mais mulheres um homem tinha, mais prestígio ele possuía, principalmente no caso dos caciques. Em meados do século XVIII, é possível que algumas das índias guaranis que foram para Rio Pardo tenham percebido que elas mesmas poderiam acionar redes sociais, através de outras estratégias. Segundo Almir Diniz de Carvalho em seu estudo sobre a Amazônia portuguesa, a permanência das índias em núcleos coloniais poderia ser uma opção melhor do que a de continuar em aldeias jesuíticas. Isso, apesar das muitas e pesadas atividades domésticas para as quais eram designadas e "por mais

\footnotetext{
${ }^{77}$ WILDE, Guillermo. Op. Cit. 2009, p. 299.

${ }^{78}$ IDEM.

79 FELLIPE, Guilherme Galhegos. "A lógica do cuñadazgo: relação de troca e dinâmica cultural”, in V Mostra de pesquisa do Arquivo Público do Estado do Rio Grande do Sul (2007 : Porto Alegre, RS). Anais : Produzindo História a partir de Fontes Primárias / (org.) Vladimir Ferreira de Ávila. - Porto Alegre: CORAG, 2007, p. 20.
} 
contraditório que possa parecer, embora escravas, adquiriram mais liberdade". Tal liberdade não estava restrita ${ }^{80}$

\begin{abstract}
à liberdade sexual, mais principalmente à liberdade de não trabalhar nas roças dos jesuítas e, conseqüentemente, serem obrigadas a cumprir serviços para vários moradores de tempos, em tempos. Pertencendo somente em uma casa, adquiriam vantagens $e$, provavelmente, uma extensão de vida. Os favores sexuais, neste sentido, poderiam ser seu passaporte para a "liberdade".
\end{abstract}

Ao que parece, a prática poligâmica não parecia ser desconhecida e desvantajosa, nem para a sociedade envolvente, nem para os indígenas que se encontraram em Rio Pardo, apesar das sanções impostas pelos costumes religiosos. Isso revela também que designações sociais como desertores e 'chinas' e categorias identitárias como 'índios', ambas encontradas com freqüência nas fontes históricas, bem como as aparentes contraposições que esses conceitos guardam em relação à noção de civilidade, por si só, não consegue abarcar os processos e das dinâmicas históricas. Não basta identificar desertores espanhóis como infratores de códigos de condutas militares, ou como ladrões de gado e cavalos, ou ainda como homens que não eram casados oficial e legalmente vivendo 'amancebados' com 'chinas'. Não se tratava simplesmente de pessoas que viviam como 'foras da lei'. Neste caso, podemos perceber que atos ilegais eram praticados por servidores do exército tanto quanto eram praticados por índios. Do mesmo modo, alguns índios recorreram às autoridades militares no intuito de contornar uma situação que consideravam injusta e ilegal: o roubo de suas mulheres. Assim, vincular a idéia de 'barbárie' à incivilidade e à ilegalidade, não se aplica ao contexto estudado. Nesse sentido, Guillermo Wilde ${ }^{81}$, ao analisar situações semelhantes ocorridas na Província do Prata considera que:

\footnotetext{
${ }^{80}$ CARVALHO, Jr. Almir Diniz de. Índios cristãos: a conversão dos gentios na Amazônia portuguesa (16531769). Campinas, SP, 2005 (Tese de doutorado), p. 262.

${ }^{81}$ WILDE, GUILLERMO. Orden y ambiguidad en la formación territorial del Río de la Plata a fines del siglo XVIII. Horizontes Antropológicos, 2003, ano 9 (19): 105-135.
} 
De las situaciones de ambigüedad creadas por estos movimientos deben haber surgido nuevas categorías de identificación sociocultural de gran flexibilidad y adaptabilidad. No está del todo clara la procedencia del término "guaderío" o "gaucho" pero posiblemente apareció en la segunda mitad del siglo XVIII para referir a la población desarraigada de la campaña que se dedicaba a las actividades ganaderas consideradas "ilegales" y que llevaba un modo de vida que no se ajustaba al canon oficial.

A situação descrita nos depoimentos feitos em 1759 parece ter continuado ao longo do século XVIII. Em 1772, Francisco José da Rocha, um enviado especial do marquês do Lavradio foi incumbido da tarefa de relatar tudo que visse e ouvisse no Continente de São Pedro. Numa carta ao vice-rei avaliava que havia "dois objetos principais neste Governo, que são as corridas de gado de Espanha, para melhor dizer furtos, e o governo dos Índios, que um e outro deixam bastantes lucros para quem os exercita e governa (...)" ${ }^{82}$. Em 1776, o governador do Continente de São Pedro, estava ciente do paradeiro dos índios que fugiam de um aldeamento para outro, e do que esse fluxo significava para a política indigenista da capitania. José Marcelino ponderava sobre os resultados que teria conseguido no governo dos índios, caso não fosse a guerra com os espanhóis e caso não tivessem “(...) os mais índios e índias pés para fugirem para o Rio Grande (...)" ${ }^{83}$. No início do século XIX, um funcionário do Império espanhol também relatava o trânsito dos indígenas e sua "noção de liberdade" em sentido contrário às fronteiras impostas por demarcações territoriais ${ }^{84}$ :

(...) pero lo peor de estas emigraciones es los muchos que se pasan a los dominios de Portugal, perdiendo el Estado estos vasallos y aumentando el poder al extranjero en aquella parte. Las jurisdicciones de Río Pardo, Puerto Alegre y Río Grande están llenas de indios de Misiones (...).

\footnotetext{
${ }^{82}$ ANRJ, Fundo Marquês do Lavradio, Microfilme 024-97, notação 16.76 a 16.78 (Viamão, 27.01.1772).

${ }^{83}$ BNL. Divisão de Reservados. Cód. 10854, carta do governador José Marcelino de Figueiredo ao vice-rei marquês do Lavradio. Porto Alegre, novembro de 1776 [não consta o dia].

${ }^{84}$ DOBLAS, Gonzalo de. Disertación que trata del estado decadente en que se hallan los pueblos de Misiones y se indican los medios convenientes a su reparación. In: TRENTI ROCAMORA, José Luis. Un Informe inédito de Gonzalo de Doblas sobre la emergente situación de Misiones en 1801. Santa Fé: Departamento de Estudios Coloniales: Castelvi, 1948. Apud WILDE, Guillermo. "Orden y ambigüedad en la formación territorial del Río de la Plata a fines del siglo XVIII", Horizontes Antropológicos, Porto Alegre, ano 9, n.19, p.105-135, julho de 2003.
} 
Segundo Guillermo Wilde, tratava-se de uma situação que há muitos anos era comum aos povos guaranis-missioneiros da região e que, sobretudo, revelava "la debilidad del concepto de Estado para la población de la campaña que había hecho de la fuga y la movilidad estrategias fundamentales" ${ }^{\$ 5}$. São Nicolau do Rio Pardo se situava numa região de conflito, onde havia diferentes interesses, em busca da definição de limites territoriais. Tais limites ainda não haviam sido definidos e os indígenas se encontravam em zonas fronteiriças, nas quais circulavam indivíduos, modos de agir e bens materiais e simbólicos. De acordo com os apontamentos de Guillaume Boccara, novos interesses pelo estudo dos complexos fronteiriços têm sido despertados a partir da aproximação entre a história e a antropologia $^{86}$ :

el estudio de la dinámica fronteriza aporta nuevas luces sobre la política expansionista española y sobre el funcionamento del estado colonial; y, finalmente, porque esas zonas fronterizas - en el seno de las cuales circulaban indivíduos, ideas e objectos - constituyen un inmenso 'laboratorio' para el estudio de los procesos de mestizaje y de la creación de nuevos sujetos históricos.

Conforme dito anteriormente, há raros trabalhos que abordam histórias que incluem os guaranis como personagens históricas no século XIX. A maioria deles possui como recorte temporal a segunda metade do século XVIII. Assim, parece ser interessante analisar como e por que a aldeia de São Nicolau do Rio Pardo teria conseguido sobreviver ao longo do período oitocentista, sem colocar de lado, é claro, a trajetória anterior do aldeamento e o conjunto das ações indígenas que podem explicar sua notável perenidade. A próxima parte aborda outras conjunturas e as novas respostas elaboradas para situações vividas no século XIX.

\footnotetext{
${ }^{85}$ WILDE, Gullermo. Op. Cit. 2003, p. 118.

86 BOCCARA, Guillaume. "Etnogénesis mapuche: resistência y restructuración entre los indígenas del Centro-Sur de Chile (siglos XVI-XVIII)”, Hispanic American Historical Review, 79:3 (1999), pg. $425-426$.
} 


\section{4 - OUTROS TEMPOS, OUTROS CONTATOS}

"Año de 1823 roy pipe chaci febrero pe omanõ curumi Joã(o) Pasqual Arazuc he a pipe jojexubá Tupã (t)a ñderú avõ Maria"

Dizeres gravados em um tijolo que faz parte do acervo do museu Barão de Santo Ângelo, na cidade de Rio Pardo.

No ano de 2000, um vetusto prédio situado à esquina das ruas Artur Falkenbach e Mateus Simões, no centro da cidade de Rio Pardo, estado do Rio Grande do Sul, foi demolido. Durante a obra, pessoas que trabalhavam no local encontraram um tijolo com escritos que não compreenderam. Hoje o material faz parte do acervo do museu Barão de Santo Ângelo e está exposto logo na sua entrada ${ }^{87}$. As palavras gravadas em guarani e espanhol foram traduzidas livremente e se encontram em placa explicativa ao lado do mesmo: "Ano de 1823 ocorreu o passamento por doença do curumi (menino) João Pascual Arazuc. Repouse em Tupã (Deus) Nosso Senhor! Ave Maria!”. A palavra ano significa roy em guarani, chaci (jacy/jaxy) significa lua e ambas foram usadas para contar e marcar o tempo. Omanõ significa morrer, ñderú significa deus ${ }^{88}$.

Os escritos do tijolo suscitam uma série de aspectos importantes acerca das histórias de índios guaranis que habitaram e circularam pelos territórios do sul do Brasil. Essa fonte histórica traz à tona antigas questões que já foram objeto de análise de vários autores em estudos importantes, alvos de várias polêmicas ${ }^{89}$. Elas dizem respeito a circulação e a

\footnotetext{
${ }^{87}$ É preciso levar em conta que o objeto foi encontrado durante a realização de uma obra civil, na qual não havia a presença de arqueólogos ou historiadores. Não se sabe ao certo em que condições o objeto foi encontrado e trazido ao museu. Mas, para o historiador, é relevante o fato de que o tijolo foi reconhecido como uma fonte histórica e passou a fazer parte do acervo de um dos museus da cidade.

${ }^{88}$ Agradeço a Vherá Poty Benites da Silva e a Graciela Chamorro por terem me ajudado com a tradução do texto. Informo que a grafia das palavras não está de acordo com a grafia atual do dialeto mbyá-guarani.

${ }^{89}$ MONTEIRO, John Manuel. "Os Guarani e a história do Brasil Meridional, séculos XVI-XVII". In: História dos índios no Brasil. Org. Manuela Carneiro da Cunha. São Paulo: Companhia das Letras: Secretaria Municipal da Cultura: FAPESP, 1992, p. 475. O autor se refere aos "importantes trabalhos de Alfred Métraux, Pierre Clastres, Hélène Clastres, Branislava Susnik e Bartolomé Meliá" onde a "articulação entre observações históricas e etnográficas tem um duplo significado: se, por um lado, os dados etnográficos têm completado informações ausentes nas fontes escritas, por outro, as mesmas fontes históricas têm dado origem a novas
} 
mobilidade espacial dos guaranis; sua religião, religiosidade e as mudanças que as mesmas atravessaram; bem como as enfermidades, que provocaram baixas demográficas entre as populações guaranis desde os primeiros séculos de contato. Coloca-se em xeque uma informação constantemente veiculada em livros de história sobre os índios em geral, a de que eles não deixaram registros escritos sobre seu passado.

perspectivas sobre a cultura guarani, especialmente com respeito à demografia, à organização política, ao profetismo, aos movimentos espaciais de cunho religioso e mesmo à filosofia (Viveiros de Castro, 1985)" . 


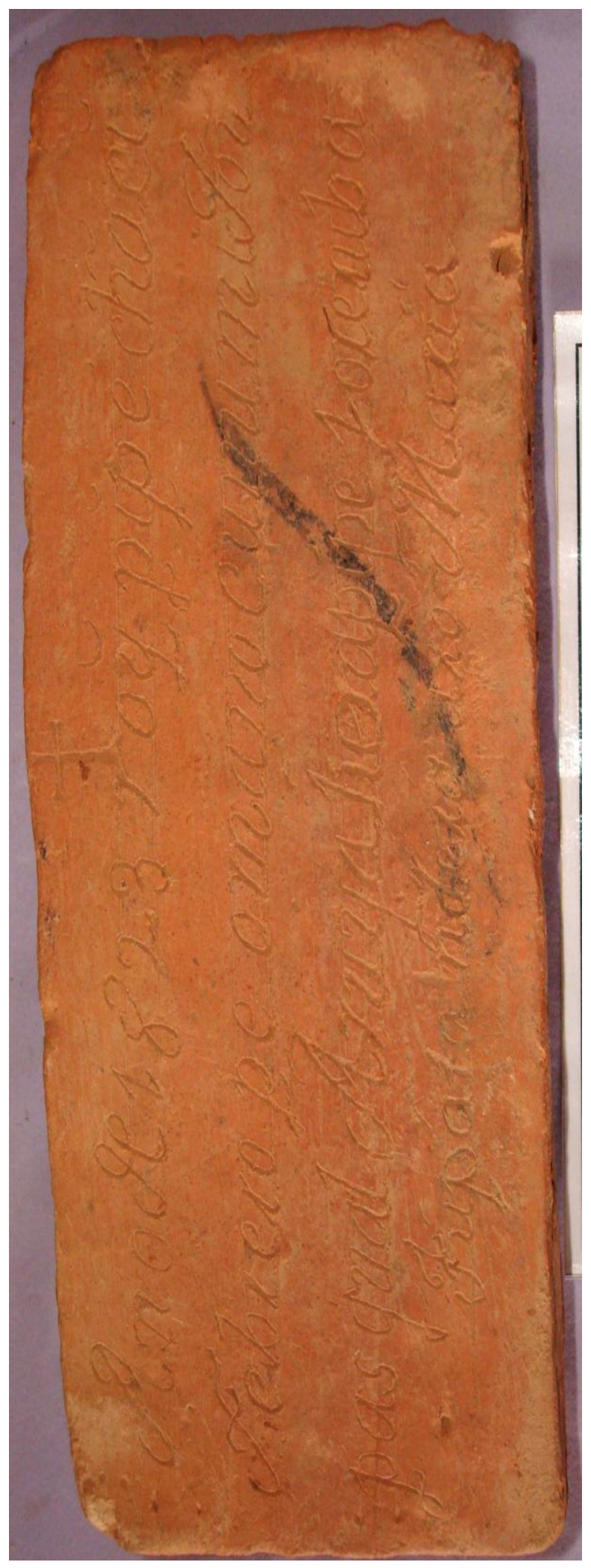

IMAGEM 4 - Tijolo com dizeres gravados em língua guarani e espanhola.

Fonte: Museu Barão de Santo Ângelo, na cidade de Rio Pardo. 
A aldeia de São Nicolau foi fundada em 1757 e extinta na década de 1860. Sim, sua longevidade durou mais de um século, e creio não ter sido superada por nenhum outro aldeamento indígena na história do Rio Grande do Sul. Em seu território houve inúmeros acontecimentos que influenciaram a vida e o destino não só de seus habitantes, mas também aspectos importantes da própria história do Continente e da Província de São Pedro. No ano de 1823, nos arredores da vila e do aldeamento um menino guarani faleceu por doença, de acordo com as informações grafadas no tijolo. Mas que doença teria tirado a vida de João Pasqual? Quem teria se preocupado em deixar um epitáfio sobre sua morte? Por que o teria escondido em meio às paredes de um dos tantos casarões oitocentistas de Rio Pardo? Teriam morado na vila de Rio Pardo e/ou na aldeia de São Nicolau? Possuiriam parentes em ambos os lugares? Estaria trabalhando na construção do casarão quando João Pasqual faleceu? Onde e com quem teria aprendido a ler e a escrever em língua guarani?

Para entender as ações dos indígenas frente às situações com as quais se depararam e os processos de formação de suas identidades, nos quais eles também se posicionaram, é necessário tentar compreender o que eles sentiram, como pensaram e o que fizeram com as suas vidas e com os limites que foram impostos a elas. Certamente, São Nicolau do Rio Pardo não teria sobrevivido por tanto tempo se os sujeitos que o compuseram não tivessem pensado e agido. Mas não era exatamente isso que se pensava sobre os guaranis naquela época. Em meados do século XIX, um médico alemão viajou pela Província de São Pedro visitou São Nicolau do Rio Pardo e deixou um registro sobre suas impressões ${ }^{90}$ :

são indubitavelmente seres humanos provisórios. Tal como os indivíduos é o conjunto! E assim é também a aldeia de São Nicolau um estabelecimento para esses retardados, onde lentamente, preguiçosamente vegetam sua vida de lêmures sem nada fazer, nada pensar, nada sentir!

Há diferentes maneiras de construir, criar e interpretar metáforas e histórias. AvéLallemant pôs em questão o caráter permanente da humanidade dos índios, considerando-a provisória. É de se chamar a atenção as reiteradas tentativas do viajante de transformar a

${ }^{90}$ AVÉ-LALLEMANT, Robert. Op. Cit. 1980, p. 168-169. 
presença humana dos índios em algo invisível. Segundo ele, o silêncio no aldeamento era tumular, a existência era incolor e os índios viviam suas vidas como se fossem fantasmas ou almas errantes ${ }^{91}$ que não agem, não pensam e não sentem. $\mathrm{O}$ discurso e as idéias de Avé-Lallemant estão profundamente marcados pelas questões políticas e sociais do tempo em que ele viveu. É importante contextualizá-los e transpor os discursos que tentaram invisibilizar as ações dos índios. A intenção do presente estudo é oferecer subsídios para isso. Como vimos durante a primeira parte deste capítulo, o aldeamento de São Nicolau do Rio Pardo foi formado num contexto marcado por litígios fronteiriços e territoriais, e por variadas dinâmicas étnicas e sociais. Ele foi o mais duradouro na história do Rio Grande do Sul e podemos destacar os três primeiros quartéis dos oitocentos como um período marcante em sua trajetória. As disputas pelas terras do aldeamento foram intensas, como se verá no próximo capítulo. O envolvimento e a atuação dos índios em guerras foram constantes e diferentes. Ao mesmo tempo, circularam discursos que possuíam uma forte tendência em apagar suas ações. Todas essas questões e as boas pistas que as fontes históricas encontradas fornecem são importantes para reconstruir histórias e trajetórias indígenas, como também para retomar a metáfora empregada por Avé-Lallemant e situá-la à luz de novos apontamentos.

Se o viajante considerou que os índios de São Nicolau do Rio Pardo não praticavam ações como fazer, pensar e sentir, atribuindo o que entendia por apatia e retardamento a comportamentos inerentes ao conjunto dos indivíduos que partilhavam daquela cultura indígena, há o argumento de que essas informações não condizem com o conteúdo das fontes analisadas. O antropólogo Marshall Sahlins chama a atenção para o uso de 'metáforas históricas e realidades míticas' ao interpretar "um mundo onde as pessoas agem de formas distintas e de acordo com suas respectivas situações como seres sociais, condições essas tão comuns à ação numa dada sociedade como à interação entre as

\footnotetext{
${ }^{91} \mathrm{O}$ significado da palavra lêmure pode ser atribuído à alma de pessoas mortas, que segundo a crença dos antigos romanos, atormentavam os vivos. Site de referência: http://www.dicionarioweb.com.br/1\%C3\%A9mures.html., consultado dia 22/04/2010. Na Roma anterior à fé em Cristo, celebravam-se festas em honra às almas dos mortos que erravam pelo mundo, causando pavor aos homens. As festas se chamavam Lemúrias e as almas errantes lêmures. BORGES, Jorge Luis; GUERRERO, Margarida. O livro dos seres imaginários. $8^{a}$ edição. Editora: Globo. 2000.
} 
sociedades distintas" 92 . Segundo ele, a idéia de apresentar transformações culturais mediante a análise da dialética entre estrutura e prática é a de que os seres humanos agem face às circunstâncias, de acordo com seus próprios pressupostos culturais e categorias socialmente dadas de pessoas e de coisas ${ }^{93}$. Nesse sentido, a integração diferencial das pessoas com as formas de poder, afeta as percepções e as condutas de uns em relação aos outros, e se "desdobra num movimento contínuo e recíproco entre a prática da estrutura e a estrutura da prática" 94 . Houve em São Nicolau indivíduos com posturas e práticas que se diferenciavam, embora a maioria do conjunto de seus moradores e integrantes fosse composta por índios guaranis. Apesar de partilharem dos mesmos pressupostos culturais, eles agiram através de diferentes meios e de acordo com as distintas situações com que se depararam.

Embora tenha tentado invisibilizar as ações dos índios, a metáfora utilizada por Avé-Lallemant possui conteúdos históricos que são importantes para entender os pensamentos e as idéias que se expressavam em práticas com as quais os guaranis se confrontaram. Dessa forma, suas palavras não devem ser vistas apenas como um testemunho a respeito do comportamento cultural dos índios. O conteúdo do diário de viagem e das metáforas escritas pelo viajante alemão não devem ser interpretados como algo dotado de caráter exclusivamente poético, como costuma acontecer em interpretações de discursos históricos sobre os índios em geral. Afinal, assim estaríamos fazendo como os poetas gregos e romanos, que ${ }^{95}$ :

pensaram a alegoria como ornamentação de discursos produzidos numa prática forense e poética, prática regida por preceitos que, por serem convenções evidenciavam justamente seu caráter particular de prática e, assim, o valor imanente do discurso produzido.

\footnotetext{
${ }^{92}$ SAHLINS, Marshall. Metáforas Históricas e Realidades Míticas: estrutura nos primórdios da história do reino das ilhas Sandwich. Rio de Janeiro: Zahar, 2008, p.17.

${ }^{93}$ IDEM, Capítulo II, Transformação: estrutura e prática. p. 69-124.

${ }^{94}$ IDEM. Op. Cit. 2008, p. 133.

95 HANSEN, João Adolfo. Alegoria: construção e interpretação da metáfora. São Paulo, SP: Hedra; Campinas, SP: Editora da Unicamp, 2006, p. 23. Ainda segundo o autor, não podemos esquecer que a interpretação grego-romana das metáforas era exclusivamente lingüística.
} 
O valor dos discursos não é imanente. Ele muda ao longo do tempo, assim como as ações dos sujeitos históricos. Tampouco poderíamos analisar a metáfora de Avé-Lallemant como fariam os teólogos da idade média, para os quais a alegoria não era um modo de expressão verbal (como era para os poetas gregos e romanos), mas um modo de interpretar religiosamente os homens e os eventos. Para os teólogos medievais a alegoria tinha por "pressuposto algo estranho à retórica da Antiguidade greco-romana, o essencialismo" 96 , motivo pelo qual a pensaram primeiramente como um ato de discurso, para depois congelála como estrutura, generalizando anacronicamente o seu significado para todo e qualquer tempo. Sobre os usos de metáforas feitos durante a idade média, o historiador Carlo Ginzburg faz reflexões interessantes sobre as idéias de um moleiro friulano perseguido pela inquisição ${ }^{97}$ :

Com inconsciente desenvoltura servia-se de vestígios de pensamentos alheios como de pedras e tijolos. Porém, os instrumentos lingüísticos e conceituais com os quais tomou contato não eram neutros nem inocentes. Aqui está a origem da maior parte de suas contradições, incertezas e incongruências de seus discursos.

Existem vários tipos de discursos que, desde o período quinhentista até os dias de hoje, empregaram metáforas para interpretar e explicar as ações dos índios. Há também apontamentos importantes sobre retórica ${ }^{98}$, história e historiografia onde se salientam aspectos às vezes pouco observados na interpretação desses textos históricos, como "regulações discursivas próprias do seu contexto de produção, em especial regulações oriundas da preceptiva retórica e, em menor medida, da gramática" 99 . Há novos e

\footnotetext{
${ }_{97}^{96}$ IDEM, Op. Cit. 2006, p. 11.

${ }^{97}$ GINZBURG, Carlo. O Queijo e os Vermes: o cotidiano e as idéias de um moleiro perseguido pela Inquisição. São Paulo, Cia. das Letras, 2006, p. 107.

${ }^{98}$ IDEM. p. 142. Ginzburg expõe aspectos sobre 'as figuras de retórica' e seus usos no contexto analisado durante a idade média.

99 ARAÚJO, Sarissa Carneiro. "A história (1576) de Gândavo: notas para uma releitura desde a retórica e a gramática" in Lócus: revista de História, Juiz de Fora, v. 15, n. 2, 2009, p. 72. Dossiê Saúde: profissões, ciências e políticas públicas. Analisando a obra Historia da provincia sãcta Cruz a que vulgarmente chamamos Brasil, publicada em Lisboa, em 1576, a autora chama a atenção de que "a retórica foi, por mais de dois milênios, o código fundamental do qual se gerou todo o texto". Desse modo, considero importante levar em conta a existência de aspectos retóricos presentes em alguns textos históricos oitocentistas, como este de Avé-Lallemant.
} 
importantes estudos que fazem uso da interpretação de textos históricos sobre os índios ${ }^{100}$. Alguns deles indicam que as ações indígenas não são imutáveis. Atos e discursos mudam a cada tempo e mediante distintas situações. Se às palavras de Avé-Lallemant não fosse atribuído valor histórico, serviria apenas para o propósito de legitimar ou invalidar um tipo de discurso sobre os índios guaranis no século XIX, quando discursos possuem histórias a serem contadas ${ }^{101}$ :

La experiencia es el elemento formativo de nuestra consciência. La experiencia se vive como un 'pensamiento, deseo, palabra e imagen y es la realidad primaria. (...) Estas experiencias se manifiestan a través de rituales, teatro, ceremonias y narrativas. Deben actuarse y, por médio de este proceso, los participantes viven y vuelven a experimentar su identidad/diferencia cultural. Estos textos actuados, o experiencias, son unidades de significado socialmente construidas (...).

Logo, para os propósitos dessa pesquisa, e de acordo com seus referenciais teóricos e metodológicos, trata-se de usar os textos e as metáforas para contextualizar as práticas e os discursos nos quais os índios de São Nicolau do Rio Pardo estiveram envolvidos, dando visibilidade às suas ações, e à medida do possível, aos pensamentos e sentimentos que as guiaram. Segundo João Pacheco de Oliveira, mudanças advindas das relações sociais estabelecidas mediante situações de intenso contato, como era o caso dos guaranis de São Nicolau do Rio Pardo, ocasionariam "modalidades de adaptação mútua, interdependência e dominação, sem no entanto suprimir as diferenças nos modos próprios de pensar, sentir e

\footnotetext{
${ }^{100}$ Aqui vale a pena remeter a um exemplo de análise antropológica clássica que faz uso de metáforas usadas por alguns missionários quinhentistas e seiscentistas sobre os índios designados 'Tupinambá'. Ver CASTRO, Eduardo Viveiros de. A inconstância da alma selvagem - e outros ensaios de antropologia. São Paulo, Cosac \& Naify, 2002, Capítulo III, O mármore e a murta: sobre a inconstância da alma selvagem, p. 181-264. Segundo Eduardo Viveiros de Castro, "Dizer, como fizeram a seu modo os jesuítas, que a resistência tupinambá ao cristianismo não se devia à sua religião, mas à sua cultura, não ajuda muito. Pois nós, modernos e antropólogos, concebemos a cultura sob um modo teológico, como um 'sistema de crenças' a que os indivíduos aderem, por assim dizer, religiosamente". E ainda: "Entendemos que toda sociedade tende a perseverar no seu próprio ser, e que a cultura é a forma reflexiva deste ser; pensamos que é necessário uma pressão violenta, maciça, para que ela se transforme. Mas, sobretudo, cremos que o ser de uma sociedade é seu perseverar: a memória e a tradição são o mármore identitário de que é feita a cultura. Estimamos, por fim, que, uma vez convertidas em outras que si mesmas, as sociedades que perderam sua tradição não têm volta". Essas duas citações encontram-se respectivamente nas páginas 191 e 195. O grifo é meu.

${ }^{101}$ RODRÍGUES, Mariângela. Tradición, identidad, mito y metáfora: mexicanos y chicanos en Califórnia. Ciudad de México. Ed. Miguel Angel Porrúa, 2005, p. 31.
} 
agir tornadas agora como mais sutis e difíceis de captar" ${ }^{\prime 102}$. Concordo com ele, pois as palavras escritas no tijolo indicam formas de adaptação mútua de uma cultura à outra, como a influência do espanhol na escrita em língua guarani ou a presença da religiosidade indígena em meio à prática que possui características cristãs. As palavras año, em espanhol, e roy (ano) e chací (lua) em guarani foram usadas simultaneamente como forma de perceber, contar e marcar o tempo. A invocação à Tupã, Ñderú e à Maria, mãe de Cristo, indicam pensamentos criativos e mestiços. Revelam também modos próprios de expressar sentimentos. O tijolo aponta a presença de índios guaranis em espaços urbanos e lança luzes sobre as possíveis ocupações dos índios na vila de Rio Pardo durante o século XIX. Até o momento, entretanto, nenhum outro registro sobre o curumim João Pasqual foi encontrado ${ }^{103}$. Parte de sua história e a de quem prestou homenagem à sua morte permanece um mistério. Mas é possível conhecer parte da história de muitos outros guaranis e acompanhar a trajetória do território onde eles estiveram presentes durante boa parte do período oitocentista. Ao mesmo tempo, o estudo sobre São Nicolau do Rio Pardo oferece pistas através das quais é possível constatar a presença dos índios em vários outros lugares fora do aldeamento, revelando aspectos interessantes sobre sua mobilidade espacial. Vejamos, então, situações onde tal mobilidade esteve ligada às enfermidades e às políticas indigenistas. Também é interessante refletir sobre os objetos e os saberes que circularam naquele contexto.

Em 1849, o diretor geral dos índios escreveu sobre uma doença que acometia os guaranis de São Nicolau do Rio Pardo. Entre as medidas que julgava necessárias para "chamar ao centro da civilização esses restos dos primeiros habitantes dos nossos pagos", ele sugeriu o deslocamento dos índios para outro lugar em virtude da elefantíase. Lamentou que a doença estivesse se desenvolvendo no aldeamento e pediu providências ${ }^{104}$ :

\footnotetext{
102 OLIVEIRA, João Pacheco de. "O nosso governo”: os Ticuna e o regime tutelar. São Paulo. Marco Zero; Brasília: MCT/CNPq, 1988, p. 265.

${ }^{103}$ Fontes paroquiais ainda não foram consultadas.

${ }^{104}$ AHRS. Fundo Indígenas. Diretoria de Geral dos Índios. Aldeia de São Nicolau. Correspondência ativa de José Joaquim de Andrade Neves, maço 3, 1849. Estes dois trechos foram retirados dessa mesma fonte.
} 
a fim de ver-se não continuar tão terrivel mal e parece-me acertado que estes enfermos fossem auxiliados com sustento e transportes e levados às águas minerais de Santa Maria da Boca do Monte, onde consta que iguais doentes tem melhorado. Sua conservação na aldeia é bastante prejudicial.

Segundo o diretor geral dos índios, a permanência dos doentes no aldeamento lhes era prejudicial, sendo necessário que se deslocassem a fim de obter cuidados e tratamento em outro lugar. As águas minerais de Santa Maria da Boca do Monte se localizavam junto a serra do Botucaraí, na qual havia uma estância chamada Rincão da Boca do Monte. Auguste Saint-Hilaire, conhecido cientista francês que viajou pela Província de São Pedro nos anos de 1820 e 1821, passou pela referida estância. Consta em seu relato, que ele foi recebido por um morador das vizinhanças. Ao contrário do diretor geral dos índios, o morador considerava não haver benefício algum para aqueles que se deslocavam para as terras da serra da Boca do Monte. Ele se lastimava de que "tanta gente deixe suas terras para se estabelecer aqui, onde cometem tantas extravagâncias pelas índias e não se enriquecem nunca" ${ }^{105}$. Segundo Saint-Hilaire, nessa estância havia algumas aldeias de índios, que eram mal vestidos e ${ }^{106}$

as mulheres não possuem sequer uma coberta para protegê-las contra o frio. Elas o suprem colocando brasas sob o leito que, como já relatei, se compõe de um quadro guarnecido de tiras de couro cruzadas. É dessa maneira que se aquecem os doentes (...).

Os índios pareciam não possuir muitos recursos. Segundo este morador, muitos homens iam para a serra da Boca do Monte, se apaixonavam pelas índias e não queriam mais deixá-las. "Como uma espécie de encantamento" ele falou "sobre o amor que as índias inspiram aos brancos" ${ }^{107}$. Não se sabe se os homens que deixaram suas terras, como os de São Nicolau do Rio Pardo, o fizeram por vontade própria ou por imposição. Mas é interessante observar a possibilidade de haver ligações entre o advento das doenças, $o$

\footnotetext{
105 SAINT-HILAIRE, Auguste. Op. Cit. 2002, p. 393.

${ }^{106}$ IDEM, p. 394.

${ }^{107}$ IDEM, p. 393.
} 
tratamento delas e o 'amor que as índias inspiravam' aos homens. Se algumas doenças, e o modo como elas eram tratadas pelas autoridades provinciais, foram em parte responsáveis pela mobilidade espacial de alguns índios; o modo de agir das índias e os costumes usados no tratamento daquelas pode ter contribuído não só para curá-las, mas para promover a fixação de homens na região do Botucaraí, inclusive os próprios índios de São Nicolau do Rio Pardo. Não é raro encontrar em fontes históricas da época a presença de doentes junto às índias: “Ausentes, o capataz e os peões dessa estância e não há aqui senão um doente e algumas índias, por sinal muito atraentes" ${ }^{108}$. Outras doenças, no entanto, acabaram por fazer com que alguns índios morressem no aldeamento ou ficassem, por algum tempo, presos a ele. Em 1865, a Câmara Municipal de Rio Pardo informava que havia atendido ao ofício sobre o surto de varíola em caráter de urgência. O vereador João Luis Gomes expôs que o diretor de São Nicolau do Rio Pardo manifestava ${ }^{109}$

o estrago que o flagelo das bexigas tem feito nos índios indigentes da aldeia de São Nicolau, já havendo oito deles sucumbido a semelhante flagelo, e de ter, V. Senhoria, os que estão acometidos do referido mal em uma só casa para melhor tratamento.

A varíola, que também é conhecida por 'bexiga', é uma doença infecto-contagiosa. Ela foi responsável pela morte de várias populações ameríndias desde os primeiros tempos de contatos. O diretor manteve os doentes na aldeia, todos dentro de uma única casa, medida que julgou necessária para melhor tratá-los. Não se sabe como era feito tal tratamento, já que o mesmo diretor alegava haver falta de recursos mesmo para as necessidades mais urgentes desses índios. Deliberou-se que o diretor estava autorizado a chamar o cirurgião do aldeamento e que seus serviços seriam pagos pela Câmara. É interessante o fato de que, em 1849, quando houve elefantíase entre os guaranis de São Nicolau do Rio Pardo, a diretoria geral dos índios solicitou a contratação de dois cirurgiões

\footnotetext{
${ }^{108}$ IDEM, p. 328.

109 AHMRP. Fundo Câmara, Série Correspondência. Livro de Correspondências No3. Paço da Câmara Municipal de Rio Pardo, 23 de dezembro de 1865.
} 
à presidência da província. Um para o aldeamento de São Nicolau e outro para os de Nonoai e Guarita, estes últimos compostos por índios coroados ${ }^{110}$ :

Torna-se muito necessário a nomeação de dois cirurgiões, um na aldeia de São Nicolau e outro para as aldeias de Nonoai e Guarita, encarregado aquele de introduzir a vacina nestes dois pontos.

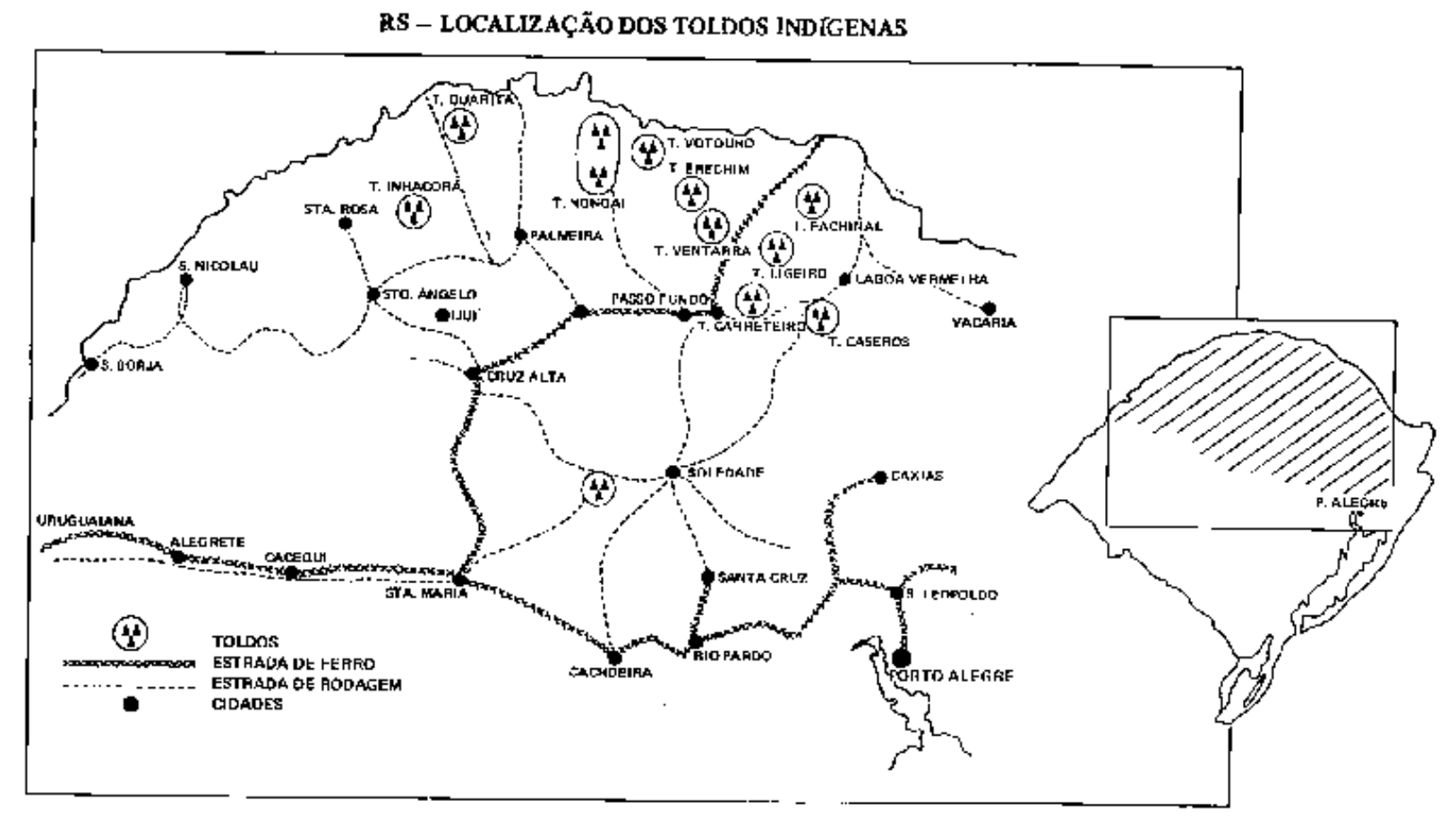

IMAGEM 5 - Mapa dos toldos indígenas no Rio Grande do $\mathrm{Sul}^{111}$.

Fonte: KLIEMANN, Luiza H. Schmitz. Op. Cit. p. 128.

${ }^{110}$ AHRS. Fundo Indígenas. Diretoria de Geral dos Índios. Aldeia de São Nicolau. Correspondência ativa de José Joaquim de Andrade Neves, maço 3, 1849.

${ }^{111}$ Embora o mapa seja referente aos toldos indígenas existentes no começo do século XX, nele é possível visualizar os aldeamentos de Nonoai e Guarita, bem a cidade de Rio Pardo, distante cerca de $6 \mathrm{~km}$ da aldeia. 
As autoridades eram cientes do contato que havia entre os índios de distintos aldeamentos, fossem eles guaranis ou coroados. As doenças ocorreram nesses aldeamentos, indício de que os índios relacionavam-se entre si e circulavam em outros territórios. Para o caso do surto de varíola, em 1865, a doença era contagiosa e as autoridades políticas optaram por proceder ao tratamento na própria aldeia, oposto do que ocorrera antes com os doentes de elefantíase. As doenças não foram as únicas causas das mobilidades espaciais dos índios ou o resultado delas. Ora promoviam seu deslocamento para outros lugares, ora sua permanência dentro do aldeamento. Os distintos tratamentos empregados na cura das mesmas também não foram as únicas experiências pelas quais os índios passaram em função do contato e do contágio. Muitos sujeitos e objetos circularam entre eles, inclusive provenientes dos aldeamentos formados por índios coroados. Ou seja, as mestiçagens e as trocas culturais foram intensas. Movimentaram-se pessoas, doenças, vestimentas, armas, ferramentas agrícolas e saberes culturais. Em 1848, o diretor geral dos índios informou ao presidente da Província sobre ${ }^{112}$ :

a necessidade de obter-se alguns animais para a condução de objetos de uns para outros pontos dos aldeamentos, sobre cujo objeto igualmente espero que $V$. Ex. se digne prover com alguns recursos ou ordenar a compra dos que forem indispensáveis para esse serviço bem como também resolver acerca da requisição dos machados e foices (...).

José Joaquim de Andrade Neves ${ }^{113}$ se referia à circulação de objetos utilizados nas atividades agrícolas realizadas pelos índios. Eles recebiam alguns gêneros alimentícios da presidência da província, os mais comuns eram rações de carne. Mas aqueles que permaneciam nos aldeamentos costumavam plantar principalmente feijão, milho e mandioca. No caso dos índios de São Nicolau, também possuíam algumas reses nos pastos do aldeamento. A circulação de objetos entre os aldeamentos de Guarita, Nonoai e São Nicolau do Rio Pardo não era rara. Certa vez, índios requereram junto à diretoria geral dos

\footnotetext{
${ }^{112}$ AHRS. Fundo Indígenas. Diretoria de Geral dos Índios. Aldeia de São Nicolau. Correspondência ativa de José Joaquim de Andrade Neves, maço 2, 1848. Rio Pardo, 11 de setembro de 1848.

${ }^{113}$ José Joaquim de Andrade Neves foi uma destacada figura política em sua cidade natal, Rio Pardo (18071869). Atuou como militar durante a guerra Farroupilha, a guerra de Rosas e a guerra do Paraguai. Recebeu o título de barão do Triunfo.
} 
índios, sediada em Rio Pardo, o pagamento referente ao frete de suas carretas usadas para transportar objetos de um aldeamento para outros ${ }^{114}$. Mas havia outros objetos, além de machados e foices, que circulavam entre eles. Também em 1848, Andrade Neves solicitava que a presidência da província aprovasse o ressarcimento de uma despesa que ele havia feito com recursos próprios para um casal de índios coroados vindos do aldeamento de Nonoai para São Nicolau do Rio Pardo. Os motivos da vinda do casal e das despesas terem sido feitas pessoalmente pelo diretor geral dos índios são difíceis de descobrir. No entanto, além da presença de índios que não eram guaranis no aldeamento é interessante observar quais foram os "diversos objetos por mim comprados nesta cidade a Lisboa e Irmão para suprimento de um casal de indígenas que aqui se achavam vindos da aldeia de Nonoai" ${ }^{115}$. A lista dos objetos, encaminhada à presidência da Província é curiosa ${ }^{116}$ :

Rio Pardo, 30 de abril de 1848.

O brigadeiro José Joaquim de Andrade Neves

A Lisboa e Irmão comprou

Para um casal de bugres do aldeamento de Passo Fundo

5 camisas de baetas cor de rosa

6 (pares/varas) de algodão largo

24 camisas de chita

1 xale escarlate francês

3 camisas de chita

1 calça de algodão trançado

1 calça de algodão riscado em cetim

2 lenços

1 chapéu de Braga

\footnotetext{
${ }^{114}$ AHRS. Fundo Indígenas. Diretoria de Geral dos Índios. Aldeia de São Nicolau. Correspondência ativa de José Joaquim de Andrade Neves, maço 2, 1848. Rio Pardo, 30 de dezembro de 1848.

115 AHRS. Fundo Indígenas. Diretoria de Geral dos Índios. Aldeia de São Nicolau. Correspondência ativa de José Joaquim de Andrade Neves, maço 2, 1848. Rio Pardo, 30 de agosto de 1848.

${ }^{116}$ AHRS. Fundo Indígenas. Diretoria de Geral dos Índios. Aldeia de São Nicolau. Correspondência ativa de José Joaquim de Andrade Neves, maço 2, 1848. Rio Pardo, 30 de agosto de 1848 (outro documento).
} 
1 enfiado de contas

1 tesoura grande

1 faca

Num total de $32 \$ 760$ réis .

Se os objetos foram mesmo destinados ao casal de vindo de Nonoai (também conhecido por aldeamento de Passo Fundo), caberia questionar quem eram esses índios e o que faziam em São Nicolau do Rio Pardo. Por que foram tratados com tamanho empenho e blandície pelo diretor geral dos índios? O mesmo afirmou em outro documento que durante sua visita aos aldeamentos coroados levava uma "porção de miçangas e outras miudezas com que brindei os selvagens", pois "na verdade tais presentes muito servem para os contentar e atrair". Além dos presentes que levava ao visitar os 'selvagens', trazia consigo "o esquadrão da cavalaria" para que "me seja prestada uma pequena escolta " 117 . O diretor temia os índios, parecia considerá-los como uma ameaça à sua integridade física. Utilizava os serviços de uma escolta para se proteger, mas não despendia maiores recursos para presenteá-los, contentando-os com o que ele considerava ser miudezas. Para o casal de 'bugres', no entanto, foram empregados tratamentos bastante diferenciados, haja vista a quantidade e o valor dos objetos sortidos com que foram brindados. Eles iam desde tecidos e peças de roupas até itens importados, como um chapéu oriundo da cidade de Braga, em Portugal, e um xale francês. Nesse contexto onde era freqüente a preocupação com a nudez dos coroados, é interessante pensar no tipo de roupa que este casal teria recebido. Além disso, em 1847, quando o diretor geral dos índios visitou aldeamentos de Nonoai e Guarita foi gasto aproximadamente o dobro da quantia gasta apenas com um casal de 'bugres' ${ }^{118}$. O trânsito entre a região de Passo Fundo e Rio Pardo, e por conseguinte, entre os aldeamentos

${ }^{117}$ AHRS. Fundo Indígenas. Diretoria de Geral dos Índios. Aldeia de São Nicolau. Correspondência ativa de José Joaquim de Andrade Neves, maço 2, 1848. Rio Pardo, 06 de outubro de 1848. Os quatro últimos trechos foram retirados deste documento.

118 IDEM. Com o casal de coroados foram gastos aproximadamente $32 \$ 000$ réis e com a visita aos aldeamentos cerca de $70 \$ 000$ réis. 
de São Nicolau, Nonoai e Guarita era, realmente, intenso. A preocupação da Câmara de Rio Pardo com a estrada que comunicava os municípios aparece na documentação analisada ${ }^{119}$ :

a picada do Botucaraí que comunica este município com os do Passo Fundo e Cruz Alta de cima da serra, está quase intransitável parecendo que com a chegada da próxima estação invernosa ficará cortado o trânsito publico, por tal motivo, esta Câmara pede (...) a compostura da referida picada.

Nota-se que os contatos que índios guaranis mantiveram foram diversos. As relações sociais estabelecidas por eles podem ter sido percebidas como experiências de mestiçagem, transformando continuamente o processo de construção de suas identidades. A própria mobilidade espacial - vista como característica dos costumes culturais dos guaranis - sofreu mudanças em virtude das doenças, das políticas indigenistas e indígenas. As terras da serra do Botucaraí ${ }^{120}$, por exemplo, situadas a noroeste do Rio Grande do Sul, já eram freqüentadas e utilizadas por guaranis desde o começo do século XVIII para o cultivo da erva-mate. Alguns guaranis eram, inclusive, chamados de índios ervateiros. No começo do século XIX, a abertura de uma picada nessa serra facilitou a comunicação entre Rio Pardo e a região do planalto rio-grandense, assim como favoreceu o comércio da vila com a região das missões, ao encurtar o caminho de tropeiros e "afastar" os coroados da encosta da serra. Saindo de Rio Pardo em direção à região serrana, Avé-Lallemant percorreu essa estrada ao longo da qual havia plantações e novas picadas da colônia de Santa Cruz, fundada em virtude da chegada de imigrantes alemães na região, em contraste com as picadas mais antigas do vale do Rio Pardinho. A estrada ${ }^{121}$ :

119 AHMRP. Fundo Câmara, Série Correspondência. Livro de Correspondências N ${ }^{\circ} 3$, Paço da Câmara Municipal de Rio Pardo, 23 de dezembro de 1865.

120 "Essas montanhas são apenas a continuação e quase a extremidade de uma grande cadeia extensa, que segue a costa do Brasil. Aqui [na estância da Boca do Monte] recebe o nome de serra de São Xavier, oito léguas mais acima, o de serra de São Martinho e, pouco mais ainda, chama-se serra de Botucaraí”. SAINTHILAIRE, Auguste. Op. Cit. 2002, p. 393.

${ }^{121}$ AVÉ-LALLEMANT, Robert. Op. Cit. 1980, p. 178. 
vem de Jacuí do Rio Pardo e é a principal dali para o norte. Através de densas brenhas vai até o lugarejo de Nossa Senhora da Soledade do Passo Fundo, onde corta o Uruguai e penetra para o interior da província do Paraná e segue para São Paulo, num percurso de centenas de milhas.

Índios guaranis foram fotografados na região, no município de Soledade ${ }^{122}$. Estavam bem trajados, usavam botas e chapéus, ao contrário dos guaranis que habitavam há tempos atrás as aldeias do Rincão da Boca do Monte descritos por Saint-Hilaire. Na mesma região da serra do Botucaraí houve índios mal vestidos e outros que traziam em suas vestes sinais de distinção social. À sua frente, uma cuia de chimarrão que parece ser de metal. A cuia costumava ser feita de porongos e era o recipiente no qual consumiam a infusão da erva-mate, um costume ritual e tradicional dos guaranis. As atividades econômicas, como o comércio da erva-mate, privilégio exclusivo antes concedido aos guaranis de São Nicolau do Rio Pardo, pode ser uma das razões para que os índios fotografados em Soledade se apresentassem daquela maneira.

\footnotetext{
${ }^{122}$ O aldeamento guarani de Lagoão, no município de Soledade, foi extinto em 1918. KLIEMANN, Luiza H.
} Schmitz. RS: terra e poder - história da questão agrária. Porto Alegre: Mercado Aberto, 1986, p. 137. 


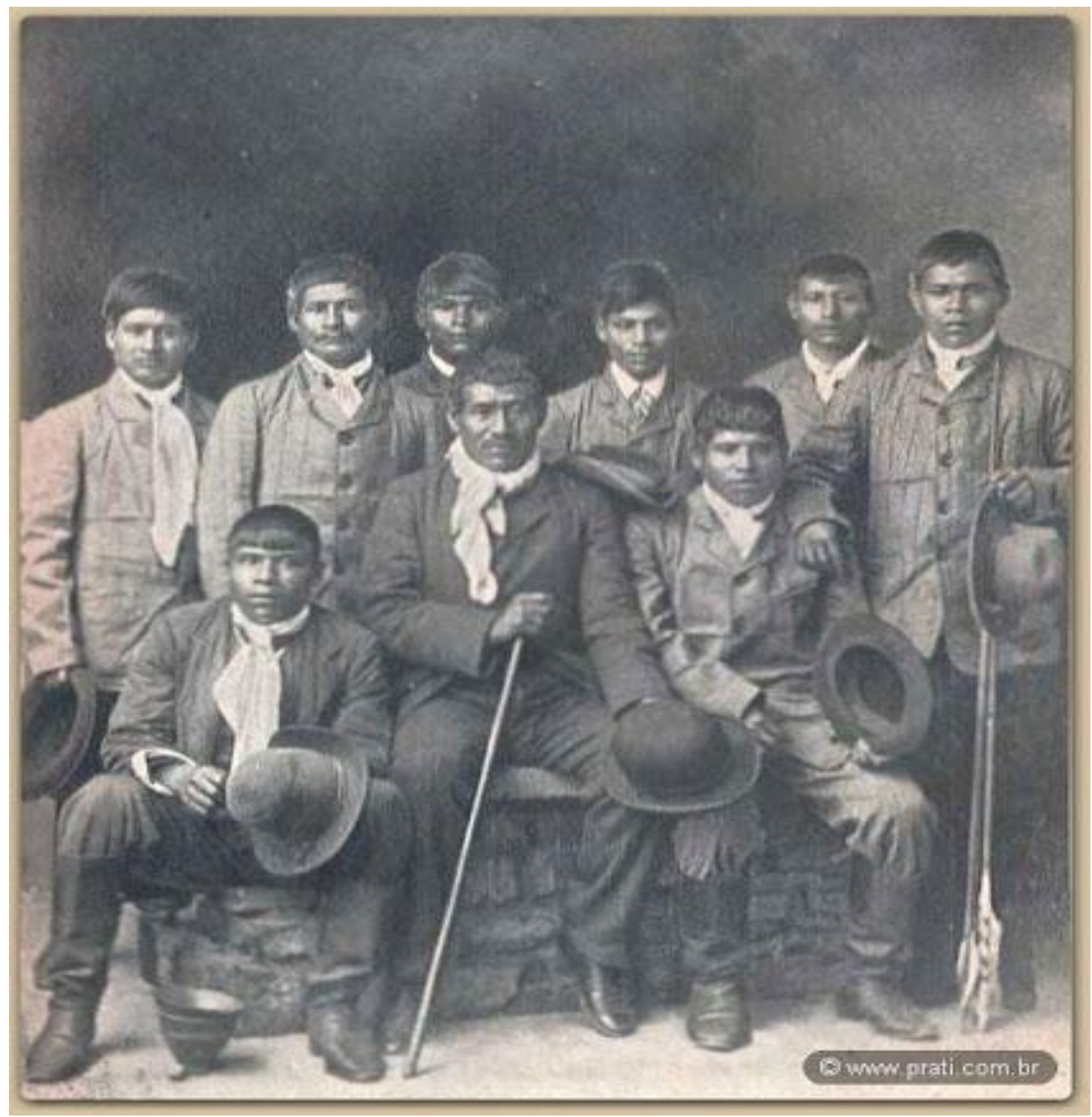

IMAGEM 5 - Índios Guaranis do aldeamento de Lagoão da Serrinha - Soledade ${ }^{123}$

Fonte: http://fotosantigas.prati.com.br/FotosAntigas/Diversos/indios/index.htm

Os índios guaranis não foram sempre os mesmos, nem sempre ficaram confinados ao espaço do aldeamento e receberam o mesmo tratamento. Os coroados com quem mantiveram contato também não. Suas condições de vida, códigos culturais e sociais variaram de um lugar para outro, de uma situação para outra. Mudavam também de acordo

\footnotetext{
${ }^{123}$ Site acessado em 02/11/2010. Acredita-se que a foto seja da primeira década do século XX.
} 
com o tempo e com os distintos acontecimentos que moldaram suas histórias. Se pouco sobre a história dos índios guaranis no Continente e na Província de São Pedro foi atribuída ao seu protagonismo, muito ainda permanece invisibilizado. Novas interpretações podem ser dadas a essas histórias, conferindo novos sentidos e significados aos atos indígenas ao longo de séculos de contatos. Eles estiveram ligados a doenças, deslocamentos espaciais, circulação de pessoas e objetos, formando redes de sociabilidade bastante complexas. A longevidade do aldeamento de São Nicolau do Rio Pardo evidencia que as ações dos guaranis não foram invisíveis ao longo do século XIX, como se verá também nos capítulos seguintes. 


\title{
CAPÍTULO 3 - ENTRE TERRAS E TERRITÓRIOS: IDENTIDADES INDÍGENAS EM CONSTRUÇÃO
}

\section{1 - INTRODUÇÃO}

Rio Pardo 200 anos

Uma luz para a história do Rio Grande Índios, esses desconhecidos.

\begin{abstract}
"Imagine quantas histórias um ser humano poderia contar se chegasse a dois séculos de vida. (...) Agora imagine a trajetória bicentenária de uma região inteira, que serviu de berço para inúmeras vidas, de diferentes etnias: índios, negros, espanhóis, portugueses, mestiços e outros. Todos eles, em diferentes períodos, querendo dominar o mesmo pedaço de chão. Um pedaço de chão que motivou diversas lutas, acordos e desacordos e que provocou relevantes transformações".
\end{abstract}

Dizeres da capa e do primeiro fascículo comemorativo dos 200 anos de Rio Pardo, Jornal Gazeta do Sul, 2008

No ano de 2009 a cidade de Rio Pardo comemorou 200 anos. As histórias que se passaram naquele território remontam a séculos antes de 1809 , quando foi elevada à condição de vila. Em virtude do bicentenário da cidade, o jornal Gazeta do Sul lançou edições comemorativas em parceria com a Universidade de Santa Cruz (UNISC) e com a Prefeitura da cidade. Foram treze fascículos contando e relembrando um pouco mais sobre a história de Rio Pardo e da região. O primeiro deles foi editado em outubro de 2008 e trouxe na capa a foto de uma criança e a seguinte frase: “Índios, esses desconhecidos". Nas 
páginas seguintes há informações e explicações sobre aspectos da formação histórica do município e sobre diferentes sujeitos e 'etnias' que ali viveram. As histórias dos guaranis não foram esquecidas ou deixadas de lado. Entretanto, os dizeres da capa não deixam dúvidas: ainda se sabe pouco sobre elas. A questão que move este capítulo é oferecer uma contribuição para que se saiba mais sobre a história social dos índios guaranis que estiveram na aldeia de São Nicolau do Rio Pardo no século XIX.

\section{2 - A ERVA-MATE}

Em 1823, mesmo ano do falecimento de João Pasqual Arazuc, o índio Miguel Guaraci saiu da aldeia de São Nicolau, onde era capitão, para ir à Rio Pardo encaminhar à presidência da província um documento no qual manifestava a preocupação dos índios guaranis com o futuro de suas terras e atividades comerciais e agrícolas. Ele solicitou através de um requerimento, que o privilégio da extração da erva-mate fosse mantido ${ }^{124}$. Ao alegar que o privilégio havia sido concedido há mais de cinqüenta anos por ordem superior do governador que atuava naquela época, José Marcelino de Figueiredo, Miguel demonstrou que os índios pensavam sobre o futuro e conheciam sobre seu passado. O governador havia se preocupado com a fuga dos índios e índias e era consciente dos fluxos e dos paradeiros deles. Tentou reunir os índios dispersos de Rio Pardo no aldeamento de São Nicolau. O privilégio concedido por ele garantia aos índios de São Nicolau do Rio Pardo o monopólio do plantio, colheita e comercialização da erva-mate. Quando o despacho dado pelo governador era infringido por aqueles que, nas palavras de Miguel, "não pertencem à sua classe" a erva-mate era apreendida. De acordo com ele, o privilégio outrora concedido era necessário para a manutenção das despesas dos índios. A menção de pertencimento a uma 'classe' que era entendida como 'sua' por parte do capitão da aldeia é interessante, visto que ele estava acompanhado por 'lavradores', de acordo com o título do

\footnotetext{
${ }^{124}$ Biblioteca Nacional do Rio de Janeiro, $I I-35,36,1$ n. 7. Guaraci, Miguel e outros. Pedem, o capitão-mor e outros lavradores, da aldeia de São Nicolau, na vila do Rio Pardo (RS), seja respeitada a concessão recebida há cinqüenta anos, do privilégio da plantação e preparo da erva-mate. Aldeia de São Nicolau, 1823. Agradeço a Elisa Garcia por ter cedido a mim a transcrição deste documento.
} 
requerimento. As relações de produção das quais os índios participavam e o tipo de trabalho que realizavam foi levado em conta quando se organizaram para fazer o requerimento. O cultivo e o comércio da erva-mate foram atividades de destacada importância econômica na Província. É importante levar em conta que a erva-mate era um produto que ${ }^{125}$

en un momento determinado de la vida de la sociedad indígena era consumido casi exclusivamente con fines ceremoniales y religiosos y que debia estar, por lo tanto, rodeado de un cierto halo prestigioso, al cortarse muchos de los primitivos lazos culturales que limitaban su utilizacion ritual, esta medicina mágica expande rapidamente su consumo en amplios sectores indigenas e inmediatamente mestizos.

Durante os séculos XVIII e XIX, o consumo da erva-mate se estendeu por praticamente todo o território da Província e o costume indígena se tornou um hábito cultural entre os demais habitantes. Auguste Saint-Hilaire, mencionou o consumo da bebida em várias passagens do seu diário de viagem, dizendo que ele mesmo havia se acostumado a ela ${ }^{126}$ :

A primeira vez que provei tal bebida, achei-a muito sem graça, mas cedo me acostumei a ela e, atualmente, tomo vários mates seguidamente com prazer, até mesmo sem açúcar. Acho no mate um ligeiro perfume misturado de amargor, que não é desagradável. Muito se tem elogiado essa bebida; dizem que é diurética, combate dores de cabeça, descansa o viajor de suas fadigas; e, na realidade é provável que seu sabor amargo a torne estomacal e, por isso, talvez seja necessária numa região onde se come enorme quantidade de carne (...).

A erva-mate estava amplamente difundida entre aqueles que não eram índios guaranis. Mas a aura de prestígio e os laços culturais ligados aos seus costumes se transformaram. As ervas de melhor qualidade costumavam ser exportadas para Buenos Aires, onde membros da elite se diferenciavam dos demais consumidores através do

${ }^{125}$ GARAVAGLIA, Juan Carlos. Mercado interno e economia colonial. México: Editorial Grijaldo, S.A., 1983, p. 37.

${ }^{126}$ SAINT-HILAIRE, Auguste. Op. Cit. 2002, p. 136. 
material de que eram feitas suas bombas e cuias, entre eles o ouro e a prata ${ }^{127}$. Relações sociais que envolviam posições de prestígio e privilégio continuaram a fazer parte dos novos rituais de consumo da bebida e do processo de fabricação. De acordo com AvéLallemant, o lugar mais agitado da cidade de Rio Pardo era uma grande fábrica de mate da cidade, onde um engenho colocava em movimento ${ }^{128}$

46 pilões de ferro para a pulverização das folhas e pequenos ramos, o que é feito com muita velocidade, de modo que já de longe se ouve o ruído (...). Preparam-se por dia mais de 100 arrobas, prontamente vendidas em Buenos Aires.

Os índios de São Nicolau não pareciam estar tão afastados do que era tido como o progresso da região, afinal o monopólio do plantio, colheita e comércio da erva-mate foi um privilégio concedido a eles ainda no século XVIII e continuou sendo uma das principais atividades comerciais da região de Rio Pardo até a última década do século XIX ${ }^{129}$ :

A erva, a divina yerba mate dos espanhóis, a centelha divina de Prometeu, pois é chupada, quente, de uma cuia por meio de uma bomba, vem em couros de boi ou em cestas de bambu dos ervais e depois é ensacada em meios couros de boi bem recortados $e$ costurados, para cuja feitura é preciso especial habilidade.

Os índios usaram estratégias para garantir a exclusividade no trabalho com a mesma. De acordo com Miguel Guaraci, as terras na serra geral, onde guaranis cultivavam a ervamate, estavam todas sendo divididas em lotes dados ou vendidos a diversas pessoas. Os índios de São Nicolau do Rio Pardo sentiam na prática os efeitos da lei de 1822. Segundo a historiadora Luiza H. Schmitz Kliemann, "no século XIX, com a lei de 1822, extingue-se a doação de sesmarias no Brasil e intensifica-se, dessa forma, a posse desordenada e a

\footnotetext{
${ }^{127}$ GARAVAGLIA, Juan Carlos. Op. Cit. 1983, p. 37.

${ }^{128}$ AVÉ-LALLEMANT, Robert. Op. Cit. 1980, p. 167.

${ }^{129}$ IDEM, p. 167.
} 
aglutinação de terras por particulares" ${ }^{130}$. Miguel reivindicava o privilégio sobre a produção e o comércio da erva-mate e ao mesmo tempo requeria o controle e a posse sobre as terras do aldeamento. Tal controle se tornava possível através do acionamento dos diferenciais que garantiam a eles privilégios e direitos sobre as terras. As referências feitas por Miguel aos tempos pretéritos e o conhecimento que ele possuía sobre as experiências coletivas pelas quais o aldeamento havia passado o ajudaram a atuar na administração daquele território, contribuindo para que a aldeia permanecesse sendo um espaço utilizado por índios guaranis ao longo dos três primeiros quartéis dos oitocentos. Ressaltamos que, se São Nicolau do Rio Pardo foi um espaço eminentemente indígena no decorrer do século XIX, isso também se deu graças ao acionamento de uma identidade coletiva.

As vendas e as apropriações das terras e das propriedades tidas como patrimônio do aldeamento começaram a ocorrer, sobretudo, depois da segunda década do século XIX, conforme as fontes consultadas. Em 1823, Miguel também questionou se os demais nacionais poderiam utilizar as terras da serra, onde estavam suas plantações, para a finalidade de comercializar a erva-mate, já que o monopólio pertencia aos índios. Nesse período, grande parte das disputas pela posse dos territórios se dava entre os índios e os 'nacionais'.

Em 1825, os guaranis de São Nicolau do Rio Pardo ganharam terras onde havia plantações de erva-mate. Pelo que as fontes indicam, essas terras eram parte de um território maior de onde os guaranis já extraiam a erva. $\mathrm{O}$ requerimento das mesmas havia sido feito ainda na época em que o conde da Figueira governava a capitania (1818-1821). Mas entre 1834 e 1835, Elautério Rodrigues Lima requereu uma medição e demarcação do terreno dos ervais, "vindo ele ficar Sr. de todos eles, porque se lhe mediram três léguas de matos que abrangeram todos aqueles ervais e até o mesmo que se lhe havia comprado para essa aldeia em $1825^{\prime \prime 131}$. Havia a justificativa de que os cofres provinciais e mesmo os índios, não dispunham de recursos para pagar as despesas feitas com os engenheiros que

\footnotetext{
${ }^{130}$ KLIEMANN, Luiza H. Schmitz. RS: terra e poder - história da questão agrária. Porto Alegre: Mercado Aberto, 1986, p. 18.

131 AHRS. Fundo Indígenas. Diretoria Geral dos Índios. Correspondência ativa: José Joaquim de Andrade Neves, 1848, 24 de outubro de 1848.
} 
mediam os terrenos. A explicação do diretor geral dos índios revela aspectos que fizeram parte das negociações ${ }^{132}$ :

Eu na ocasião daquela medição me opus com alguns requerimentos por parte dos indios, por me terem nomeado seu procurador, paguei a João Rodrigues Palhares para requerer como solicitador, puseram-se embargos a medição antes de para ela partir o juiz, não se atendeu a nada e enfim este negócio para se realizar precisa muito dinheiro ou um braço que não vergue.

Após essa medição, os índios trabalharam nos ervais durante cerca de três anos sem que Elautério Rodrigues Lima se opusesse. Quando isso aconteceu, o vice-presidente da Província mandou proceder à reivindicação daqueles ervais por meios judiciais através da promotoria pública, "o que até hoje se não tem posto em prática como V. S. sabe, por falta de meios para semelhantes despesas, e por este motivo não se tem feito erva alguma" ${ }^{133}$. A medição das terras dos ervais não era a única dificuldade que os índios enfrentaram para manter as atividades de produção da erva-mate ${ }^{134}$ :

Falei com a viúva do Morais para me deixar este ano fazer alguma erva em seus matos, disse-me que sim, porém que eu lhe havia dar a metade da que se fizesse, o que não me convêm, e portanto vêem-se os naturais do Brasil, primários e senhores de tão grandes matas sem terras onde fabriquem uma arroba de erva-mate para seu consumo.

À medida que as terras dos ervais eram vendidas a particulares, a políticos e militares, como veremos adiante, as condições dos guaranis de São Nicolau do Rio Pardo ficavam mais difíceis. As tentativas de tomada da terra foram muitas e causaram confusões envolvendo a posse das mesmas pelos índios. Por outro lado, parecia haver outras maneiras

\footnotetext{
132 IDEM.

${ }^{133}$ IDEM.

${ }^{134}$ IDEM.
} 
de continuar nas atividades com a erva-mate, como nos dá indícios o relato do padre Ambros Schupp, escrito no ano de $1875^{135}$ :

Como acontece nas demais áreas de colonização alemã, também essa paróquia situa-se numa região de terreno fortemente ondulado. O rio Pardinho, um afluente do rio Pardo, corta-a de norte a sul em toda a sua extensão. É possível distinguir nitidamente duas zonas no que diz respeito ao clima e à cultura: uma no planalto e outra na planície. A zona baixa ou zona colonial é ocupada exclusivamente por agricultores alemães e a zona norte ou zona da serra é povoada por brasileiros, ocupando-se do cultivo de ervais (erva do Paraguai) e a fabricação da erva-mate. São conhecidos como ervateiros ou carijeiros, e o produto de seu trabalho é a erva-mate, sendo a barbaquá a variedade mais apreciada. Os tropeiros a transportam até a colônia no lombo de mulas e de lá é encaminhada para a comercialização.

O padre fez uso do clima e da geografia do terreno para estabelecer diferenças étnicas e nacionais entre pessoas com diferenças culturais. Este não pode ser considerado um comportamento atípico para a época. A experiência humana podia ser compreendida a partir de escalas evolucionistas ligadas a uma seleção que a própria natureza era capaz de fazer dos seres humanos, daí a relação entre clima e cultura. Uma diferença entre brasileiros/ervateiros/carijeiros e alemães foi estabelecida tendo como parâmetro o produto da atividade agrícola à qual se dedicavam naquele território. O uso do termo carijeiros é interessante quando levamos em conta outros usos já feitos do etnônimo carijó no $\operatorname{passado}^{136}$ :

Originalmente, desde meados do século XVI, o etnônimo carijó referia-se aos Guarani em geral, objeto principal tanto dos paulistas apresadores de escravos, quanto dos missionários franciscanos e jesuítas da América espanhola e portuguesa. Até 1640, a sociedade paulista foi marcada profundamente pela chegada de um fluxo constante de cativos guarani, provenientes sobretudo do sertão dos Patos e do Guairá.

${ }^{135}$ SCHUPP, Pe. Ambros. A missão dos jesuítas alemães no Rio Grande do Sul. São Leopoldo: Editora Unisinos, 2004 [1912], p. 106. O padre Schupp veio para o Brasil em 1874.

${ }^{136}$ MONTEIRO, John Manuel. Op. Cit. 1994, p. 165 
Segundo John Manuel Monteiro, a introdução do termo carijó no século XVI pode estar relacionada com estratégias de padronização de populações a partir do modelo do cativo guarani. Tais padronizações foram vinculadas ao uso de uma categoria étnica, refletem táticas políticas e "um processo histórico envolvendo a transformação de índios em escravos" 137 . É claro que o contexto onde o padre Schupp fez uso do termo carijeiros era bem diferente, entretanto, pode ser que as terminologias de carijeiros e ervateiros também apontassem para a reconstituição de uma identidade indígena. Este contexto em que os índios foram vistos como "mestiços" ou "misturados", coincide com o momento em que a sua extinção e a de seus aldeamentos era tomada como inevitável e imprescindível para que pudesse haver o loteamento das terras para outros grupos sociais ${ }^{138}$ :

Na zona baixa reinam o trabalho e o bem-estar e o empenho em promover a cultura. Em toda a parte encontram-se moradias bem construídas e bem instaladas. Na zona alta predomina uma pobreza despreocupada. As pessoas vivem em choupanas miseráveis, chamadas ranchos, apesar de dispor em abundância de material para a construção de moradias melhores. Comem quando têm alguma coisa e sabem passar fome quando de nada dispõem. Divertem-se com as carreiras e os fandangos. Em sociedade circulam a cuia e a bomba com chimarrão fervente. Não sentem necessidades religiosas, suas capelas não passam de choupanas de tábuas, através das quais assobia o vento.

A presença de guaranis no vale do Rio Pardo e o processo histórico de construção das suas identidades estiveram ligados à produção de erva-mate e à presença dos colonos alemães. Entretanto, os colonos não foram os únicos com quem guaranis se relacionaram. A zona alta a qual o padre se refere é a região da serra do Botucaraí. A picada de mesmo nome ligava a cidade de Rio Pardo à região de Passo Fundo, onde ficava os aldeamentos de índios coroados chamados Nonoai e Guarita. Diversos tipos de contato aconteciam entre esses aldeamentos, como já vimos. Em 1850, o diretor dos mesmos escreveu o seguinte em resposta a uma proposta do presidente da Província $^{139}$ :

\footnotetext{
${ }^{137}$ IDEM, p. 166.

${ }^{138}$ IDEM, p. 107.

139 AHRS. Fundo Indígenas. Diretoria Geral dos Índios. Correspondência ativa: José Joaquim de Andrade Neves, 01 de janeiro de 1850 .
} 
Como tenho estado ali conheço as vantagens que se pode obter de sua proposta e ser a mais adequada para o fim que se pretende, não é a companhia de pedestres, nem a de polícia que se imporão respeito aos índios, e ao mesmo tempo os ajudem e ensinem a trabalhar na lavoura e fábrica de erva-mate.

O presidente havia proposto que outros, que não seria a companhia de pedestres nem a de polícia, ajudassem e ensinassem aos índios do aldeamento da Guarita como trabalhar com a erva-mate. Eles aprenderiam a cultivá-la justamente no momento em que as disputas de terra em São Nicolau do Rio Pardo foram acirradas ${ }^{140}$ e os índios praticamente haviam perdido os ervais. Quem os ensinaria? Pode ser que fossem os guaranis, mestres na arte desse cultivo. Houve contato e trocas de práticas e saberes entre os índios de Guarita, Nonoai e São Nicolau do Rio Pardo. Ponto importante de ser observado na formação das identidades étnicas nesse período é que grande parte das ações dos índios guaranis indicam que a reivindicação de seus direitos tenha sido feita com base no acionamento de uma identidade coletiva, a de índios aldeados ${ }^{141}$. Os usos que fizeram dos espaços dos aldeamentos podem ter sido muito variados. Nesse caso específico analisado, a própria condição de 'índio aldeado' pode ter se apresentado como uma possibilidade de continuar com as atividades ligadas ao cultivo e à produção da erva-mate. Tal condição pode ter sido acionada em momentos críticos como algo representativo de sua própria identidade, já que dela prescindiam para serem diferenciados dos demais 'nacionais' e estrangeiros. O que quero sugerir é que num momento em que suas terras estavam sendo usurpadas e, por vários motivos, os índios estavam sendo impedidos de prosseguir nas atividades com a erva-mate, a condição de aldeados pode ter representado uma alternativa viável, mesmo que implicasse na ida provisória de guaranis para um aldeamento de coroados. Esses contatos não eram exatamente o que se pode chamar de uma novidade para os índios ${ }^{142}$ :

\footnotetext{
${ }^{140}$ Como veremos algumas páginas adiante.

${ }^{141}$ ALMEIDA, Maria Regina Celestino. Op. Cit. 2005, p. 237.

142 BAPTISTA, Jean. "A visibilidade étnica nos registros coloniais: missões guaranis ou missões indígenas?" in BOEIRA, Nelson; GOLIN, Tau (coord.). KERN, Arno; SANTOS, M. Cristina; GOLIN, Tau (dir). Povos Indígenas. Passo Fundo, Méritos, 2009, Vol. 5. (Coleção história geral do Rio Grande do Sul), p. 226.
} 
Após uma sistematização minuciosa da documentação jesuítica, não restam dúvidas de que os povoados missionais foram compostos por uma diversidade de grupos étnicos significativos na geração, desenvolvimento e complexidade daquela experiência. Impõe-se, assim, um importante princípio de abordagem documental: o reconhecimento da diversidade como característica fundamental daquele processo em conjunto à avaliação de significativas transformações identitárias oriundas do contexto.

É comum encontrar em vários tipos de fontes históricas, que se estendem desde o século XV até parte do XX, juízos de valor que imputam aos índios comportamentos ligados à falta de provisão e preocupação com futuro. Trata-se de uma longa e arraigada 'tradição cultural' que, no entanto, vem sendo modificada através de uma série de informações que as fontes trazem a respeito de sua história. Ações dos índios de São Nicolau do Rio Pardo geraram registros que não deixam dúvidas sobre o fato de que eles se preocuparam com a manutenção de seus territórios, com a continuidade de suas atividades comerciais e com a garantia de seus direitos históricos.

\section{3 - A IGREJA DE SÃO NICOLAU DO RIO PARDO}

Em meio aos argumentos de ordem jurídica e administrativa que Miguel Guaraci apresentou, houve um que certamente respaldou o direito de monopólio nas atividades com a erva-mate, concedido aos índios de São Nicolau do Rio Pardo na década de 1770. Segundo ele, além da necessidade de sustentar a aldeia, existia também a necessidade de reparar a sua igreja. As autoridades políticas e religiosas da época viam com bons olhos o fato de serem índios catequizados, considerados 'cristãos' e 'civilizados'. Como lembra Almir Diniz Carvalho Júnior para o contexto da Amazônia portuguesa, "índios cristãos não estavam alheios às conseqüências positivas das mercês concedidas pelo monarca" ${ }^{143}$, assim como no caso analisado, guaranis notavam que sua religiosidade lhes garantia tratamentos diferenciados dos demais indígenas da Província. Atentos a isso, eles continuaram a manter sua igreja reformada ao longo dos séculos XVIII e XIX, apesar das dificuldades

${ }^{143}$ CARVALHO, Jr. Almir Diniz de. Op.Cit. 2005, p. 219. 
encontradas: “Os que estão de efetiva residência são na maior parte velhos e inválidos (...). A sua pequena capela, a pouco restaurada, reclama por um sacerdote" ${ }^{144}$.

A igreja do aldeamento simbolizava a religiosidade cristã dos índios e lhes proporcionava certo prestígio junto às autoridades políticas. É verdade que tal prestígio remonta à época colonial. O vice-rei do Brasil, o marquês do Lavradio, chegou a conceder em 1772 um "sino para a nova povoação de São Nicolau do Rio Pardo e V. M. persuadirá os novos povoadores, façam as suas igrejas, dando-lhes algum pequeno adjutório, que vem a ser a telha para as cobrirem" ${ }^{145}$. O capitão do aldeamento demonstrou que sabia usar os códigos da sociedade envolvente em favor dos interesses de índios guaranis. Miguel usouos em benefício próprio e dos seus, e contra aqueles que ameaçavam sua exclusividade naquela atividade. Ao perceber o loteamento das terras indígenas para colonos e 'nacionais', ele agiu no sentido de reaver e manter os direitos coletivos. A religiosidade cristã está presente nos escritos sobre a morte do curumim João Pascual e no requerimento encaminhado pelo capitão de São Nicolau do Rio Pardo. Ambos apresentam preocupações com a posteridade e permitem saber mais sobre as estratégias e as vivências indígenas ${ }^{146}$ :

Depois da primitiva capela de São Nicolau, erigiram os povos outra também coberta de capim com o mesmo orago e frente ao Norte, onde é hoje a praça principal, cujos alicerces há pouco tempo mandou a Câmara Municipal arrancar para com a pedra calçar a rua que vai ao lugar do desembarque (...).

Houve ocasiões em que as benfeitorias feitas pelos guaranis na sua igreja ficaram comprometidas pelas ações das autoridades políticas de Rio Pardo, como esta em que a Câmara mandou retirar material dela para calçar uma rua. O episódio envolvia outras questões como a obtenção de recursos financeiros para o conserto da igreja mediante a venda de pedras e erva-mate. É estranho que a Câmara de Rio Pardo tenha pretendido

${ }^{144}$ AHPA. Relatório do Vice-Presidente da Província de São Pedro do Rio Grande do Sul, Joaquim Antão Fernandes Leão, na abertura da Assembléia Legislativa Provincial, 1859.

145 ANRJ. Fundo: Marquês do Lavradio, microfilme 024-97, RD 2.106v. Carta para Antônio da Veiga Andrade. Rio de Janeiro, 29 de abril de 1772.

${ }^{146}$ INSTITUTO HISTÓRICO E GEOGRÁFICO DO RIO GRANDE DO SUL. DIAS LOPES, Vicente Zeferino. "Comentário Eclesiástico do Rio Grande de São Pedro do Sul desde 1737”. Cópia datilografada. Caixa D, no 10 . 
consertar a igreja angariando recursos a partir do seu desmanche. As negociações e as explicações contraditórias dadas em virtude do acerto parecem ser sintomáticas a respeito da improbidade na administração do aldeamento. A diretoria geral dos índios havia feito um empréstimo com a presidência da Província para as obras da igreja de São Nicolau do Rio Pardo e para a compra de rações de carne aos índios. Entretanto, não pôde saldar a dívida de "um conto, trezentos e sessenta mil réis por empréstimo para a compra de carros e bois e para rações dos índios da Aldeia de São Nicolau, com a cláusula de ser restituída logo que se vendesse a pedra e a erva mate que foi fabricada pelos ditos índios" ${ }^{147}$. Havia situações em que autoridades políticas aparentavam estimar os esforços dos índios. Em outras pareciam se aproveitar delas. Por outro lado, eles continuavam tentando manter sua igreja e até mesmo trataram de reconstruí-la em mais de uma ocasião ${ }^{148}$ :

Posteriormente os índios, de que existem ainda alguns descendentes, levantaram nova capela no lugar mais alto do aldeamento dedicada também a São Nicolau a quem consagraram grande doação.

Eles se mostravam cientes de que sua religiosidade lhes colocava numa posição de destaque. Demonstravam-na através do cuidado com a manutenção da igreja. Muitas vezes, seus bens foram usurpados por autoridades políticas, sob o pretexto de promover reformas e benfeitorias no aldeamento. Todavia, a intenção dos índios não parecia ser apenas uma estratégia usada para atrair a atenção dos políticos e religiosos, apesar dos resultados positivos. A religiosidade cristã parecia, de fato, fazer parte dos seus costumes culturais ${ }^{149}$ :

Nesta capela que foi destruída na revolução da Província, celebravam eles suas festas, principalmente a Semana Santa na qual o que representava a ressurreição de Cristo era designado pelo cacique, que fazia sempre recair a escolha no que mais pecados tinha cometido no ano antecedente e de quem era mais inimigo.

${ }^{147}$ AHRS. Fundo Indígenas. Diretoria Geral dos Índios. Correspondência ativa: José Joaquim de Andrade Neves, 1848, 24 de outubro de 1848.

148 INSTITUTO HISTÓRICO E GEOGRÁFICO DO RIO GRANDE DO SUL. DIAS LOPES, Vicente Zeferino. "Comentário Eclesiástico do Rio Grande de São Pedro do Sul desde 1737". Cópia datilografada. Caixa D, no 10, p. 68.

${ }^{149}$ IDEM, p. 68-69. 
A religiosidade guarani aparece misturada à religiosidade cristã. Não se sabe se a comemoração ocorria em outros lugares ou se era uma prática que acontecia apenas no aldeamento de São Nicolau do Rio Pardo. Mas a questão não é sobre a existência de um comportamento cultural que poderia ser considerado como uma prática constante entre os guaranis. Mesmo que fosse assim, tal prática não parece ter sido tomada pelos índios somente com o intuito de satisfazer à expectativa das autoridades provinciais. Os elementos e os motivos cristãos e não cristãos do ritual pareciam fazer parte de um costume religioso e cultural dos índios, por isso chamava a atenção. Provavelmente, eles modificaram e ritualizaram práticas tradicionais para que elas servissem a novos propósitos, assim como outros segmentos da sociedade envolvente fizeram com o consumo da erva-mate. É interessante observar a utilização de elementos que parecem ser antigos e tradicionais - a tomada de decisões por parte do cacique, no caso da cultura política indígena; ou a representação da ressurreição de Cristo, no caso da cultura religiosa 'ocidental' - para elaborar novas tradições, onde o inimigo do cacique representa Cristo e é punido pela autoridade indígena. $\mathrm{O}$ fato de a semana santa cristã ter sido celebrada através de rituais que, à primeira vista não possuem vínculos com seus 'costumes culturais', indica que podem ter dominado alguns símbolos que tornariam possível sua sobrevivência em meio às políticas assimilacionistas da época, afinal tratamentos diferenciados foram concedidos em situações em que sua religiosidade era valorizada. A mestiçagem entre práticas rituais e religiosas e inovações advindas da sociabilidade não era algo passível de acontecer somente em São Nicolau do Rio Pardo. Curt Nimuendajú Unkel, um alemão que esteve entre os apapocúva-guarani durante as duas primeiras décadas do século $\mathrm{XX}$, ao observar uma cerimônia de nominação entre os mesmos considerou que se tratava de ${ }^{150}$ :

uma ação mágica genuinamente americana, sem nenhuma intrusão de elementos estrangeiros. Segue-se a ela, todavia, outro procedimento cuja ordem é indubitavelmente cristã. $O$ motivo cristão que lhe serve de base está de tal forma recoberto de antigos temas indígenas, que sua introdução deve remontar a séculos, à época jesuítica.

\footnotetext{
${ }^{150}$ NIMUENDAJÚ, Curt Unkel. As lendas da criação e destruição do mundo como fundamentos da religião dos Apapocúva-Guarani. São Paulo: Hucitec/Edusp, 1987, p. 30.
} 
Para o caso dos índios de São Nicolau do Rio Pardo, as categorias identitárias e superpostas em que se classificariam suas tradições parecem se misturar com as experiências vividas por eles. A celebração simbolizava condições de coesão social, pressupunha criatividade e certa identificação comunitária, neste caso, étnica e política (guaranis aldeados). Podem ter sido usadas no estabelecimento ou na legitimação de identidades, já que 'as festas' eram realizadas na igreja do aldeamento, sendo este território reconhecido politicamente como um espaço indígena, assim como os ritos religiosos eram reconhecidos como o provável resultado de práticas mestiçadas. Isso interferia na identidade étnica atribuída a eles. E assim, pode ter contribuído para a socialização de idéias e padrões de comportamento e valores. Tratava-se de índios cristãos, e justamente por possuírem uma identidade étnica e outra religiosa gozavam de certos privilégios políticos. A posse do território da aldeia lhes era garantida pelo fato de serem índios, mas ela foi muitas vezes mantida pelo fato de serem cristãos.

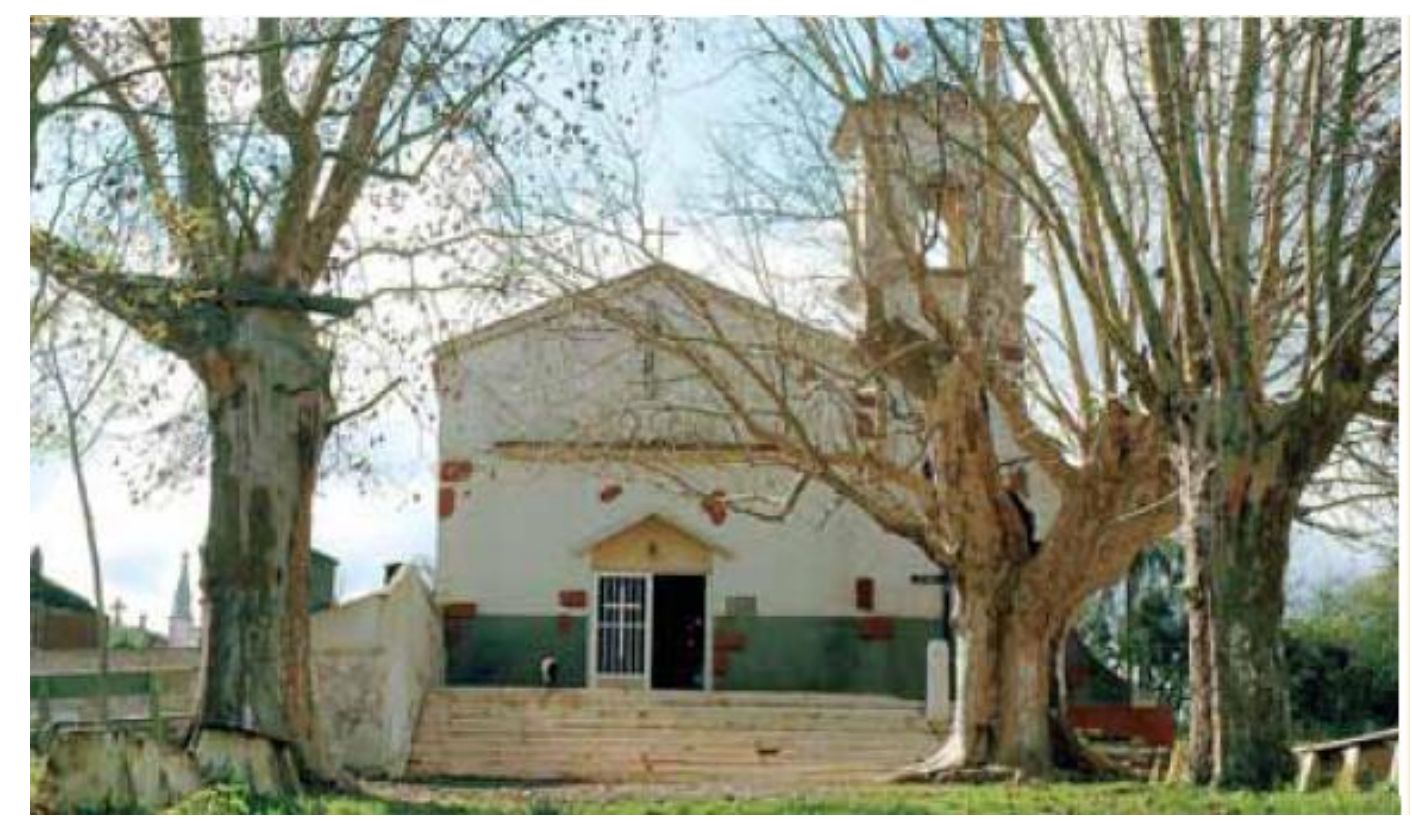

IMAGEM 7 - Atual igreja da aldeia de São Nicolau do Rio Pardo ${ }^{151}$.

Fonte: http://www.riopardo200anos.com.br/fasciculo.html, acessado em 5 de janeiro de 2009.

\footnotetext{
${ }^{151}$ A aldeia de São Nicolau ainda existe e preserva alguns vestígios dos tempos em que foi habitada por índios guaranis. Hoje é habitada por moradores da cidade de Rio Pardo. As festas em devoção a São Nicolau acontecem todos os anos, no mês de dezembro, na igreja da aldeia. Existe um cemitério na parte de trás do templo. Os nomes que atualmente se encontram nas lápides são de origem alemã, em sua grande maioria. A foto foi retirada do primeiro fascículo comemorativo dos 200 anos de Rio Pardo, publicada pelo Jornal Gazeta do Sul, em outubro de 2008.
} 


\section{4 - DISPUTAS POR TERRAS E DIREITOS TERRITORIAIS}

Se por um lado os índios podiam ser vistos como convertidos e aliados através da religião, por outro podiam ser vistos como adversários políticos na disputa pela posse da terra. O mapa estatístico das conciliações propostas pelo Juizado de Paz de Rio Pardo entre os anos de 1834 e 1835 mostra uma situação que envolve os índios em conflitos por terras e benfeitorias. Um requerimento foi feito através dos devidos meios jurídicos por um índio de São Nicolau do Rio Pardo, cujo nome não é citado na fonte. Ele reivindicava "o pagamento de [ilegível] um terreno e casas aos guaranis da aldeia de São Nicolau" ${ }^{152}$ no distrito do Couto, que pertencia a Rio Pardo e ficava a cerca de $8 \mathrm{~km}$ do centro da cidade. A reivindicação foi aceita pelo Juizado de Paz e a conciliação foi proposta através das vias legais. Trata-se o documento de um levantamento estatístico, em que não encontramos maiores detalhes sobre os requerentes e os requeridos, ou sobre o desenrolar do processo. Mesmo assim os dados quantitativos encontrados nesta fonte são bastante úteis, pois mostram que das dez proposições encaminhadas pelo Juizado de Rio Pardo durante o período de dois anos, uma foi feita por um índio do aldeamento, e outras três foram "para a divisa de terrenos e matos". Isso nos indica que a diáspora espacial e temporal dos guaranis também se deu em função de conflitos sociais gerados nas disputas por posses de terra, e de acordo com as demandas políticas dos índios em relação à luta pela manutenção de seus direitos territoriais. Demonstra que alguns deles sabiam como acionar as disposições presentes na legislação e nas políticas indigenistas, que haviam levado em conta a distinção étnica e os precedentes históricos na elaboração das mesmas. No ano de 1845, com a instituição do Regulamento das Missões, as Assembléias Legislativas Provinciais gozaram de um relativo grau de autonomia. As medidas tomadas em função desse regulamento, da lei de Terras de 1850 e do regulamento de 1854, foram chamadas por Luiza Schmitz Kleimann de "descompasso entre o legal e o real" ${ }^{153}$ :

\footnotetext{
${ }^{152}$ AHRS. Fundo Estatística. Livro de estatística judicial dos juizados de paz (1830-1844). Mapa estatístico das conciliações propostas pelos juizados de paz de Rio Pardo. Maço 1, 1833.

${ }^{153}$ KLIEMANN, Luiza H. Schmitz. Op. Cit., 1986, p. 21.
} 
A lei de Terras de 1850 e o respectivo regulamento de 1854 estabelecem que a aquisição de terras devolutas, a partir de então, seria feita através da compra, em hasta pública, reservando-se as dez léguas de fronteira, bem como as terras para colonização indígena, fundação de povoados, abertura de estradas, construção naval e de estabelecimentos públicos. Consideravam-se terras devolutas, as não cultivadas em poder do Estado ou as posses não legitimadas.

Nas terras consideradas devolutas havia grupos indígenas e algumas províncias optaram por 'desinfetar' os sertões daqueles que eram considerados dissidentes do projeto de formação da nação. Os índios considerados importantes para o projeto 'civilizacional' eram os aldeados. Eles representavam um contingente populacional que poderia vir a constituir força de trabalho, se assimilar ou misturar em meio aos demais trabalhadores. Tratava-se de uma espécie de distinção feita pelo estado nacional entre índios selvagens e índios aldeados e, nesse sentido, a inserção dos indígenas em aldeamentos permitia que alguns deles conseguissem manter uma identidade étnica baseada nessa condição diferenciada. $\mathrm{O}$ fato de eles serem catequizados e assistidos por padres missionários lhes proporcionava oportunidades de viver de forma bem menos violenta do que aqueles que viviam fora dos aldeamentos. Por certo que os territórios dos aldeamentos não estavam livres de violências, inclusive violências morais e simbólicas, mas às vezes ofereciam melhores condições de sobrevivência do que as matas. A tônica do projeto indigenista até meados do século XIX era referendada pelas diretrizes assimilacionistas do projeto pombalino. Mas havia aspectos da política indigenista do Oitocentos que eram distintas das disposições presentes no Diretório dos Índios. Enquanto este previa a assimilação e a integração dos indígenas através da persuasão e do convencimento, aquela abria precedentes legais para uma série de atrocidades contra os índios. Vale lembrar que havia expedições organizadas para matar índios 'selvagens' e ou não-aldeados. Através de processos que Manuela Carneiro da Cunha chamou de "políticas de intrusamento" e "políticas de concentração" 154 , aos índios eram oferecidas poucas e já conhecidas opções: a cruz ou a espada, ou seja, a conversão através da catequese nos aldeamentos ou o extermínio. Essa frase pode parecer um pouco forte, mas de fato houve em todo o Brasil, durante o século XIX, o que poderíamos entender como políticas públicas de extermínio

\footnotetext{
${ }^{154}$ CUNHA, Manuela Carneiro da. "Política Indigenista no século XIX”, in História dos índios no Brasil. São Paulo: Companhia das Letras, 1992, p. 142-143.
} 
dos índios tidos como 'selvagens' ou 'não-civilizados'. Quando 'as partidas ou correrias de índios' não eram feitas por particulares, as chamadas Companhias de Pedestres eram encarregadas e pagas pelo governo provincial para deixar as matas e os colonos livres dos índios. Na Província de São Pedro não era diferente. Pouco tempo depois do estabelecimento da lei de Terras, o vice-presidente da Província relatava ${ }^{155}$ :

\begin{abstract}
O sistema da força, e o da persuasão que se tem empregado separadamente para tirar das matas os nossos indígenas, tem sidos ambos improfícuos. Até aqui nos temos limitado a: $1^{o}$ - a atrair os índios por meio de algumas roupas, e ferramentas distribuídas nas aldeias de Nonohay e Guarita, e a conservá-los ali pelos esforços dos padres jesuítas; de catequisação propriamente dita pouco se tem feito, sem dúvida porque aqueles padres ignoram a lingua, em que deveriam dirigir aos índios as palavras de conversão; $2^{\circ}$ - a bater os índios, perseguí-los, e matá-los, quando eles têm feito alguma agressão, e a colocar guardas por algum tempo nos lugares que eles têm agredido. Pela simples enunciação se vê que esses dois sistemas são incompletos, e a experiência os têm condenado. Os índios recebem as roupas, e as ferramentas, $e$ voltam às matas; batidos e perseguidos depois da agressão, reaparecem mais hostis em outros lugares, não sendo possível colocar guardas em todos aqueles por onde fazem seus assaltos.
\end{abstract}

Apesar das informações trazidas pelo relatório dos presidentes da Província, houve outros caminhos pelos quais políticos, religiosos e índios se relacionaram com a ‘cruz' e a 'espada'. Em 1850, o diretor geral dos índios uniu no mesmo documento dois assuntos cuja ligação com atos de violência ficou implícita: a retirada do padre e da companhia de pedestres do aldeamento de Nonoai e a necessidade de se formar uma polícia para São Nicolau do Rio Pardo. Com a saída do padre e a ausência da companhia de pedestres os índios de Nonoai estavam voltando às matas por falta de mantimentos. O padre Bernardo Parés, que cumpria a função de diretor interino, abandonara o cargo. Quanto a São Nicolau do Rio Pardo ${ }^{156}$ :

\footnotetext{
155 AHPA. Relatório do Vice-Presidente da Província de São Pedro do Rio Grande do Sul, Luiz Alves Leite de Oliveira Bello, na abertura da Assembléia Legislativa Provincial, 01 de outubro de 1852.

156 AHRS. Fundo Indígenas. Diretoria Geral dos Índios. Correspondência ativa: José Joaquim de Andrade Neves, 11 de março de 1850 .
} 
Tendo requisitado da presidência uma polícia para a aldeia de São Nicolau o Exmo. General Andréa nunca quis [atender] a essa minha requisição, pelo que tenho organizado uma dos índios e para os ensinar é preciso que V. Ex. me mande remeter dez espadas, dez pistolas, com cartucheiros e com cartuchos embalados para as mesmas, ainda que sejam já servidas.

Alguns meses mais tarde solicitou-se um destacamento policial para a aldeia de Nonoai. O motivo era que antes da dissolução da companhia de pedestres e da saída do padre, "os bugres respeitavam aos missionários e se uniam muito com os soldados, logo que estes foram dispersos, muitos bugres se embrenharam nos bosques e vivem em contínua rixa"157. A fuga dos índios costumava ter como medida o uso da violência através da atuação da companhia de pedestres e da polícia. Ambos eram encarregados de conduzir os índios fugidos de volta ao aldeamento. Entretanto, em algumas ocasiões os índios aldeados se uniam aos soldados das companhias e polícias. Em outras, eram os próprios índios quem compunham o corpo policial. Nesse sentido, é importante ressaltar que as situações constantes de conflitos e violências não implicam a inexistência de negociações; ao contrário, o aparente estranhamento que sugere a 'união' de soldados e indígenas é uma pista sobre isso e, nesse sentido, as palavras de Gerald Sider $^{158}$ são apropriadas:

The point here is not to dismiss violence as secondary, as do many contemporary theorists of 'hegemony' but, to the contrary, to embed it at the core of processes that form and transform culture, and so to build strategies for contesting domination.

Em alguns casos, os índios tiraram proveito de sua condição étnica através de meios jurídicos e legais. Mas isso não impediu que atos violentos e tentativas de apropriação de territórios indígenas cessassem. No ano de 1849, o presidente e os vereadores da Câmara Municipal de Rio Pardo encaminharam um ofício a algumas pessoas exigindo informações sobre as terras de São Nicolau do Rio Pardo. Através dele podemos acompanhar parte das

\footnotetext{
157 AHRS. Fundo Indígenas. Diretoria Geral dos Índios. Correspondência ativa: José Joaquim de Andrade Neves, 28 de dezembro de 1850.

158 SIDER, Gerald. "Identity as History, Ethnohistory, Ethnogenesis and Ethnocide in the Southeastern United States”. Identities Global Studies in Culture and Power. New Hampshire, vol. 1. 1994. p. 109.
} 
implicações decorrentes da improbidade administrativa no aldeamento e da usurpação das terras e benfeitorias dos índios ${ }^{159}$ :

Tendo pelo juízo dos feitos da Fazenda Nacional de se proceder a incorporação dos bens dos índios de Missões desta Província, dos próprios nacionais em conformidade do artigo 30 de 21 de outubro de 1843, convém que V. M. me informem quais os bens que porventura antigamente possuíam os mesmos índios nesse município, quem dos mesmos está de posse, e por que titulo ou maneira, e qual a denominação e extensão dos terrenos, ou de alguma outra propriedade, e bem assim de todos os bens que devem ser próprios nacionais, embora não pertençam aos índios.

Joaquim José da Silveira foi uma das pessoas procuradas para prestar contas. Durante o ano de 1823 ele havia sido o procurador fiscal da Fazenda de Rio Pardo. Chegou pela primeira vez à cidade em 1818. Por mais de trinta anos acompanhou acontecimentos referentes à disputa pelas terras do aldeamento e segundo ele ${ }^{160}$ :

tive a ocasião de ver e saber que a aldeia de São Nicolau distante desta mesma cidade três quartos de légua mais ou menos, era habitada por índios naturais e se a memória não me falha, creio que me foi dito pelo finado visconde de Pelotas, o então comandante desta fronteira, ser a mencionada aldeia e terras adjacentes em distância até a estrada que se segue para o arroio do Couto, frente ao sul, patrimônio dos mesmos índios.

Joaquim Silveira informou que enquanto exercia o cargo de procurador the foi enviada uma relação das terras do aldeamento feita pelos "próprios nacionais existentes nesta cidade, em a qual veio incorporada um potreirinho". Não sabendo a que terras se referiam aquele potreiro, ele foi se informar com o juiz de paz, Joaquim José da Fonseca e Souza Pinto. O juiz de paz naquela ocasião viria a ser, anos mais tarde, o diretor do aldeamento de São Nicolau. Quando Joaquim Silveira respondeu ao ofício feito pela Câmara de Rio Pardo em 1849, ele já o era. Na época, o então juiz de paz lhe respondeu

\footnotetext{
159 AHMRP. Fundo: Câmara Municipal, Série: Correspondência. Códice Geral 41, [1849], p. 238.

160 AHMRP. Fundo: Câmara Municipal, Série: Correspondência. Códice Geral 41, [1849], p. $237-243$.
} 
que aquelas terras eram as "da várzea da mesma aldeia na costa do rio Pardo, porém que não era pertencente à nação, e sim aos naturais daquela aldeia". Joaquim Silveira considerou a informação insuficiente e procurou pelos títulos das terras que os índios possuíam. Apenas foi informado que aquele patrimônio lhes havia sido doado pelo governador do Continente, e que o potreiro ainda não estava destruído por ainda ser considerado como pertencente à "nação como próprio nacional" 161 .

Outra pessoa para quem a Câmara solicitou informações sobre as terras de São Nicolau do Rio Pardo foi o diretor da aldeia, que assentiu em "religiosamente informar o que sei a respeito" 162 . Impressiona a quantidade de nomes de políticos e religiosos que teriam se apossado das terras, assim como a descrição dos meios usados para isso. Os propósitos de conseguir lotes na aldeia variavam entre estabelecer moradias, fazer plantações, matadouros e chácaras. "Segundo consta de um antigo livro que existe em meu poder" ${ }^{163}$, a aldeia havia sido criada na década de 1770 por José Marcelino de Figueiredo e medida, demarcada e tombada em 1821 e $1822^{164}$. A partir de então, várias personagens conhecidíssimas na história regional teriam se apossado, comprado e vendido lotes de terras de São Nicolau do Rio Pardo, entre elas, o visconde de Pelotas, Rafael Pinto Bandeira, o padre José Alexandre da Fontoura, o conde da Figueira e o próprio diretor do aldeamento, Joaquim José da Fonseca e Souza Pinto. Algumas negociações contaram com a participação dos índios. Uma delas parece ter sido feita envolvendo um guarani de nome João Soares, mediante a qual ele teria vendido uma chácara, e o comprador teria conseguido 'expandir' seus limites com plantações, com a permissão do administrador do aldeamento. Assim segue a lista de apropriações ${ }^{165}$ :

\footnotetext{
161 Os três últimos trechos foram retirados do mesmo documento supracitado. IDEM, 1849, p. 237-243.

162 AHMRP. Fundo: Câmara Municipal, Série: Correspondência. Códice Geral 41, [1849], p. 237-243.

163 IDEM.

${ }^{164}$ Há algumas imprecisões neste documento com relação as datas e à demarcação das terras do aldeamento. Não se sabe ao certo como as informações foram recolhidas e registradas. De todo modo, as confusões existentes denotam a dificuldade das autoridades em apurar dados sobre a propriedade e a desapropriação das terras.

165 IDEM.
} 
Manoel Ferreira da Fonseca apossou-se, durante a revolução da província de uma chácara intitulada de Nossa Senhora, onde os índios faziam sua plantação em comum. Existem mais uma chácara de Antônio do Couto Pereira, hoje de sua viúva e filhos, uma dita de Rafael Oliveira Chaves, comprada a Policárpio Vieira, uma casa de Antônio de Moura no passo do Couto, e um terreno incorporado à chácara de José de Barros, que dele goza, e ignoro de que modo o houve. Lourenço Sacarello arrendou um terreno e nele fundou um matadouro, e um ano pagou arrendamento, falecendo porém, seu irmão João Sacarello dele apossou-se. A chácara do finado major Sebastião José de Oliveira apesar de estar fora dos limites da aldeia, foi acrescentada com terras desta, por consentimento do comandante de então, o major Paulo Nunes da Silva Jardim em 1813 ou 1814. Na praça da mesma aldeia há uma casa pertencente, outra a João Luiz da Silva e outra a Maria Inácia da Silva; tendo sido estes terrenos comprados e cedidos aos vendedores pelas autoridades então constituídas.

Ao todo, cerca de trinta pessoas estiveram envolvidas com a concessão, apropriação, compra e venda das terras do aldeamento de acordo com as informações do seu diretor ${ }^{166}$. Sob a propriedade do aldeamento como 'próprio nacional' restaram poucos bens, entre eles um lote próximo à estrada de ferro e as casas que serviam de prisão e quartel, que por estarem muito arruinadas "a nação a mandou reedificar e que ainda não está concluída para ser completa" 167.

Até 1850 , quando houve a Lei de terras, a concessão dos lotes ainda não havia sido substituída pela venda. As autoridades constituídas podiam doar datas. O regulamento de 1854 deixou a cargo da Repartição Geral das Terras Públicas todos os assuntos referentes a terra, o que não facilitou a administração por parte do Estado. Para mencionar algumas das atribuições da dita Repartição, podemos citar a medição, divisão e descrição de terras devolutas das Províncias, assim como sua conservação, venda e distribuição; e colonização nacional e estrangeira ${ }^{168}$. Ela estava ligada ao Ministério e Secretaria de Estado dos Negócios do Império e era responsável por tantas ordens e tarefas, que sua organização se

\footnotetext{
166 "A aldeia de São Nicolau na sua maior largura terá três quartos de légua, e em circuito duas léguas, mais ou menos, divide-se pelo norte com os matos do Rincão denominado d'El Rei, pelo sul com o barro vermelho, pelo leste com a estrada de São Miguel até o passo velho do Couto, e pelo oeste com o Rio Pardo". IDEM. Durante o período imperial as medidas das terras nem sempre eram convenções, de modo que é arriscado fazer conversões. Se considerássemos as informações fornecidas pelo diretor do aldeamento a respeito da extensão das terras do aldeamento a estimativa seria de uma área de aproximadamente $60 \mathrm{~km}^{2}$, sem contar com os quatro ervais dos índios na serra geral.

${ }^{167}$ IDEM.

${ }^{168}$ KLIEMANN, Luiza H. Schmitz. Op. Cit. p. 21
} 
tornava complexa, para dizer o mínimo. E tais problemas e dificuldades agrárias persistiram até o período republicano. Voltemos à listagem enviada pelo diretor de São Nicolau do Rio Pardo à Câmara da cidade ${ }^{169}$ :

Finalmente pertencem aos índios quatro ervais na serra geral, um deles comprado ao falecido Luis Antônio da Silveira com título e escritura, e tem de frente oitocentas mil braças e de fundo menos de mil e quinhentas, e os outros três intitulados do Pereira, Araçá, e Cruz, os quais compreenderiam pouco mais ou menos em meia légua e que destes só tinham um antiqüíssimo poço, porém de todos apossou-se Elautério Rodrigues Lima, por meio de uma medição que mandou proceder e se não tem podido reivindicar ${ }^{170}$.

Elautério Rodrigues Lima se apossou dos quatro ervais do aldeamento. Algumas posses possuíam título e escritura, mas os índios não parecem ter sido devidamente ressarcidos. Diante daquele cenário, o diretor de São Nicolau do Rio Pardo propôs o aumento do rendimento da receita do aldeamento ${ }^{171}$ :

Na aldeia de São Nicolau os moradores vizinhos da mesma têm nos campos dela porção de boiada e cavalos mansos, por isso ordenei ao diretor interino que cobrasse 640 réis por ano de cada cabeça de animal, isto para rendimento da mesma aldeia, espero que $V$. Ex. aprove esta minha deliberação se achar de justiça. Igualmente participo a V. Ex. que o empregado público João Inácio de Oliveira tem se prestado ao serviço desta diretoria na escrituração dela com inteligência e sempre pronto.

Dificilmente os índios teriam sido recompensados pelo 'aluguel' de suas terras por parte de terceiros, haja vista que a documentação indica que seus vizinhos se achavam donos das mesmas e não arrendatários. Embora os direitos territoriais dos índios estivessem vinculados, já naquela época, aos seus antecedentes e direitos históricos, suas terras eram alvo de disputas ligadas à expansão do capitalismo. Estavam sendo doadas desde a terceira

\footnotetext{
169 AHMRP. Fundo: Câmara Municipal, Série: Correspondência. Códice Geral 41, [1849], p. 237-243.

${ }^{170}$ Pode ser que o diretor tenha cometido algum equívoco. Provavelmente, o erval tivesse oitocentas braças de frente, ao invés de oitocentas mil.

${ }^{171}$ AHRS. Fundo Indígenas. Diretoria Geral dos Índios. Correspondência ativa: José Joaquim de Andrade Neves, 23 junho de 1849.
} 
década dos oitocentos, como nos mostra o requerimento de Miguel Guaraci. Mesmo diante da dificuldade em manter a posse de seus territórios, não encontrei indícios de que eles tenham optado unicamente por se embrenhar nas matas. Tanto nessas primeiras décadas, quanto em meados do século XIX, há elementos que apontam a presença de índios guaranis fora do aldeamento, na cidade de Rio Pardo e outras localidades. Eles movimentaram redes de sociabilidade com outros índios, autoridades políticas e particulares, em lugares fora do aldeamento, como por exemplo, o vale do Rio Pardo.

\section{5 - IMIGRANTES ALEMÃES NO VALE DO RIO PARDO}

A chegada dos primeiros imigrantes alemães na região do vale do Rio Pardo foi um dos prováveis motivos pelos quais os vereadores da Câmara da cidade necessitavam de informações sobre os títulos e a posse das terras do aldeamento de São Nicolau naquele ano. Assim, em meados do século XIX havia novos e antigos sujeitos envolvidos nas disputas pelas terras e pelas atividades econômicas, sociais e políticas que 'dependiam' da posse das mesmas. Militares, famílias de brasileiros e alemães recém-chegados ao vale do Rio Pardo, autoridades políticas e religiosas buscaram conseguir lotes ou benfeitorias do aldeamento. Elas não estavam restritas somente ao território onde o aldeamento existiu, mas também aos ervais na serra geral. Em 1849, foi fundada a colônia de Santa Cruz para receber os imigrantes alemães. Em sua grande maioria agricultores, os alemães estavam em busca de terras onde para o cultivo de gêneros alimentícios. Os lotes eram cedidos pelo governo mediante as seguintes diretrizes ${ }^{172}$ :

\footnotetext{
172 AHRS, Fundo Indígenas, Diretoria Geral dos Índios. Diversos: Papéis relativos a terras do aldeamento de São Nicolau. $3^{\text {a }}$ Diretoria de Terras Públicas e Colonização, seção Rio de Janeiro, Ministério dos Negócios da Agricultura, Comércio e Obras Públicas em 18 de junho de 1857.
} 
Fica $V$. Ex. autorizado a mandar medir e demarcar dividindo em lotes agrícolas as terras do aldeamento de São Nicolau para serem concedidas aos colonos que procurarem essa Província para se estabelecerem, mediante as disposições do Regulamento para as colônias do Estado, ou mesmo aos nacionais que as queiram cultivar, reservando, porém, as que forem precisas para os índios do mencionado aldeamento, segundo $V$. Ex. propõe em seu oficio de 15 de maio próximo findo não respondido.

Nesses lotes os alemães cultivavam principalmente milho, feijão e batata doce. Até o final do século XIX, porém, foi extraída da colônia de Santa Cruz a maior quantidade de erva-mate exportada pela Província. No início da República, ela foi considerada a segunda colônia mais próspera do estado, depois de São Leopoldo ${ }^{173}$. Assim, a valorização e a procura por essas terras cresciam cada vez mais. Mas as concessões dos lotes atravessaram percalços, envolveram disputas acirradas e negociações suspeitas. Nesse contexto, as menções às leis e ofícios que inteiram e reiteram a extinção do aldeamento são muitas e perpassam parte significativa da documentação analisada. Para não correr o risco de dar uma informação equivocada, opto por citar neste e em outros capítulos as referidas leis e ofícios aos quais pude ter acesso ${ }^{174}$ :

A lei provincial $n^{\circ} 493$ de 11 de junho de 1862, anterior a providência de obter do governo imperial a concessão das terras pertencentes à aldeia de São Nicolau no município do Rio Pardo para nestas estabelecer uma colônia e fazenda para a distribuição e venda dos passos na forma da lei $n^{\circ} 304$ de 30 de novembro de 1854, dando preferência às famílias brasileiras e laborosas. A lei $n^{\circ} 603$ de 10 de janeiro de 1867 em seu artigo 29 recomenda a execução daquela lei ( $n^{o}$ 493) com urgência.

O coronel Rodrigo José de Figueiredo Neves encaminhou repetidas petições à presidência da Província a fim de adquirir terras do aldeamento. Assim também o fizeram João Nicolau Falkenbach e Joaquim José da Fonseca e Souza Pinto, seu diretor. Tantas foram as vezes que encaminharam petições requerendo terras do aldeamento que o

\footnotetext{
${ }^{173}$ KLEIMANN, Luiza H. Schmitz. Op. Cit. p. 56.

${ }^{174}$ AHRS. Fundo Indígenas. Diretoria de Aldeamento. Aldeia de São Nicolau. Diversos, maço 2, 1871.
} 
delegado encarregado das terras públicas, cansado dos pedidos e não conseguindo efetuar a medição dos lotes informou numa carta ao presidente da província o seguinte ${ }^{175}$ :

Sobre a pretensão do coronel Rodrigo José de Figueiredo Neves com vista no incluso requerimento que devolvo cumpre-me dizer que a $\mathrm{V}$. Ex. que nada tenho a adicionar à informação que tive a honra de encaminhar a essa presidência em ofício $n^{\circ} 21$ de 27 de fevereiro do ano vigente, a respeito de petição idêntica de João Nicolau Falkenbach e Joaquim José da Fonseca e Souza Pinto.

Nessas disputas pelas terras do aldeamento ocorreram jogos de poder nos quais se nota uma grande complexidade envolvendo a noção da posse de terras por parte dos índios e simultaneamente delas como propriedade da nação. A confusão que girava em torno do que era tido como 'próprio nacional' durou até o período republicano. Pela constituição de 1891 foram considerados nacionais os terrenos "indispensáveis para a defesa das fronteiras, fortificações, construções militares e estrada de ferro federais" ${ }^{176}$. De fato, as poucas áreas de São Nicolau do Rio Pardo que não foram cedidas ou vendidas correspondiam às da prisão, da casa de guerra e da área onde passava a estrada de ferro: "Um único lote, que ficou sobre as cabeceiras do arroio São Nicolau, ainda se conserva por vender, se bem que cortado pela linha da estrada de ferro, onde se edificou uma estação bem desnecessária" 177 . Em 14 de julho de 1867, o delegado encarregado das terras públicas recebeu ordens para mandar medir terras em São Nicolau do Rio Pardo. Porém, em outro ofício, anos mais tarde, declarava que ${ }^{178}$ :

Legitimadas, as posses são pertencentes aos índios que porventura possam ali existir, sujeitas a legitimação, poucas serão as sobras de terras devolutas que se tenham de apurar, sendo que de preferência deverão então ser vendidas em ata pública. Não obstante essa informação foram indeferidos os requerimentos de Rodrigo Jose Figueiredo Neves, Jacob Graeff, João Henrique Eichemberg, despacho de 27 de novembro de 1869, quando pretenderam comprar parte das terras devolutas de São Nicolau.

\footnotetext{
${ }^{175}$ AHRS. Fundo Indígenas. Diretoria de Aldeamento. Aldeia de São Nicolau. Papéis relativos às terras do aldeamento, maço 2, 1871.

${ }_{177}^{176}$ KLEIMANN, Luiza H. Schmitz. Op. Cit. p. 122-123.

177 AHMRP. Fundo: Câmara Municipal, Série: Correspondência. Códice Geral 84, [1887], p. 135 v.

178 AHRS. Fundo Indígenas. Diretoria de Aldeamento. Aldeia de São Nicolau. Papéis relativos às terras do aldeamento, maço 2, 1871.
} 
Neste mesmo ofício é perceptível a dificuldade de aplicação das leis de concessão das terras do aldeamento. Havia incongruências na ocupação de terras 'devolutas' que eram propriedades dos índios. Apesar de serem constantemente medidas e demarcadas para serem ocupadas por colonos e nacionais, era complicado obter a posse das terras e promover a colonização devido a presença dos índios ${ }^{179}$ :

Tendo a presidência da província solicitado do governo imperial a concessão de terras da aldeia de São Nicolau, município de Rio Pardo, para nelas estabelecer a colônia agrícola de que trata a lei provincial $n^{\circ}$ 493 de 11 de janeiro de 1862 por aviso do Ministério da Agricultura a 29 de dezembro do mesmo ano, que por enquanto não podia ser atendido aquele pedido. A lei provincial $n^{\circ} 603$ de 10 de janeiro de 1867, no artigo 29, mandou dar execução a de $n^{\circ} 493$ citada, e pediram de novo as terras de São Nicolau por aviso de 18 de junho foi a presidência de novo autorizada a mandá-la demarcar e medir, dividindo em lotes agrícolas para serem concedidos aos colonos e aos nacionais, reservando porem as terras precisas para os índios do aldeamento.

As disputas por terra aumentavam com o incentivo dado à imigração em algumas partes do país. No Rio Grande do Sul, as chamadas comissões verificadoras passariam a atuar na fiscalização dos assuntos fundiários em $1891^{180}$. Mas devido ao crescente interesse pelas terras do aldeamento e às novas levas de imigrantes alemães que procuravam pelas regiões mais valorizadas, somadas às suspeitas de fraudes na medição e venda de lotes, a colônia de Santa Cruz sofria intervenções antes mesmo do decreto de 1891. Nos trabalhos de verificação e discriminação de terras públicas sobre a divisa de oeste e noroeste de Santa Cruz com o município de Rio Pardo ${ }^{181}$, iniciados em janeiro de 1897 , o governo descobriu fatos que causaram um verdadeiro estardalhaço na região. $\mathrm{O}$ encarregado da comissão começou o relatório deixando clara a sua indignação ${ }^{182}$ :

\footnotetext{
${ }^{179}$ IDEM.

${ }^{180}$ KLEIMANN, Luiza H. Schmitz. Op. Cit. p. 56.

181 AHRS. Obras Públicas. Secretaria de Estado de Negócios das Obras Públicas. Anexo ao Relatório [18971898].

${ }^{182}$ IDEM.
} 
Era um verdadeiro caos o estado das terras e causa surpresa a confrontação dos dados constantes nos autos e plantas com a realidade que se encontra no terreno. Quanta inverdade, fantasia e audácia por parte dos que fizeram tais serviços adulterando a verdade e [ilegível] a boa fé daqueles que por fatalidade lhes eram entregues.

Segundo ele havia medições feitas em detalhes, mas a minúcia dos autos e das plantas era a única coisa de que consistiam, pois "na verdade não foram executadas e sim feitas em gabinetes" 183 de modo que não era possível confrontar os dados com os do terreno. As medições feitas nas terras que, na ocasião, pertenciam aos municípios de Soledade, Rio Pardo e Santa Cruz, durante a década de 1870, "são em seu maior número muito defeituosas, circulando a seu respeito as notícias mais extravagantes, como por exemplo a do emprego da acústica, para determinar-se o cumprimento das linhas" ${ }^{184}$.

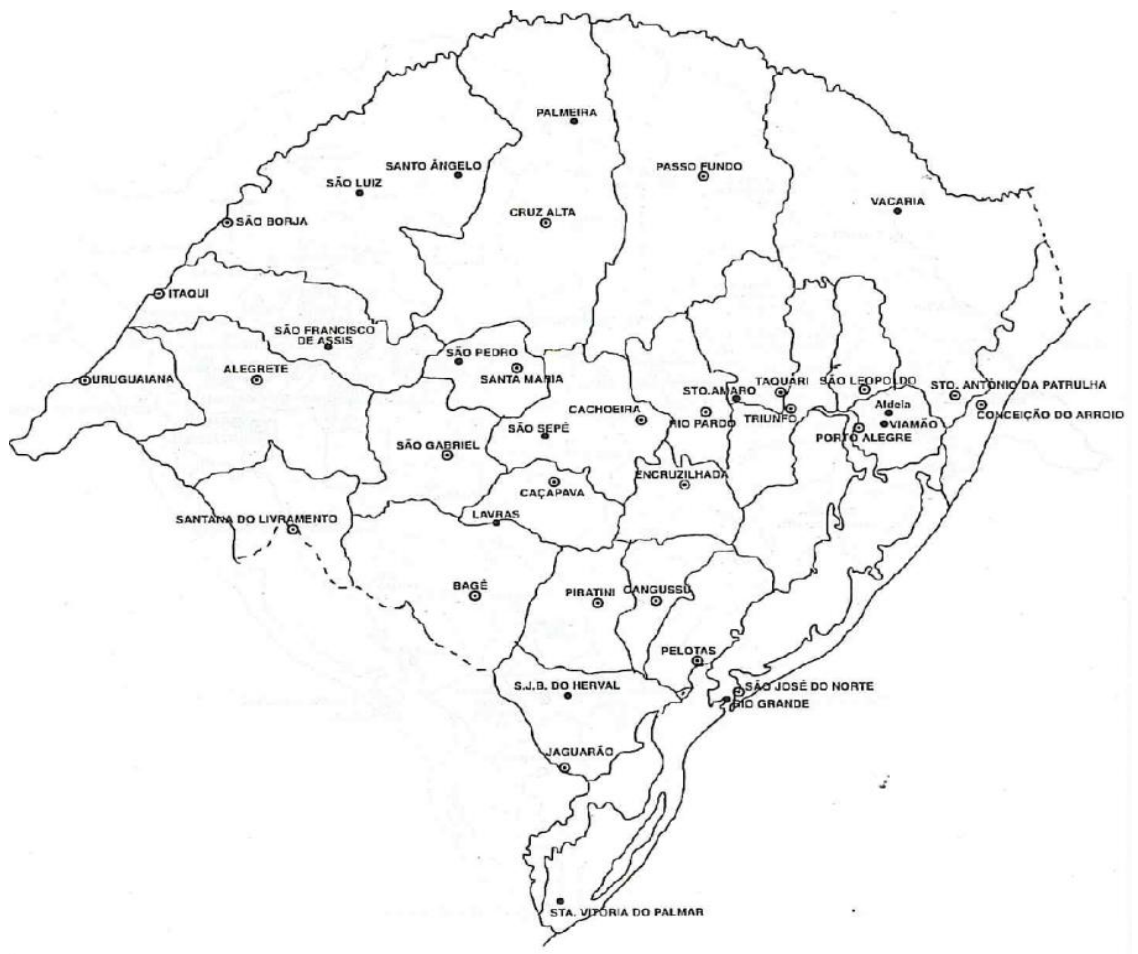

IMAGEM 8 - Mapa dos municípios do Rio Grande do Sul em 1858

Fonte: FELIZARDO, Júlia. (Org.) Evolução administrativa do Rio Grande do Sul. (Criação dos Municípios). Porto Alegre: Instituto Gaúcho de Reforma Agrária (IGRA), Divisão de Geografia e Estatística, p. 19. APUD: FÉLIX, Loiva Otero. Coronelismo, borgismo e cooptação política. Porto Alegre: Editora da Universidade/UFRGS, 1996 [1987], anexo 4.

\footnotetext{
183 IDEM.

${ }^{184}$ IDEM.
} 
Segundo o comissário, os indícios das primeiras fraudes remetiam à década de 1850, quando provavelmente a lei que exigia a compra das terras ao invés da doação delas não teria sido bem aceita entre aqueles que as adquiriam. Na época, segundo o próprio comissário, pouco se cogitava sobre a legitimidade das escrituras. O mesmo não acontecia quando a posse era dos índios, como vimos. Os funcionários do governo estavam envolvidos com as fraudes ${ }^{185}$ :

Cometendo-se os maiores erros nos tais trabalhos, abusando-se ou desrespeitando-se as leis que regem o assunto e somente para saciar a usura de alguns indivíduos, os quais faziam as despesas das legitimações de combinação com aqueles a quem o governo havia confiado o cargo de representá-lo na condição de juiz comissário e que este, ao invés de interpretar, cumprir e fazer cumprir a lei convertia-se em mercador, combinando com os mais funcionários, negociando terras nacionais da maneira mais escandalosa.

O comissário encarregado verificou a existência de formas consideradas públicas para o registro das posses de terras. Junto aos autos, como documentos comprobatórios, havia registros nos livros das paróquias, mas ele descobriu que os números dos livros, dos registros e das folhas eram falsos se comparados com os livros originais do arquivo da comissão. As assinaturas dos documentos não eram sequer semelhantes. A única explicação encontrada por ele foi a de que, além da corrupção dos funcionários do governo, havia registros, escrituras, plantas e medições na mão de particulares e "sendo assim existe mais este crime impune". Em alguns casos, aos verdadeiros proprietários das terras foi garantida uma área de 50 a 100 hectares pelo negócio efetuado, outros tiveram que pagar uma anuidade pelas terras vendidas ilicitamente. Nem sempre tais proprietários estavam cientes das irregularidades que envolviam as negociações. Segundo o comissário as terras eram “obtidas fraudulentamente aos incautos", que eram convencidos de que a colonização "lhes incomodaria nos labores de suas vidas porque quase todos se dedicam ao fabrico da ervamate e alguma criação" 186 .

\footnotetext{
185 IDEM.

${ }^{186}$ IDEM. Os três últimos trechos foram extraídos deste mesmo relatório.
} 
Houve outra descoberta que causou escândalo envolvendo o sobrenome Eichemberg e a produção ervateira. Jorge Júlio Eichemberg era proprietário de uma grande quantidade de terras destinadas à produção de erva-mate sem que os títulos e as escrituras de compra e venda das mesmas fossem autênticos. Alguns dos requerimentos encaminhados por Eichemberg estavam em nomes de posseiros inexistentes, segundo o encarregado da excolônia. A justificativa para o interesse pelas terras era a de alojar indivíduos que o governo havia expulsado das terras destinadas a colonos. As concessões foram deferidas em meados do século XIX pelas autoridades da presidência da Província e de Rio Pardo, mas como as terras permaneceram abandonadas, foram ocupadas por pessoas que passaram a se dedicar à exploração da erva-mate. Jorge Júlio Eichemberg procurou os concessionários (que realmente existiam) comprando-lhes as terras a preços baixíssimos, já que os ocupadores das terras não possuíam os títulos. Em seguida, providenciou sua venda para outros colonos que desconheciam o enorme problema do qual passariam a fazer parte. Em 1891, fundou-se a Companhia Eichemberg. No ano de 1898, as vendas das terras da Companhia foram postas em dúvida quanto à sua legitimidade. O chefe da comissão considerou, como para os outros casos, que as medições e as plantas dos terrenos haviam sido forjadas em gabinete, com a óbvia participação de funcionários do governo ${ }^{187}$. Em 1898, os ervais foram destruídos e os lotes de terra redistribuídos a colonos.

A questão que teve sua origem em meados do século XIX, com a chegada dos alemães e as leis sobre a extinção do aldeamento de São Nicolau do Rio Pardo perdurou por mais de cinqüenta anos. Quando as comissões demarcadoras entraram em ação (em 1891) e as fraudes foram denunciadas, a produção ervateira decaiu e algum tempo depois Santa Cruz passou a investir no cultivo do fumo. De acordo com a historiadora Luiza Kliemann ${ }^{188}$, este episódio tomou grandes proporções, ultrapassou o âmbito dos gabinetes e foi parar nas páginas dos jornais de Santa Cruz. Quando a colonização por parte da Companhia Eichemberg foi suspensa, aqueles considerados intrusos receberam um aviso através deste mesmo jornal, chamado Die Colonie. Eles ${ }^{189}$

\footnotetext{
187 IDEM.

${ }^{188}$ KLIEMANN. Op. Cit. p. 56-59.

189 ASUP (Arquivo Sociedade União Popular). Edital de 9 de setembro de 1898. Die Colonie, Santa Cruz do Sul, 1898, p. 3-4. APUD: KLIEMANN, Luiza H. Schmitz. Op. Cit. p. 58.
} 
eram considerados como colonos e devedores das importâncias das terras que ocupam, aos cofres públicos do Estado; por isso e de conformidade com os regulamentos respectivos em vigor convida-se os mesmos a saldarem os seus débitos no menor prazo possível, a fim de obterem os títulos definitivos.

Neste mesmo relatório de comissão e verificação de terras em Santa Cruz, Rio Pardo e Soledade, há um mapa onde consta a chegada de trezentos guaranis em sessenta e oito famílias a Porto Alegre, entre os meses de janeiro e junho do ano de 1898, quando os trabalhos terminaram. O quadro demonstrativo traz dados numéricos sobre "o destino que tomaram durante o primeiro semestre do corrente ano os colonos que se achavam nesta capital sem meios de subsistência" ${ }^{190}$. Toda aquela situação levou funcionários da secretaria de Obras Públicas, Terra e Colonização do Estado a perceberem os índios como colonos, motivo pelo qual não seria difícil vê-los como misturados e compreender seus destinos como mesclados aos da sociedade nacional.

Poucas posses se achavam devidamente legitimadas quando os serviços da comissão verificadora foram encerrados, entre elas, a de Abrahão Tatsch. Nas palavras do comissário ele não pôde "deixar de mencionar o caso" no relatório. A subdivisão das terras do Sr. Tatsch "foi tão desastrada que não só invadiu terras devolutas como também terras dos lotes da linha da Serra, lotes estes que na maior parte já estão pagos pelo governo, e os colonos de posse dos respectivos títulos" ${ }^{191}$. O fato teria tido consequiências desagradáveis para os colonos, que já estavam desconfiados da invasão de cerca de 600 metros em suas propriedades. Os antigos habitantes dessa área estavam sendo intimados pelos seus vizinhos a deixarem as terras, porém, "baseados nas escrituras de compras, entendem que não devem ceder" ${ }^{192}$. Para o comissário era preciso regularizar esse fato com urgência, pois as terras haviam sido compradas em boa fé a Abrahão Tatsch. Esse episódio revela que indígenas e imigrantes alemães tiveram suas terras invadidas em algumas situações, assim como invadiram as de outrem.

\footnotetext{
${ }^{190}$ AHRS. Obras Públicas. Secretaria de Estado de Negócios das Obras Públicas. Relatório [1897-1898]. Diretoria de Obras Públicas Terra e Colonização, $2^{\mathrm{a}}$ seção, julho de 1898.

${ }^{191}$ AHRS. Obras Públicas. Secretaria de Estado de Negócios das Obras Públicas. Anexo ao Relatório [18971898].

${ }^{192}$ IDEM.
} 
Contudo, há ainda aspectos encobertos nas histórias vividas pelos índios guaranis e imigrantes alemães, ambos habitantes da região de Rio Pardo. Um exemplo é a história de Leoncina Tatsch, que nasceu na aldeia de São Nicolau e faleceu em Porto Alegre com 103 anos, de acordo com seus familiares. Na década de 1920 ela se casou com Leopoldo Germano Tatsch, descrito por ela como "um alemão que costumava passear pela aldeia a cavalo". Logo depois de se casarem foram morar no Rincão d'El Rei, lugar próximo ao aldeamento, onde tiveram dez filhos. A lembrança mais viva que Leoncina preservava em sua memória sobre São Nicolau do Rio Pardo era a igreja. Ela se “dava com todo mundo lá na igreja, quando morava na aldeia”. A extensa família de Leoncina costuma atribuir sua longevidade ao "sangue de bugre que ela tem", assim como o de sua mãe, que nasceu e faleceu em São Nicolau do Rio Pardo. A filha mais velha de Leoncina é Eloy, com quem ela morava em Porto Alegre. Eloy, que também nasceu em São Nicolau do Rio Pardo, guarda uma lembrança do lugar: o "mate doce que a vó preparava" 193.

\footnotetext{
${ }^{193}$ Os últimos trechos foram retirados de entrevista oral concedida por Leoncina e Eloí Tatsch em 27 de
} agosto de 2010, na cidade de Porto Alegre. Leoncina Tatsch faleceu cerca de três meses após esse encontro. 


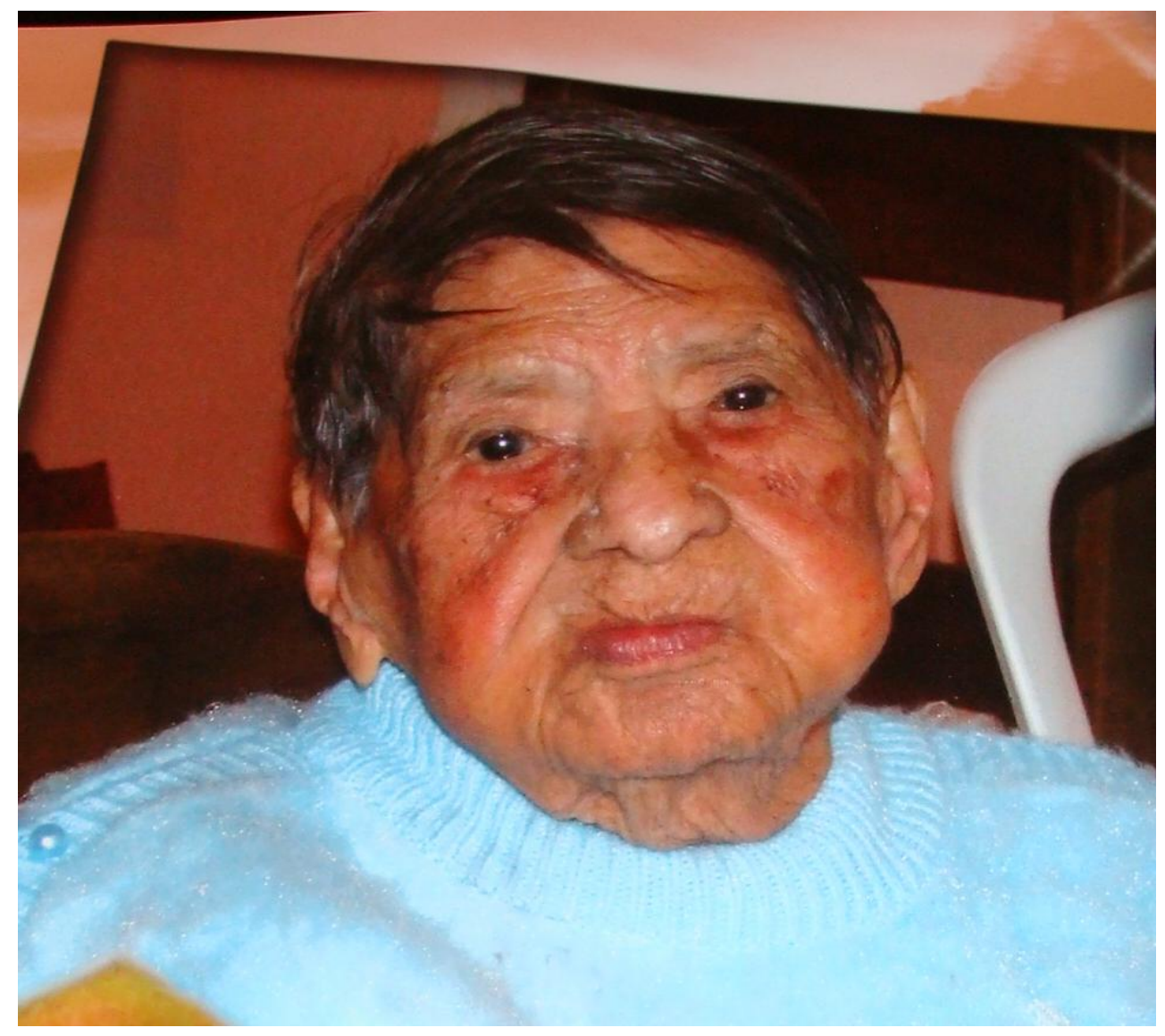

IMAGEM 9 - Leoncina Tatsch, quando comemorou 102 anos, no ano de 2009.

Fonte: Álbum de fotos de família ${ }^{194}$.

As entrevistas com Leoncina e Eloy Tastch não revelam maiores detalhes e informações sobre a vida dos índios e dos moradores de São Nicolau do Rio Pardo durante o século XIX. Contudo, não deixa de ser interessante o fato de que elas mencionem a ascendência indígena e alemã, a religiosidade cristã, e o consumo de erva-mate quando, de fato, se sabe que houve um intenso contato e circulação de bens e pessoas no aldeamento onde mãe e filha nasceram. Histórias fragmentadas como esta, revelam aspectos importantes das experiências vividas por imigrantes alemães, moradores de São Nicolau do Rio Pardo e seus descendentes. Podemos perceber que elas foram numerosas e variadas, e esses fragmentos precisam ser, à medida do possivel, reconstruídos. Fontes escritas e fontes orais não costumam oferecer respostas prontas para as perguntas que os pesquisadores

\footnotetext{
${ }^{194} \mathrm{O}$ uso desta imagem foi cedido para esta pesquisa.
} 
fazem sobre seu objeto de estudo. Não foram registradas com tal propósito. Mas, mesmo que seja por meio de informações esparsas, como no caso das entrevistas feitas com Leoncina e Eloy Tastch, suscitam reflexões importantes sobre a escrita da história dos índios. O tempo pode se apresentar como o outro para o historiador, assim como os índios podem se apresentar como os outros para os antropólogos. Mas entre o 'nós' e os 'outros' existem tantas questões capazes de ultrapassar categorias étnicas que as fronteiras que os separam tornam-se, às vezes, muito tênues.

\section{6 - CULTURAS E PRÁTICAS EDUCACIONAIS}

Diferentes tipos de demandas e atitudes fizeram parte dos jogos de poder nessas disputas territoriais. O ensino de práticas 'civilizadoras' era uma delas. O aldeamento de São Nicolau do Rio Pardo manteve uma escola de primeiras letras para o ensino exclusivo de meninos guaranis ao longo de boa parte do século XIX. A aldeia de Nossa Senhora dos Anjos havia possuído uma escola para os meninos e um recolhimento para meninas indígenas ${ }^{195}$, mas ambos foram extintos ao final do século XVIII. Através dos colégios e dos recolhimentos o objetivo da política indigenista do século XVIII era integrar os indígenas através da eliminação de alguns de seus traços culturais, como a língua e a 'religião'. Conforme dito anteriormente, a política indigenista do século XIX manteve muitas disposições presentes no projeto pombalino de assimilação e integração indígena. Uma delas foi a manutenção de escolas e do ensino da catequese nos aldeamentos. No caso analisado, a prática de ensino não serviu, necessariamente, para assimilá-los. As fontes acessadas indicam que São Nicolau do Rio Pardo foi o único entre os demais aldeamentos existentes na Província a gozar dessa prerrogativa. Parece ter havido práticas de ensino em alguns outros aldeamentos, mas não num espaço físico destinado para isso, ou através de missionários remunerados pelo governo para tal função. Na escola de São Nicolau do Rio

\footnotetext{
${ }^{195}$ MELO, Karina M. R. S. e. “A aldeia dos Anjos durante a década de 1770: um olhar sobre as relações entre os indígenas e os portugueses”. Raízes de Gravataí: memória, história e cidadania. TOMO I. JACHEMET, Célia Silva, BARROSO, Véra Lucia Maciel. Gravataí: Prefeitura Municipal: Casa dos Açores do Rio Grande do Sul. Porto Alegre: EST: Evangraf, 2011, p. 79.
} 
Pardo ensinava-se português, aritmética e música. Provavelmente, ela tenha funcionado até o ano de 1865. Os documentos existentes são referentes aos anos de 1848, 1854 e 1865, mas não se sabe se este último corresponde ao seu derradeiro ano de funcionamento; tampouco é possível saber sobre os dados de todos os anos letivos em que a escola se manteve aberta.

Os mapas sobre as aulas no aldeamento trazem dados sobre os alunos, sua filiação, freqüência e desempenho nas atividades escolares. $\mathrm{O}$ do ano de 1848 está parcialmente queimado e divido em pedaços ${ }^{196}$. Apesar de despedaçado, o mapa traz informações inéditas e importantes sobre o aldeamento e a escola, além de fornecer pistas sobre histórias de índios guaranis que se movimentavam pela Província durante aquele período. Em $1848^{197}$, dezoito crianças guaranis freqüentaram a escola, mas apenas sete delas era natural de São Nicolau do Rio Pardo. As demais eram nascidas ou eram provenientes de outras localidades da Província como o distrito do Couto, "das Missões", do "Estado Oriental" (assim como se encontra no mapa), e de São José do Patrocínio. O que chama atenção é que mais da metade dos alunos que frequientavam a escola era proveniente do "Estado Oriental", ou seja, do Uruguai. Isso indica que, ao menos em alguns momentos do século XIX, São Nicolau do Rio Pardo se apresentou como um destino possível não somente para os índios guaranis da região das missões e de outras partes da Província, mas também para 'guaranis de outra nacionalidade'. A formação das identidades étnicas dos índios guaranis naquele período esteve estreitamente vinculada à formação de sua própria identidade nacional. Talvez, o fato de guaranis de vários lugares pensarem que na aldeia poderiam conseguir algum tipo de vantagem ou benefício que não conseguiriam fora dela, e também o fato de executarem esses pensamentos na prática, pode ter ajudado na preservação daquele local como um espaço indígena. Dados como esses revelam que a noção costumeira e simplista de que índios aldeados não circulavam e não se relacionavam não se aplica ao contexto histórico analisado. Além disso, revela que a diferenciação estabelecida entre guaranis aldeados e guaranis dispersos ou 'guaranis das matas' não procede para o

\footnotetext{
196 Segundo informações esparsas encontradas nas fontes, nas instalações da aldeia de São Nicolau parece ter havido alguns incêndios, sobretudo em função das guerras provinciais Algumas dessas informações encontram-se em: IHGRGS. DIAS LOPES, Vicente Zeferino. "Comentário Eclesiástico do Rio Grande de São Pedro do Sul desde 1737’. Cópia datilografada. Caixa D, nº 10.

197 AHRS. Fundo Instrução Pública, maço 13, cx. 6. Mapa dos Alunos que freqüentam aula pública de Primeiras Letras de São Nicolau do mês de janeiro de 1848 até janeiro de 1849. São Nicolau, janeiro de 1849.
} 
caso das relações de sociabilidade estabelecidas em São Nicolau do Rio Pardo, visto que muitos dos que vieram não eram procedentes de outros aldeamentos. Desconheço se há o uso de critérios étnicos baseados nesse tipo de diferenciação para o caso dos guaranis que viveram no século XIX. Nas palavras de Juan Carlos Garavaglia ${ }^{198}$ :

Estas versiones sobre la supuesta "vuelta hacia la selva" (selva/oscuridad/diablo/[...]) habla más sobre los demonios que persiguen a esos historiadores, que sobre el destino real de los indios escapados de los pueblos.

As ações indígenas indicam que a volta para a selva, ambiente considerado como uma espécie de habitat natural dos índios, não foi sua única opção. Eles levaram em consideração outras atitudes que eram esperadas deles por parte das autoridades políticas e da própria sociedade envolvente. Mostraram-se conscientes dos benefícios que poderiam obter colocando-as em prática. Isso demonstra o entendimento sobre a necessidade do aprendizado de alguns valores do mundo do outro, que poderiam ser úteis para si naquela situação. Indica que poderiam estar dispostos a negociar esse aprendizado com o intuito de tentar impedir a extinção do aldeamento. De acordo com as fontes consultadas, o maior número de medidas tomadas para a medição, venda e concessão das terras do aldeamento parece ter ocorrido durante as décadas de 1830 e 1860. Quando as ameaças de extinção do aldeamento atingiram um momento crítico, na década de 1850, o mapa sobre a escola mostra que o número de alunos matriculados mais do que dobrou em comparação ao ano de 1848. No ano de 1854, a escola contava com 38 alunos, dos quais 13 eram naturais de São Nicolau e 8 eram naturais da cidade de Rio Pardo. Pode ser que com as sucessivas tentativas por parte do governo provincial de extinguir o aldeamento alguns índios tenham tido e preferido a oportunidade de ir para a cidade de Rio Pardo. Havia quatro alunos vindos do 'Estado Oriental', cinco vindos do distrito do Couto, e oito vindos de Santo Amaro, Viamão, Santana, São Gabriel, Itaquí e São Leopoldo. A procedência desses alunos, em geral crianças entre oito e doze anos, demonstra a circularidade dos índios

\footnotetext{
${ }^{198}$ GARAVAGLIA, Juan Carlos. Op. Cit. p. 190. O autor se refere à fuga dos guaranis-missioneiros após a expulsão dos jesuítas no século XVIII.
} 
guaranis pelo território da Província. Não considero, entretanto, que os índios não soubessem dos limites territoriais impostos à sua circulação, tampouco que sua mobilidade espacial advenha exclusivamente dos seus costumes culturais. Ou ainda, que não fossem capazes de lidar com outro tipo de concepção do espaço por serem índios. Ao contrário, a comparação entre os mapas estatísticos da aldeia de São Nicolau dos anos de 1848 e 1854, demonstra que compreendiam que sua circularidade dependia também de resguardar um espaço territorial que estava sendo constante e politicamente redefinido. Os limites desse território e o controle sobre ele foram fundamentais para os índios guaranis ao longo de todo o século XIX e eles se mostraram cientes da importância de suas ações para mantê-lo. A escola do aldeamento parece ter sido uma das maneiras encontradas no sentido de evitar a extinção, mas não a única ${ }^{199}$ :

Os índios na existente [aldeia] empregam-se uns na lavoura, outros na condução de tropas e carretas e outros nas próximas charqueadas, estando vários menores nesta cidade aprendendo a música e pintura, e os ofícios de ferreiro, carpinteiro e sapateiro.

Eles exerciam o aprendizado de artes e ofícios na cidade de Rio Pardo e se relacionavam com seus moradores. Em alguns casos, tornaram-se também moradores urbanos. Em 1849, por exemplo, mesmo ano em que chegaram à colônia de Santa Cruz os primeiros alemães, meninos guaranis foram enviados à capital ${ }^{200}$ com o propósito de que lá continuassem os estudos que começaram no aldeamento de São Nicolau. Enquanto oportunidades de estudo eram oferecidas aos meninos guaranis, justamente pela sua condição indígena, o mesmo não acontecia com meninas guaranis, nem com crianças alemãs de ambos os sexos. No caso das meninas guaranis, essa pode ser uma das razões pelas quais a presença feminina no aldeamento era tão marcante. No caso das crianças alemãs, aparentemente tinham suas oportunidades cerceadas pela sua condição social e econômica, afinal a maioria dos imigrantes alemães que vieram para o Brasil eram ou tornaram-se agricultores. Avé-Lallemant, durante sua viagem pela Província conversou

\footnotetext{
199 AHRS. Fundo Indígenas. Diretoria Geral dos Índios. Correspondência ativa: José Joaquim de Andrade Neves, 01 de janeiro de 1849.

${ }^{200}$ Não foi possível identificar se no documento a referência era à capital da Província ou do Império.
} 
com alguns deles, recém-chegados à colônia de Santa Cruz. Segundo seu relato, muitos tinham uma vida dura, cheia de privações. As preocupações de uma mãe alemã chamou-lhe a atenção sobre as condições de ensino para os filhos de imigrantes. Ela morava em meio à mata, amamentava seu undécimo filho e ${ }^{201}$

no meio de todas essas fadigas e renúncias, essa senhora só tinha uma preocupação: de que aqui na floresta não houvesse todos os meios para a educação de seus filhos. Entretanto, esses filhos das selvas, de faces rosadas, pareciam tão amáveis e tão graciosamente tímidos diante do estrangeiro, que se lhes poderia perdoar o desalinho (...).

Avé-Lallemant também era alemão, mas se sentiu um estrangeiro perto daqueles a quem chamou de 'filhos das selvas de faces rosadas'. Relacionou a falta de instrução e a localização espacial dos imigrantes alemães à selvageria, e tomando-se como base esse raciocínio muitos guaranis não poderiam ser considerados selvagens. Havia diferenças e semelhanças entre crianças guaranis e os pequenos 'selvagens de face rosada'. Umas delas era o grau de instrução escolar, mais do que propriamente a existência ou a inexistência dela entre ambos. Afinal, não muito distante da colônia de Santa Cruz, filhos de índios guaranis poderiam aprender artes como a música e a pintura, além da instrução em português e matemática. A maioria dos imigrantes alemães falavam apenas seu idioma, ao passo que muitos índios guaranis falavam em guarani, português e espanhol. Aprendiam ofícios que não estavam ligados à atividade agrícola ${ }^{202}$ :

Contém este aldeamento 294 índios de ambos os sexos e idades, freqüentam as aulas de primeiras letras 24 menores, acham-se três menores aprendendo música, 1 a ferreiro, 1 a sapateiro, 1 a carpinteiro, 1 a alfaiate e 3 empregados na Armada Nacional.

\footnotetext{
201 AVÉ-LALLEMANT, Robert. Op. Cit. 1980, p. 172.

202 AHRS. Fundo Indígenas. Diretoria Geral dos Índios. Correspondência ativa: José Joaquim de Andrade Neves, maio de 1850.
} 
O acesso dos índios à educação escolar era baseado em critérios de distinção étnica e política. Eram guaranis e possuíam um histórico de relações com autoridades políticas que lhes rendiam certos benefícios em relação a diversos segmentos sociais. Entre tais segmentos estavam outros guaranis que não estabeleciam quaisquer relações com o aldeamento, índios com outra identidade histórico-cultural ${ }^{203}$, imigrantes alemães e outros brasileiros. É claro que essa distinção por si só não significou que o aprendizado tenha se dado por caminhos fáceis para os índios, como já vimos neste capítulo. Para cada menor que aprendeu um pouco mais sobre música no ano de 1850, houve outro que aprendeu um pouco mais sobre guerras e atividades militares. Aprenderam ofícios que poderiam usar como um saber voltado para o trabalho nas cidades, como a carpintaria, a sapataria e a alfaiataria. A vida urbana poderia se apresentar como um perigo ou como uma oportunidade para esses aprendizes. Em 1850, um daqueles menores que saíram do aldeamento de São Nicolau para aprender ofícios em Rio Pardo teve outro destino. Seu nome era Manuel Lucena e aprendia o ofício de carpinteiro com Antônio José Lopes de Carvalho. Este havia assinado um termo junto à diretoria geral dos índios, sediada em Rio Pardo, para obter uma espécie de guarda provisória do menor. Mas o aprendiz de carpinteiro "foi seduzido por João José Flores, homem de péssimas qualidades e o levou consigo para a campanha a fim de o não entregar" ${ }^{204}$. Uma ordem foi expedida para que a polícia desse conta do paradeiro de Manuel Lucena e o entregasse a Antônio Carvalho. Meses mais tarde o diretor geral dos índios se queixava que nada havia sido feito até então. Entretanto, era sabido que João José Flores se encontrava em sua casa em Cruz Alta ${ }^{205}$ e "por isso espero que V. Ex. ordene para que o referido Flores seja compelido a dar conta e entregar o índio menor que seduziu" ${ }^{206 .}$

Os casos de seqüestro de crianças indígenas foram freqüentes no século XIX, normalmente interpretados como atos de adoção por famílias que, quase sempre, os empregavam em atividades domésticas. Em 1813, Martinho Porará, um índio da "Nação

\footnotetext{
${ }^{203}$ Como os coroados, cujos toldos passaram a receber ensinamentos não exclusivamente catequéticos somente no começo do século XX.

${ }^{204}$ AHRS. Fundo Indígenas. Diretoria Geral dos Índios. Correspondência ativa: José Joaquim de Andrade Neves, 2 de janeiro de 1851.

${ }^{205}$ Cruz Alta é outra cidade da Província, relativamente perto de Rio Pardo.

${ }^{206}$ AHRS. Fundo Indígenas. Diretoria Geral dos Índios. Correspondência ativa: José Joaquim de Andrade Neves, 2 de janeiro de 1851.
} 
Guarani, casado com Maria Simona da mesma Nação e ambos aldeados na aldeia de São Nicolau da Vila do Rio Pardo" ${ }^{207}$, reclamava através de um requerimento o seqüestro de sua filha. A menor chamada Marcelina havia sido violentamente retirada de sua família para ser entregue ao tecelão Francisco Antônio de Vasconcelos, mesmo mediante os protestos dos pais. Martinho Porará e Maria Simona se mostraram indignados com tal atitude e estranharam o uso de tal violência para quem não era escravo. Martinho argumentou que era um vassalo livre como os demais e não merecia tal tratamento, “antes sua Nação merece a vossa contemplação". O casal não aceitou a justificativa de que Marcelina receberia melhor educação com a família de Francisco Antônio de Vasconcelos. Eles questionaram essa alegação veementemente, considerando que Marcelina também poderia ser educada em sua companhia, com a diferença de que seria tratada como filha e não como escrava, procurando se diferenciar das condições sociais impostas pela escravidão. De fato, como o capitão Paulo Nunes da Silva Jardim informava em ofício, Francisco Antônio de Vasconcelos, após requerer a entrega “de dois piás desta aldeia para ele lhes educar e lhes ensinar o ofício de tecelão" ${ }^{208}$ os enviou para a casa de seu sogro. Tendo se ausentado em viagem para o Rio de Janeiro, deixara os dois menores sob os cuidados de sua mulher. Ela enviou o menino para servir a um irmão solteiro 209

o qual tendo uma china em casa, esta maltratou tanto o piá que fugiu. Também me consta que a mulher do dito tecelão não tem bom gênio e não trata bem a chininha, filha do suplicante e nem lhe ensina coisa alguma, antes que se ocupar em embalar as crianças (...).

O ofício de Silva Jardim fora expedido quase dois meses após o rapto de Marcelina. Ele reconheceu que nada era ensinado às crianças. Ainda assim, esperaria que o pedido fosse julgado para proceder à devolução da menina. Podemos notar que havia vários tipos de situações envolvendo a questão da educação dos índios no aldeamento. As aulas ministradas na escola e o aprendizado de ofícios e artes em Rio Pardo faziam parte delas,

\footnotetext{
207 AHRS. Fundos Militares. Requerimentos, maço 9, 1813.

${ }^{208}$ IDEM. Ofício anexo de Paulo Nunes Silva Jardim, capitão diretor. Aldeia de São Nicolau, 4 de fevereiro de 1814. Os grifos são meus.

${ }^{209}$ IDEM.
} 
mas não se restringiam a isso. Tanto o seqüestro de crianças indígenas por moradores que alegavam serem capazes de oferecer-lhes conhecimento, quanto as aulas oferecidas na escola do aldeamento envolveram situações de mobilidade espacial dos índios na Província e no Estado Oriental. Quer dizer, as práticas e as culturas relacionadas à educação foram exercidas tanto pelos índios de São Nicolau do Rio Pardo em benefício próprio, quanto por particulares, que na maioria das vezes, estavam interessados em apropriação de mão-deobra. Vimos que, em alguns casos, a condição indígena que lhes possibilitava o acesso a certos conhecimentos, podia também colocá-los em situações que lhes causavam problemas e sofrimentos, em que pais e crianças guaranis agiram em relação às atitudes de particulares e do governo, como fizeram Martinho Porará, Maria Simona e o menino que fugiu dos maus tratos. É importante enfatizar que havia crianças e adultos guaranis que eram tão ou mais instruídos do que aqueles que pleiteavam dar-lhes educação. E isso contou para que homens, como Martinho Porará pudessem requerer, através dos trâmites legais, a devolução de sua filha. Lembremos também de Miguel Guaraci e de outros requerimentos encaminhados pelos guaranis. Quanto às crianças, à medida do possível procuravam maneiras de lidar com as dificuldades, fosse através da fuga, como pode ter sido o caso do menino seqüestrado junto com Marcelina, fosse através da escolha de 'ser seduzido' como pode ter acontecido com Manuel Lucena. A instrução dos índios em artes musicais e ofícios foi usada por eles em outros acontecimentos, como em alguns conflitos bélicos, assunto que veremos a seguir. 


\section{CAPÍTULO 4 - SOBRE GUERRAS E GUARANIS EM TEMPOS PROVINCIAIS}

“Ore Nhe'e Ambá py guá

Roguereko mba'epú

Xondaro'í ojerojy

Xondaria'í oporaí

Ore Nhe'e Ambá"
Nós todos pertencemos ao Nhe'e Ambá Temos instrumentos tradicionais Os guerreiros dançam, valorizando a cultura As guerreiras cantam, valorizando a cultura

Nós todos pertencemos ao Nhe'e Ambá

Faixa 1 do livro-cd Yvý Poty, Yva'á (2009) Flores e Frutos da Terra

Cantos e Danças Tradicionais Mbyá-Guarani

Nhe'e Ambá - Morada dos Anjos

Xondaro'i kuery kunha karai ra'y'i kuery

Guerreiros e guerreiras,

há'eve'iko - há'eve'iko!

Boa noite - boa noite!

Kova'erã rupi haema nhandekuai i'vy

O nosso trabalho será cantar e dançar, então japorai

tove tanhanembaraete tanhande py'a guaxu

Cantaremos e dançaremos e que Nhãnderú dê

pavé'i kova'ema há'eve'i va'e

força e coragem

A todos nós para seguirmos bem nosso trabalho

Faixa 1 - cd Nhanderú Jepoverá

Cantos Guarani - Cantagalo (2004)

Nhanderú Jepoverá - Raio Sagrado de Deus 


\section{1 - INTRODUÇÃO}

De meados do século XVIII até as derradeiras décadas do XIX podemos elencar vários conflitos bélicos envolvendo os domínios territoriais da Coroa portuguesa e espanhola no sul da América meridional, e posteriormente, da Província de São Pedro e das Províncias Unidas do Rio da Prata, contando conflitos civis. Entre eles destaco a guerra Guaranítica (1754-1756), a chamada "Invasão espanhola" (1763), a conquista das Missões (1801), a guerra Cisplatina (1825-1828), a guerra dos Farrapos (1835-1845), a guerra da Tríplice Aliança (1839-1851) e a guerra do Paraguai (1864-1870). Durante o século XVIII, os eventos bélicos marcaram o modo como os limites fronteiriços foram disputados e definidos pelas Coroas ibéricas na região. Na Província de São Pedro, eles se estenderam ao longo de, praticamente, todo o período oitocentista em decorrência da formação dos Estados Nacionais na região platina. Nos últimos anos, tais conflitos tem sido alvo de importantes estudos históricos ${ }^{210}$, cujas contribuições rompem com os cânones da historiografia tradicional e ampliam seus significados para além das imagens clássicas comumente difundidas sobre eles. O enfoque exclusivo à biografia de "heróis oficiais de guerras" 211 ou a ênfase aos aspectos estritamente militares ${ }^{212}$ foram duramente questionados. Baseadas em amplas pesquisas documentais, novas abordagens tem permitido repensar guerras e revoltas a partir de novos temas e problemas que levam em conta a existência de diferentes culturas políticas, de variados processos de militarização e recrutamento, e de formação de novas identidades políticas ${ }^{213}$ :

\footnotetext{
${ }^{210}$ Para um apanhado de estudos sobre alguns aspectos desses conflitos ver: GRIJÓ, Luis Alberto; NEUMANN, Eduardo Santos (org.). Continente em armas: uma história da guerra no sul do Brasil. Rio de Janeiro, Apicuri, 2010.

${ }^{211}$ Como por exemplo, os estudos de cunho biográfico sobre o marechal Manuel Luís Osório, que atuou na maioria dos conflitos ocorridos na Província de São Pedro. O marechal também se tornou conhecido através dos títulos com que foi agraciado mediante o prestígio político e outros dividendos adquiridos durante as batalhas. O barão e, posteriormente, o visconde do Herval participou da guerra Cisplatina, dos Farrapos, da Tríplice Aliança e da guerra do Paraguai. OSÓRIO, Fernando Luís. História do General Osório. Rio de Janeiro, Typografia de G. Leuzinger \& Filhos, $1^{\circ}$ vol., 1894; Magalhães J. B. (Cel). Osório: síntese de seu perfil histórico. Rio de Janeiro, Biblioteca do Exército, 1977; IDEM. Osório: símbolo de um povo, síntese de uma época. Rio de Janeiro: Livraria AGIR Editora, 1946.

${ }^{212}$ FRAGOSO, Augusto Tasso. A Revolução Farroupilha (1835-1845). Narrativa das Operações Militares. Rio de Janeiro: Almanak Laemmert, 1938; VASCONCELOS, Genserico. História Militar do Brasil. A Campanha de 1851-1852. Rio de Janeiro, Ministério da Guerra, 1941.

${ }^{213}$ BRAGONI, Elsa Beatriz \& MATA, Sara Emilia. Entre la Colônia y la República: insurgencias, rebeliones y cultura política en America del Sur. Buenos Aires, Prometeo Libros, 2008, p. 15.
} 
Lentamente los historiadores retomaron el interés por la dinámica de la guerra especialmente preocupados por el impacto de los ejércitos sobre las economías y sociedades locales. Si bien los trabajos que se ocupan específicamente del inusitado desplazamiento de hombres y del aprovisionamento de ganado y cavallada y la fabricación e compostura de vestimentas y aperos destinados a su abastecimiento - que inevitablemente implicaron redistribución de recursos y riqueza - es aún relativamente escaso, el problema se encuentra ya en la agenda historiográfica(Tío Vallejo, 1998).

A partir dessas novas perspectivas e preocupações outros elementos puderam ser evidenciados e rediscutidos, como a participação de outros setores sociais nas contendas militares, como escravos e libertos ${ }^{214}$, mulheres $^{215}$ e indígenas ${ }^{216}$. Tratando especificamente da participação desses últimos em guerras, os avanços têm sido significativos, uma vez que o caráter histórico das práticas indígenas é posto em evidência através do uso combinado de métodos e perspectivas comuns à história e à antropologia. O método etnohistórico tem possibilitado uma releitura dos processos sócio-históricos pelos quais populações ameríndias passaram $^{217}$.

Neste capítulo interessa interpretar o conteúdo das fontes históricas analisadas sobre guerras de caráter civil e militar nas quais os guaranis se envolveram durante o século XIX, com o propósito de possibilitar novas reflexões sobre a importância de seu papel histórico. Pistas sobre sua participação na batalha de Tacuarembó, na guerra dos Farrapos e na guerra do Paraguai suscitam novos questionamentos. Por e pelo quê índios guaranis lutaram? Qual a importância de sua atuação nas guerras provinciais? As respostas para essas perguntas são difíceis de aquinhoar. O certo é que o papel dos índios nas guerras ocorridas no período oitocentista necessita ser repensado. A partir dos indícios encontrados em tipos de fontes

${ }^{214}$ ALADRÉN, Gabriel. Liberdades negras nas paragens do sul: alforria e inserção social de libertos em Porto Alegre, 1800-1835. Rio de Janeiro: Editora FGV, 2009. FLORES, Moacyr. Negros na Revolução Farroupilha. Porto Alegre: Edições EST, 2004.

${ }^{215}$ DOURADO, Maria Teresa Garritano. "Tropas femininas em marcha". Revista Nossa História. Rio de Janeiro: Biblioteca Nacional, ano 2, n. 13, Nov. 2004, p. 18-23.

${ }^{216}$ GARCIA, Elisa F. "De inimigos a aliados: como parte dos missioneiros repensou o seu passado de conflitos com os portugueses no contexto das tentativas de demarcação do Tratado de Madri”, in Anais de História de Além-mar, vol VIII, 2007, p.123-137; NEUMANN, Eduardo Santos. "Episódios de rebelião na fronteira: a guerra guaranítica (1752-1756)", in GRIJÓ, Luis Alberto; NEUMANN, Eduardo Santos (org.). Continente em armas: uma história da guerra no sul do Brasil. Rio de Janeiro, Apicuri, 2010, p. 21-44.

${ }^{217}$ Para um panorama sobre definições, relações e problemas de natureza etnohistórica ver ROJAS, José Luis de. La etnohistória de América: los indígenas, protagonistas de su historia. [Seleccionado por Guillermo Wilde]. Buenos Aires, SB, 2008. 
variadas, este capítulo demonstra que suas atuações nos referidos eventos não têm sido devidamente dimensionadas. Nesse sentido, analisar as razões e as maneiras pelas quais se deram as ações dos índios de São Nicolau do Rio Pardo nas guerras provinciais é importante não só porque o aldeamento foi um espaço fundamental para os guaranis de toda a Província, mas por permitir reflexões sobre aspectos dos quais eles estiveram afastados durante um longo período nos discursos historiográficos: sua ação política, sua inserção em jogos de poder, sua atuação no comércio e na economia, e através disso, o exercício de um certo controle sobre suas histórias. Ponto importante a ser destacado é que o aldeamento ocupou posições fronteiriças durante conflitos bélicos. A batalha de Tacuarembó, quando houve a derrota de José Gervasio Artigas ${ }^{218}$ em 1820, “marcou o distanciamento político da Banda Oriental do restante das antigas províncias do antigo Vice-Reino do Rio da Prata" 219 . Durante a guerra dos Farrapos, a região de Rio Pardo se apresentava como um limite defendido e resguardado pelo governo imperial frente aos ataques dos farrapos. Quando houve a guerra do Paraguai, a Província de São Pedro também representava uma fronteira entre o Brasil e esta outra nação. Tudo isso remete à noção de fronteira como um espaço de transição que não é dado a priori, mas construído no tempo e no espaço pelos homens, incluindo aí as fronteiras políticas e culturais transformadas por eles mediante situações de contato. Assim, levar em conta situações fronteiriças permite perceber diferenças existentes entre pessoas que se encontravam entre um lado e outro desses limites. Isso é útil para o entendimento de que histórias indígenas, com toda a carga cultural, política, econômica e social que possuem, fizeram parte dos rumos que a história do Brasil tomou e vice-versa. Analisando o conceito histórico de fronteira, o antropólogo Lawrence Douglas Taylor Hansen, pondera que quando se trata de situações de contato podem existir várias fronteiras em um mesmo país. Este é o caso da história dos Estados Unidos ${ }^{220}$ :

\footnotetext{
${ }^{218}$ Artigas foi considerado um caudilho oriental, cujo projeto político entendia que cada comunidade com representação política devia exercer sua soberania particular. PRADO, Fabrício. "A presença luso-brasileira no Rio da Prata e o período cisplatino" in GRIJÓ, Luis Alberto; NEUMANN, Eduardo Santos (org.). Continente em armas: uma história da guerra no sul do Brasil. Rio de Janeiro, Apicuri, 2010, p. 82.

${ }^{219}$ IDEM. p. 84.

${ }^{220}$ HANSEN, Lawrence Douglas Taylor. "El concepto histórico de frontera", in AGUILERA, Miguel Olmos (coord). Antropología de las fronteras: alteridad, historia e identidad más allá de la línea. Ciudad de México, Miguel Angél Porrúa, 2007, p. 255-256.
} 
En realidad, había otros muchos casos de contactos entre grupos en esta denominada situación 'franteriza' global. Los colonos blancos no encontraron 'indios' en su movimiento hacia el oeste, sino cherokes, apaches, comanches, sioux y otros pueblos indigenas, cada uno de los cuales en algunos sentidos se distinguía dos demás. (...) De hecho, al estudiar la historia de la frontera en Estados Unidos hay que referirse necesariamente a las características comunes que pueden ser detectadas en todas las situaciones de contacto que han ocurrido a lo largo de la historia de esta entidad.

Ao longo da história da fronteira do Brasil também houve distintas situações de contato. Na Província de São Pedro tais situações envolveram participações de índios em guerras. $\mathrm{O}$ estudo dessas dinâmicas traz à tona a existência de transformações significativas em sua organização social. Nesse sentido, a estrutura social e a natureza das guerras indígenas foram abordadas em alguns trabalhos antropológicos muito importantes ${ }^{221}$. Não é preciso enfocar aqui detalhes sobre os apontamentos feitos nesses estudos, cujos temas e propósitos variados contribuíram para o enriquecimento da etnologia e mesmo da história dos índios ${ }^{222}$. Basta mencionar que, de modo geral e abreviado, alguns deles vêem na guerra o motor da máquina social indígena, um instrumento de captação da diferença através de atos entendidos como predatórios da alteridade, capazes de incorporar o que lhes é externo e de gerar, dessa forma, relações de reciprocidade e de socialidade ${ }^{223}$. No entanto, as participações dos guaranis nas guerras provinciais demonstram a extrema reversibilidade e flexibilidade cultural que fez parte dos processos de adaptação e reestruturações que eles experimentaram durante o período imperial.

${ }^{221}$ Como exemplo FERNANDES, Florestan. Organização social dos Tupinambá. São Paulo, Difusão Européia do Livro, 1963; CLASTRES, Pierre. A sociedade contra o Estado: pesquisas de antropologia política. São Paulo, Cosac \& Naify, 2003; VIVEIROS DE CASTRO, Eduardo. A inconstância da alma selvagem - e outros ensaios de antropologia. São Paulo, Cosac \& Naify, 2002.

${ }^{222}$ FAUSTO, Carlos. Inimigos fiéis: História, Guerra e Xamanismo na Amazônia. São Paulo, Editora da Universidade de São Paulo, 2001. _. Se Deus fosse Jaguar: canibalismo e cristianismo entre os Guarani (XVI a XX). Mana, 11:2, 2005, p. 385-418.

${ }^{223}$ Segundo Eduardo Viveiros de Castro, "A agressão guerreira ameríndia revela-se então um processo de 'transformação ritual do Eu', para emprestarmos de Simon Harrison sua profunda definição da guerra melanésia. Ela nos conduz ao outro lado do pensamento selvagem, à face oculta da lua estruturalista: antes que ao totemismo, ao simbolismo e à metáfora, ela remete ao sacrifício, ao animismo e à metonímia. Se a razão totêmica (se toda razão não o é) opera através da articulação reversível entre séries que permanecem distintas das relações a ligarem-nas, as figuras sacrificiais, tal essa do devir matador-vítima, visam ao contrário a transformação de uma série em outra, operação 'absoluta ou extrema' (Lévi-Strauss 1962-b: 298) que se move no elemento sombrio da continuidade, da indiscernibilidade e da irreversibilidade". VIVEIROS DE CASTRO, Eduardo. Op. Cit. p. 293-294. 
Outra consideração importante foi feita pelo antropólogo Guillermo Wilde. Segundo ele, as constantes mudanças ocorridas nos comportamentos políticos e nos processos de identificação sociocultural vividos pelos guaranis foram classificadas sob o rótulo das categorias étnicas: "La etnologia del siglo XX instalo el supuesto de una homogeneidad étnica y cultural de los guaraníes" ${ }^{224}$. Essas homogeneizações etnológicas podem acabar contribuindo para petrificar imagens, congelando-as como estátuas do tempo, obliterando as mudanças nos atos dos índios e relegando seu papel de agentes históricos à estaticidade supostamente inerente aos seus modos de ser e agir. Por outro lado, reconhecer as alianças que as sociedades indígenas estabeleceram ao longo do tempo, inclusive aquelas feitas durante as guerras provinciais, contribui para romper com a lógica da aculturação, à medida que torna evidente a diversidade de contextos e personagens históricas envolvidas nos conflitos bélicos, assim como seus modos próprios de negociar e trocar bens materiais e simbólicos. É importante não naturalizar conceitos, categorias e noções. Ao contrário, é preciso buscar enxergar as sociedades indígenas pelas 'próprias lógicas'. Muitas vezes, suas ações nas guerras foram interpretadas como uma espécie de ato heróico e cristalizadas através de figuras como a de Sepé Tiarajú, guarani-missioneiro considerado herói da guerra guaranítica, e Andrés Artigas (Andresito), aliado e afilhado de Artigas nas disputas pela hegemonia na região do rio da Prata. Dessa forma, se estabelece uma espécie de padrão comportamental para todos os demais guaranis. Pautadas unicamente através de atos de resistência, essas visões sobre guerras em que os índios se envolveram acabam sendo entendidas como bravuras que servem de emblema à sua 'recalcitrância', mas que no final, não impedem seu desaparecimento ${ }^{225}$ :

Nas gemas do nosso folclore, nas nossas lendas do campo, em todas as tradições da vida gaúcha, ficou a lembrança do índio missioneiro. Carinhosa expressão de amor, nas bravatas heróicas do pago, a china, a chinoca, ainda vive na sua beleza imortal de flor da estância.

O historiador Aurélio Porto se refere à história das missões orientais do Uruguai como se os guarani-missioneiros e suas ações tivessem tido um fim ao término do século

\footnotetext{
${ }^{224}$ WILDE, Guillermo. Op. Cit. 2009, p. 31.

225 PORTO, Aurélio. História das Missões Orientais do Uruguai. Porto Alegre: Livraria Selbach, 1943, p. 430.
} 
XVIII, restando deles apenas lembranças daquilo que, em sua concepção, não constitui fatos históricos sobre atos indígenas, mas elementos folclóricos e lendários sobre "as chusmas incultas de pobres índios" ${ }^{226}$. Todavia, elementos históricos podem perpassar tradições consideradas lendárias e folclóricas ${ }^{227}$. Ao articular informações encontradas em documentos do século XIX, não parece que os índios guaranis tenham se envolvido exatamente em 'bravatas', mas participado ativamente de conflitos bélicos. Suas experiências não estiveram restritas ao passado setencentista, como escreveu o historiador; ao contrário, constituíram experiências relevantes para a história do Brasil durante o Oitocentos.

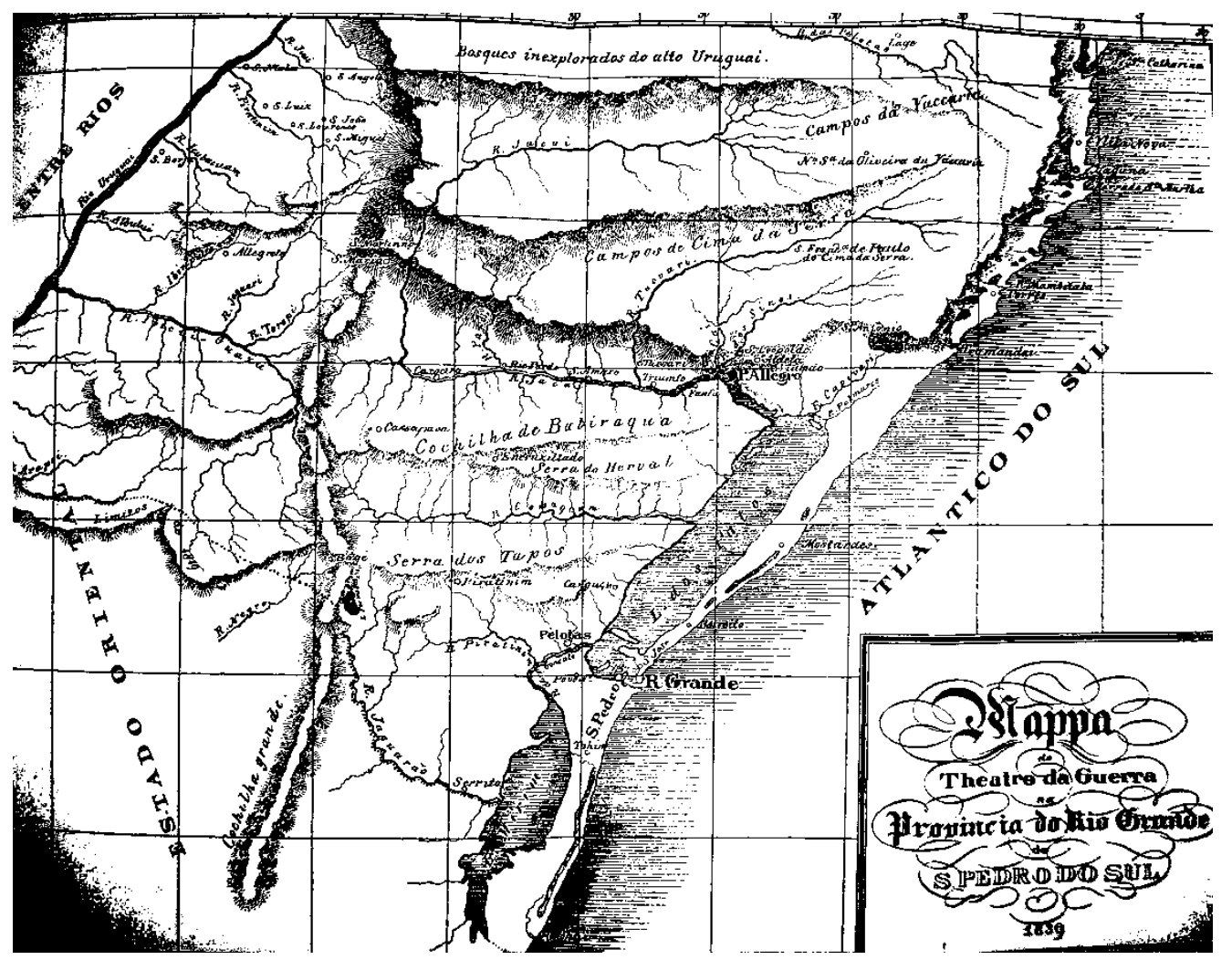

IMAGEM 10 - Mapa do Teatro da Guerra na Província do Rio Grande de São Pedro do Sul, 1839.

Fonte: DREYS, Nicolau. Notícia descritiva da Província do Rio Grande de São Pedro do Sul. Porto Alegre. IEL, 1961.

\footnotetext{
${ }^{226}$ PORTO, Aurélio. Op. Cit., p. 14.

227 DARNTON, Robert. O Grande Massacre dos Gatos, e outros episódios da história cultural francesa. Tradução de Sônia Coutinho. Rio de Janeiro. Graal, 2010, [1986]. Darnton nos mostra que nas tradições populares francesas dos séculos XVII e XVIII, os elementos tidos como folclóricos eram considerados meramente culturais, quando na verdade traziam consigo muitos aspectos históricos da cultura popular francesa e alemã.
} 


\section{2 - GUARANIS EM ARMAS}

As estreitas relações existentes entre São Nicolau do Rio Pardo e as atividades militares são evidenciadas nos documentos históricos. As reformas na casa de guerra e na prisão do aldeamento, por exemplo, foram constantemente solicitadas por autoridades provinciais, indicando que aquele espaço e a estrutura militar que ele possuía eram percebidos como aspectos fundamentais para as políticas indigenistas e para as políticas militares da Província: "Acha-se em mau estado a casa que serve de quartel e prisão no aldeamento de São Nicolau e que seus reparos tinham sido orçados em 200\$000, V. Ex. autorizou essa despesa (...)" ${ }^{228}$. Até mesmo o encarregado da estatística parecia preocupado com o poder de fogo do inimigo e alertou o presidente da Província Salvador José Maciel sobre isso ${ }^{229}$ :

Dizem que nosso Exército se acha em São Lourenço e se julga vir para esta vila. $O$ restante da ponte de Rio Pardo, espero fique concluída até terça-feira. Visto que o Exército se acha tão próximo, e ali nomeei alguns oficiais engenheiros, receio dar princípio ao outro no lugar deste forte velho em que $V$. Ex. novamente me ordena, e lhe rogo queira então remeter as ordens necessárias, pois que receio algumas contratações. Igualmente lembro a V. Ex. Quando a este construído no morro do Moinho, poderá o fogo do inimigo causar grande dano a esta vila.

A casa de guerra, que servia de quartel, o forte e a prisão no aldeamento continuaram sendo importantes e os pedidos para a reforma dos mesmos foram mais tarde atendidos pelo presidente da Província ${ }^{230}$. A presença e o trânsito do exército entre povos das Missões e São Nicolau do Rio Pardo acusam a participação dos guaranis em atividades militares. Durante os eventos bélicos, a prisão e a casa de guerra funcionaram como um importante entreposto militar por onde muitas pessoas passaram. Bens materiais e simbólicos circularam. Em apontamentos sobre presídios, elite militar e soldados na região da Baixa Califórnia, Lucila del Carmen León Velazco tece considerações importantes. A

\footnotetext{
${ }^{228}$ AHRS, Fundo Indígenas, Aldeia de São Nicolau, Diversos, maço 2, anexo sem data.

${ }^{229}$ AHRS, Fundo Estatística, Documentação avulsa, Correspondência ativa do encarregado da estatística, José Pedro Cezar, maço 3, 3 de março de 1827. "Acuso o recebimento do oficio de V. Senhoria com data de 13 do corrente no qual me diz que para poder satisfazer o que pedira o Exmo. Sr. Presidente da Província respeito a obra da casa de guerra e da prisão de São Nicolau em virtude ao meu oficio de 28 de junho (...)".

${ }^{230}$ AHRS, Fundo Indígenas, Correspondência ativa José Joaquim da Fonseca e Souza Pinto; José Joaquim de Andrade Neves. Aldeia de São Nicolau, maço 2, agosto de 1848.
} 
historiadora, em seu estudo sobre as mudanças na instituição presidiária desde a etapa jesuítica até a dominicana, bem como atividades de soldados e sua relação com os indígenas e missionários faz referência ao fato de que "la función del presido, y con ello las tareas de los soldados, fue modificando-se de acuerdo con el momento, el contexto político y la región particular en que se establecia (...)". Tais modificações e junto com elas as mudanças na "distribuición de la fuerza militar muestra el peso de las actividades de los soldados para cada región" ${ }^{\text {231 }}$. Assim, não foram somente a estrutura física e a localização de São Nicolau do Rio Pardo os únicos aspectos a serem valorizados pelas autoridades provinciais, mas o desempenho dos índios nas atividades militares. Certamente, eles não participaram massivamente dos conflitos abordados neste capítulo, tampouco tiveram as mesmas motivações e objetivos. Entretanto, a documentação analisada revela que os serviços militares prestados por eles foram valorizados em alguns momentos, assim como a posição estratégica de São Nicolau do Rio Pardo.

A presença de soldados guaranis foi evidenciada em relatos de cronistas e viajantes. A obra de Auguste Saint-Hilaire é um exemplo. O conhecido cientista francês viajou por regiões da Argentina, Brasil e Uruguai entre os anos de 1820 e 1821 . Ele presenciou o contexto em que se deu a batalha de Tacuarembó e relatou suas impressões. Seus apontamentos são tendenciosos e marcados pelo etnocentrismo, assim como os documentos escritos por outros viajantes e também por oficiais do governo. O que os diferencia são os contextos e os propósitos para os quais foram produzidos. Ainda assim, é impressionante a maneira como Saint-Hilaire descreveu - ao longo de todo o relato - a presença marcante e intensa dos guaranis neste cenário, bem como suas relações mantidas em função do serviço militar com órgãos governamentais, particulares e outras alteridades como os índios charruas e os minuanos. Percorrendo campos, estâncias e aldeamentos onde havia soldados, ele se mostrou surpreso ao verificar o 'estado de guerra' em que viviam seus moradores. Considerou alguns locais "uma praça de guerra", como no caso de São Borja.

\footnotetext{
${ }^{231}$ LEÓN VELAZCO, Lucila del Carmen. "Mujeres y soldados en la historia misional de Baja California", in AGUILERA, Miguel Olmos (coord). Antropología de las fronteras: alteridad, historia e identidad más allá de la línea. Ciudad de México, Miguel Angél Porrúa, 2007, p. 271-272. Os dois últimos trechos foram retirados desse texto.
} 
Testemunhando a presença de índios guaranis nesses lugares e seu envolvimento com o serviço militar, ele escreveu ${ }^{232}$ :

É extremamente necessário diminuir o aspecto militar dessa província, se não quiserem destruí-la toda. A mocidade guarani está em armas; não se cultivam as terras das aldeias; os jovens hoje estranhos aos trabalhos de campo, já não aprendem ofício algum. Os brancos, sempre empregados no serviço militar, não podem pensar em substituílos.

Quanto às imprecisões do relato, não se pode dizer que os índios não tenham aprendido ofício algum. Havia lugares onde guaranis aprendiam artes e outros ofícios, como vimos no capítulo 3. O suposto abandono das roças e a ausência da mão-de-obra dos índios nas atividades agrícolas também não podem ser atribuídos exclusivamente à sua atuação no exército, afinal, a conjuntura gerada pelas guerras e a preocupação do governo com as mesmas muitas vezes fizeram com que as necessidades dos índios aldeados fossem postas em segundo plano. Mas, é verdade que fontes históricas distintas, como as analisadas neste capítulo, informam sobre a participação de guaranis nos conflitos bélicos. Os índios não ignoravam a importância dada pelas autoridades provinciais aos conflitos e a atenção dispensada àqueles que deles participavam.

Em 1820, Saint-Hilaire deu notícias sobre o envolvimento de guaranis vindos do Paraguai, de Entre-Rios e da Província de São Pedro na batalha de Tacuarembó. Esse conflito se deu entre os interesses luso-brasileiros e as Províncias Unidas do Rio da Prata, após o exército português ter avançado em território cisplatino (atual Uruguai) e encontrado resistência por parte de José Gervasio Artigas. Vale lembrar que tal conflito foi precedido pelo desenrolar de acordos e desacordos em função de crises da monarquia espanhola e a chamada Província Oriental desde 1808, quando Portugal foi invadido e a corte real transferida para o Brasil. A Espanha também havia sido invadida por tropas napoleônicas. Essas conjunturas históricas e os problemas gerados por elas cruzaram o oceano, tiveram seus efeitos na região platina e "em 1811, a Banda Oriental foi sacudida pelo levante de tropas na campanha de José Artigas e seus aliados" ${ }^{233}$. O exército artiguista foi derrotado.

\footnotetext{
${ }^{232}$ SAINT-HILAIRE, Auguste. Op. Cit. p. 339-340.

${ }^{233}$ PRADO, Fabrício. Op. Cit. p. 79.
} 
É interessante pensar nas atuações dos índios tendo em vista todas essas mudanças políticas. Em certa medida, tais atuações e mudanças podem ter contribuído para garantir ou ameaçar sua sobrevivência como uma coletividade. Nesse emaranhado de acontecimentos, chama a atenção que o reconhecimento dos serviços prestados por eles tenha levado em conta a distinção étnica e afirmado a existência de elementos que naquela conjuntura compuseram traços da identidade guarani aos olhos dos outros. O discurso de Saint-Hilaire oferece pistas a esse respeito ${ }^{234}$ :

O que os torna talhados à vida militar é a espécie de resignação com que suportam a fome, as fadigas e as intempéries das estações. Eles se distinguiram em diversas circunstâncias. Portugal lhes deve grande parte dos sucessos obtidos na batalha de Tacuarembó. Reconheceu que eram bem aproveitados nas manobras de artilharia, mas nada sabendo combinar, foi necessário misturá-los com os brancos, para lhes seguir os exemplos.

Para Saint-Hilaire, a atuação diferenciada dos soldados indígenas na guerra se devia ao fato de serem guaranis, embora reconhecesse a mistura entre eles e os brancos. O general que governava a capitania de São Pedro na época, o conde da Figueira, ficou famoso por vencer a batalha contra o caudilho Artigas. De acordo com o relato, o viajante francês havia recebido notícias da batalha por parte do próprio conde, com quem esteve durante sua visita a Porto Alegre. Segundo o conde, Artigas teria arregimentado grande número de índios guaranis para lutar fazendo-os crer que a fronteira estaria desguarnecida de tropas, que não encontrariam resistência e poderiam se apoderar do gado das estâncias portuguesas. Vários prisioneiros de guerra, com quem Saint-Hilaire estivera, disseram ser paraguaios e que trabalhavam como peões na Província de Entre-Rios, obrigados por Artigas a pegar em armas. O viajante emitiu um juízo sobre os prisioneiros e os descreveu fisicamente, mencionando partes de seus corpos, tarefa considerada científica para os padrões da época ${ }^{235}$ :

\footnotetext{
${ }^{234}$ SAINT-HILAIRE, Auguste. Op. Cit. p. 338-339.

${ }^{235}$ IDEM, p. 53.
} 
É muito provável que essa gente esteja mentindo e que tenha acompanhado seu chefe na esperança de praticarem a pilhagem. Como quer que seja, os prisioneiros guaranis são, em geral, homens de baixa estatura, mas parecendo pequenos, em razão do corpo apresentar desmesurada largura, tem pescoço muito curto, cabeça grande e alongada, cara muito larga, olhos compridos, estreitos e pouco divergentes; sobrancelhas negras, bastas e arqueadas, nariz comprido e grosso, boca muito grande; cabelos pretos e lisos; pele roxo-amarelada e as nádegas volumosas.

Segundo ele, a forma alongada da cabeça diferenciava os guaranis das outras 'tribos' que ele havia conhecido ${ }^{236}$. Chamou-lhe a atenção também os uniformes que os soldados usavam. Muitos deles tinham na cintura "um cobertor listrado, formando uma espécie de saiote (saia, chiripá). A maior parte conservava os cabelos comprimidos e trançados; pela fisionomia e grossura dos membros lembram os cossacos, como também os recordam pelos costumes" ${ }^{237}$. Nota-se que vários elementos foram usados para reconhecer os índios como soldados e como guaranis. A comparação com outros povos que guerrearam foi um deles. Os cossacos foram um 'povo' nativo das estepes da região da Ucrânia e do sul da Rússia. Famosos pela sua coragem, bravura, força e capacidades militares, especialmente na cavalaria, também se destacaram por sua 'auto-suficiência' durante as batalhas $^{238}$. Essas analogias e comparações feitas por Saint-Hilaire trazem consigo noções que são bastante amplas. Elas misturam saberes e visões de mundo generalizados. Estendem-se desde entendimentos sobre resistências e habilidades humanas na guerra até a descrição de traços físicos dos índios. Em meio a essas informações que fizeram parte da construção do conhecimento científico sobre os índios naquela época, importa ressaltar que, se o envolvimento em guerras pode ser considerado como um modo de reconfiguração e reprodução próprio de certas culturas indígenas, também pode ser considerado como ações que fizeram parte da construção de suas histórias. De acordo com Guillaume Boccara ${ }^{239}$ :

\footnotetext{
${ }^{236}$ Sobre alguns trabalhos científicos realizados sobre os índios ver MONTEIRO, John Manuel. Tupis, tapuias e historiadores. Estudos de história indígena e do indigenismo. Tese apresentada para o concurso de Livre Docência em Antropologia na Universidade Estadual de Campinas, Campinas, 2001. Capítulo 8: As "Raças” Indígenas no Pensamento Brasileiro, p. 140-179.

237 SAINT-HILAIRE, Auguste. Op. Cit. p. 53.

238 DOUGAN, Andy. Futebol \& guerra: resistência, triunfo e tragédia do Dínamo na Kiev ocupada pelos nazistas. Rio de Janeiro, Ed. Jorge Zahar, 2004 (Tradução autorizada pela primeira edição inglesa publicada em 2001 por Fourth Estate, uma divisão da HarperCollins Publishers, de Londres, Inglaterra). p. 22-23.

${ }^{239}$ BOCCARA, Guillaume. Op. Cit. 2005, p. 37.
} 
Hoy sabemos que la desaparición progresiva de las guerras de incorporación y de las diversas formas de canibalismo ritual fue concomitante con la aparición de formas de definición identitaria radicalmente nuevas así como la conexión de las economías indígenas a las redes comerciales capitalistas.

As guerras em que os índios se envolveram também estiveram marcadas por divisões territoriais e fronteiriças que iam sendo estabelecidas entre os governos de nações vizinhas, mediante acordos diplomáticos e batalhas. Os soldados liderados por Artigas e pelo conde da Figueira eram, em parte, guaranis. No relato de Saint-Hilaire, ambas as tropas "montam com uma destreza de que não há exemplo na Europa; transportam-se com incrível rapidez a grandes distâncias", são "excelentes para uma luta corpo a corpo", não eram "inferiores na arte de atravessar rios a nado, pois conheciam, igualmente, palmo a palmo a região". Os soldados de ambos os lados "adotavam costumes quase idênticos aos dos índios". No entanto, a vitória da tropa liderada pelo Conde da Figueira "ficou desvalorizada quando se soube o tipo de inimigo que os portugueses enfrentaram. Quase todos, míseros índios (...)". E o êxito das tropas 'portuguesas', se deu "finalmente, pela ânsia de defenderem suas famílias e propriedades" ${ }^{240}$. Podemos notar que as identidades indígenas e o processo de suas construções eram permeados por questões políticas e militares, e se misturavam com aspectos sociais e costumes culturais nos escritos de SaintHilaire. Este episódio histórico ocorrido em Tacuarembó nos leva a refletir sobre as ações que remetiam aos costumes guaranis na guerra. Eles parecem ter sido praticadas por ambas as tropas. Do lado da fronteira portuguesa, porém, os guaranis saíram vitoriosos. Seu prestígio e fama guerreira corriam os corredores do palácio do governo em Porto Alegre, onde Saint-Hilaire conversou com o conde da Figueira. Entretanto, os atributos que os enalteciam e às suas façanhas eram os mesmos que as desmereciam quando era posto em questão o 'tipo' do seu inimigo: 'outros míseros índios'. Do lado da fronteira platina, os guaranis saíram derrotados e foram presos em terras inimigas. Suas habilidades foram postas em paridade com as de seus inimigos, mas acabaram por desmerecer seus esforços na derrota.

${ }^{240}$ Os trechos deste parágrafo foram retirados de SAINT-HILAIRE. Op. Cit. p. 53. 
Através deste relato, pode-se notar que as formas de atuação dos índios guaranis nas guerras nem sempre eram coincidentes. Quero com isso, sugerir que o fato de serem guaranis certamente não condicionou suas participações no conflito a um modo único de atuar. O certo é que participaram ativamente do conflito e ocuparam importantes posições sociais naquele contexto histórico ao interagirem com outros sujeitos históricos. Nesse sentido, Guillaume Boccara articulou o macro e o micro através de um jogo de escalas que também envolveu complexidades fronteiriças ${ }^{241}$ :

A nivel macro, una política de imperio y de contrahegemonía que delimita y define grupos o etnias; a nivel micro, una sociedade fluida en la cual existe una gran intimidad y fuertes vínculos entre indígenas, mestizos y criollos.

De fato, o encontro e o desencontro de interesses políticos, de costumes culturais e demandas sociais foram vividos por todas essas personagens. Em algumas ocasiões, acontecimentos que remetiam à atuação dos índios nas guerras foram lembrados e invocados de maneiras e por motivos muito variados. As habilidades dos guaranis na batalha de Tacuarembó, por exemplo, fizeram com que Saint-Hilaire se lembrasse dos soldados cossacos. É um olhar europeu que busca correspondências e embora ele tenha comparado os guaranis aos cossacos enquanto descrevia aos índios fisicamente, as semelhanças se dão mais pelos seus atos do que pela sua aparência. E não se trata, aqui, de uma simples dicotomia entre aparência e essência, pois a aproximação feita entre eles se deu a partir do modo de agir dos soldados quando praticavam a guerra. Vale a pena enfatizar que tanto os guaranis que vieram do Paraguai e de Entre-Rios e se encontravam presos na Província, quanto aqueles que estavam em liberdade pelos lugares onde SaintHilaire passou lhe trouxeram à lembrança a imagem dos soldados russos. Ambos se destacaram ao atuar nos conflitos bélicos. Mas, para o viajante, também havia elementos capazes de diferenciar os guaranis dos cossacos, entre eles a música como elemento cultural e histórico de seus costumes ${ }^{242}$ :

\footnotetext{
${ }^{241}$ BOCCARA, Guillaume. Op. Cit. 2005, p. 47.

${ }^{242}$ SAINT-HILAIRE, p. 330.
} 
Os soldados guaranis tem muito boa aparência. Geralmente mais sensíveis que os homens de nossa raça às modulações da música, indicam o compasso, quando marcham, por uma cadência bem marcada. Em armas se parecem singularmente aos cossacos regulares, e o Conde da Figueira, admirado por essa semelhança, melhorou-a ainda dandolhes uniforme azul com golas vermelhas, mais ou menos talhados do feitio dos cossacos.

A semelhança parecia ser importante para autoridades políticas e rendeu aos índios certo prestígio entre elas. Às habilidades indígenas na guerra se juntou o apreço pela música, um costume guarani que parece ter servido para identifica-los e diferencia-los nas práticas militares $^{243}$ :

Ontem à tarde, após o sinal de recolher, a banda do regimento dos guaranis veio ao pátio do convento e, na presença do coronel, executou a marcha da corporação com gosto e precisão extremas.

Saint-Hilaire também descreveu a performance de soldados e lanceiros guaranis vindos de Rio Pardo, São Borja e acampamentos militares como Salto Grande e Campo de Belém. Em São Borja, admirou-se com a igreja e a limpeza com que era mantida, surpreendeu-se "quando imaginava que todas as aldeias das Missões e as moradias nelas construídas são obras de um povo selvagem, orientado pelos religiosos”. Algumas vezes, irritou-se com a presença da música em meio às questões militares e políticas. Apesar do costume etnocêntrico que marcam as palavras de Saint-Hilaire, elas revelam olhares sobre os costumes e as experiências históricas dos índios ${ }^{244}$ :

Esta manhã estava eu na missa e, enquanto o padre a celebrava, as crianças entoaram alguns cânticos em português, com vozes muito agradáveis e afinadas. Os jesuítas, como os antigos legisladores, se serviam da música para suavizar os costumes dos guaranis e para cativálos. Tal expediente lhes deu bons resultados, porque essa gente demonstra pela arte musical grandes pendores. Como os índios não ouviam o som dos instrumentos, pelos quais eram apaixonados, senão nas cerimônias religiosas, logo adotaram a música como parte essencial do culto divino. Ela lhes fez amar as cerimônias religiosas, tornando-os

\footnotetext{
${ }^{243}$ IDEM, 331.

${ }^{244}$ IDEM, p. 270-331. Os grifos são meus.
} 
cristãos tanto quanto podiam ser. Após a expulsão dos jesuítas, o gosto pelos instrumentos persistiu entre os guaranis, por assim dizer sem mestres; continuaram a aprender a música que talvez tenha contribuído tanto para fazê-los soldados, como outrora cristãos.

Saint-Hilaire relacionou a presença da música em acampamentos militares ao modo de ser dos índios. Vinculou o apreço que tinham por ela à experiência que haviam tido com os jesuítas. Identificou as práticas musicais dos índios como tributárias de sua religiosidade cristã. O que o cientista francês não escreveu, mas é possível inferir através do seu relato é que ao serem transformados como sujeitos históricos pelas ações, pensamentos e sentimentos que viveram no convívio com outras pessoas, os índios também puderam modificá-las e aos conflitos bélicos nos quais uns e outros atuaram. No passado oitocentista, as guerras fizeram parte das experiências históricas de muitos guaranis e suas atuações nas mesmas construíram esse processo histórico e marcaram permanentemente a reconfiguração de suas identidades étnicas, como veremos a seguir.

\section{3 - "O PESO DA ESPADA OU DA LANÇA"}

Em 1830, a região da campanha no Estado Oriental já contava com a presença de estancieiros luso-brasileiros que eram proprietários de terras naquele território, do qual a economia do charque rio-grandense dependia. O controle da entrada e saída de gado, de um lado para outro da fronteira estava sob o comando daqueles que ficariam conhecidos como 'farrapos'. Entre outros motivos, a disputa pelo controle de terras e pela garantia da manutenção da economia charqueadora daria início à guerra civil de caráter republicano contra o império do Brasil. Mas os estancieiros sul-rio-grandenses e as lideranças farroupilhas não tinham como único adversário o império brasileiro. Terras e bens materiais eram confiscados em suas estâncias no Estado Oriental por parte de forças militares de caudilhos. A guerra dos Farrapos se iniciou em 1835 e só terminou uma década mais tarde. Mesmo assim foi preciso contar ${ }^{245}$ :

\footnotetext{
${ }^{245}$ SOUZA, Susana B.; PRADO, Fabrício. "Brasileiros na fronteira uruguaia: economia e política no século XIX”, in GRIJÓ, Luiz Alberto; KÜHN, Fábio; GUAZELLI, César Augusto Barcellos; NEUMANN, Eduardo Santos (orgs.). Capítulos de Historia do Rio Grande do Sul. Porto Alegre, EDUFRGS, 2004, p. 126.
} 
(...) com a participação imperial e o atendimento parcial das reivindicações farroupilhas, encontrou o Uruguai enfrentando uma guerra civil com dimensões internacionais que assolava o território do país, desorganizando a campanha.

A guerra dos Farrapos foi muitas vezes tida como símbolo da belicosidade e das proezas sul-rio-grandenses, "cuja história está cheia desses prodígios" 246, mas a participação dos índios nela parece ter ficado um pouco apagada. Spencer Leitman, ao analisar as raízes sócio-econômicas da guerra dos Farrapos ponderou que "tanto espanhóis quanto portugueses, tentaram conquistar mais terra, mais gado, e a lealdade das tribos indígenas, numa luta que seus descendentes continuaram no século XIX”. ${ }^{247}$ Reunindo informações extraídas dos escritos de José Feliciano Martins Pinheiro, o visconde de Porto Alegre, e cartas do presidente da província Salvador José Maciel, Leitmann colocou o seguinte ${ }^{248}$ :

Depois da independência o remanescente indígena das Missões foi levado para as estâncias e charqueadas, ou para os batalhões da milícia. Os guaranis tinham recebido uma atenção especial dos portugueses nos tempos coloniais e os rio-grandenses continuaram essa tradição.

Certamente os guaranis continuaram sendo importantes personagens históricas ao longo do século XIX, assim como tinham sido no século XVIII, mas isso não se deve simplesmente à atenção dispensada a eles por parte dos portugueses, espanhóis e lusobrasileiros, mas devido às suas próprias ações e escolhas. A participação em atividades militares não era uma 'novidade' da época oitocentista. Segundo Guillermo Wilde ${ }^{249}$ :

\footnotetext{
${ }^{246}$ AHRS, Anais do Arquivo Histórico do Rio Grande do Sul, v. 5, p. 53.

${ }^{247}$ LEITMAN, Spencer. Raízes sócio-econômicas da guerra dos Farrapos. Rio de Janeiro, Graal, 1979, p.16.

${ }^{248}$ IDEM, p. 89.

${ }^{249}$ WILDE, Guillermo. Religión y poder en las misiones de guaraníes. Buenos Aires: SB, 2009. p. 165.
} 
Ya desde siglo XVII la situación fronteriza de las misiones había hecho de la actividad militar un aspecto constitutivo de la identidad guaraní. En un primer momento las milicias defendian a los pueblos de los ataques paulistas. Más tarde contribuían a la defensa de los territorios del monarca católico. Durante el siglo XVIII, el control de los circuitos comerciales y la definición de límites fronterizos se convertieron en prioridades para la afimación del poder de las coronas ibéricas.

Durante o século XIX muitos guaranis continuaram participando das atividades militares, mas os interesses, as dificuldades e as maneiras através das quais se inseriam na estrutura do serviço militar mudaram e isso continuou a ocasionar transformações em aspectos constitutivos da identidade guarani. Em 1841, o brigadeiro Juan Pablo dos Santos Barreto, comandante e chefe do exército de operações da Campanha do governo argentino, escreveu ao seu sucessor dando conta dos planos de guerra e dos serviços que havia realizado no Brasil a fim de combater os rebeldes da Guerra dos Farrapos. Segundo ele, soldados que lutaram ao lado do governo imperial do Brasil pareciam encontrar descanso e alguns poucos recursos em territórios ocupados por guaranis, como o rincão de São Vicente 250 .

Es urgente que el Ejército tome cuarteles de invierno para proverse y dar descanso a estas valientes tropas dignas de los actos más encomios. El mejor lugar es San Vicente, donde se puede descansar con seguridad los soldados y donde las cavalhadas que son casi inútiles sirve por lo menos para el servicio diario y la carne, que es difícil. Coronel Loureiro, comandante de la Tercera Brigada, con uno de sus cuerpos van a Corrientes comprar seis mil caballos.

Os soldados que atuaram contra as forças rebeldes eram dignos dos atos mais elogiosos, de acordo com o comandante do governo argentino. Outros relatórios e correspondências encaminhadas e recebidas por autoridades da Província também não deixam dúvidas sobre o quão importante foi a participação de índios guaranis na guerra dos Farrapos. Contraditoriamente, em alguns casos, essa participação não foi vista com bons olhos. Mesmo assim, muitos índios se mantiveram na prestação desses serviços. Em 1857,

250 AGN (Buenos Aires), Período Nacional, Sala X [Comando de Fronteiras (1810-1859)], Brasil, Correspondência com o governo (1816-1852), localização: 1-7-11. Quartel General de São Gabriel, 21 de junho de 1841. Os três últimos trechos foram retirados desta fonte. 
o comendador Patrício Correa da Câmara escreveu sobre São Nicolau do Rio Pardo para a presidência da Província ${ }^{251}$ :

Acha-se este aldeamento bastante atrasado. Existem ali 264 índios, sendo 112 do sexo masculino, e 132 do sexo feminino, a maior parte velhos e aleijados das guerras nesta Província e no estado Oriental, o diretor queixa-se de que os moços sejam todos recrutados pelo Exército no que não the acho muita justiça, porque eles são pouco afeiçoados ao trabalho.

O que parece ter sido um choque de interesses políticos e territoriais para o governo imperial e provincial pode não ter sido assim tão contraditório para as políticas indígenas. Embora sua atuação em atividades militares contribuísse para o esvaziamento do aldeamento e pudesse provocar até mesmo sua extinção, o recrutamento continuou a ocorrer. Pode ser que com a participação em guerras, os índios obtivessem mais benefícios do que em permanecer no aldeamento, que muitas vezes não recebia a devida atenção por parte dos políticos e religiosos. Apesar da tentativa desses últimos em demonstrar na documentação que cumpriam com as suas 'obrigações' é possível perceber nas entrelinhas que não era bem assim. Nem sempre os políticos se esforçavam para que o aldeamento fosse mantido. Logo, seu esvaziamento e extinção não se devem somente as ações dos índios. A opção dos guaranis em participar da guerra dos Farrapos oferece alguns indicativos a esse respeito. Um ano mais tarde, o padre e diretor de São Nicolau do Rio Pardo, José Joaquim da Fonseca e Souza Pinto, insistiu nos mesmos argumentos desacreditados pelo comendador numa carta enviada ao diretor geral dos índios ${ }^{252}$ :

Esta aldeia há muito que está lançada no esquecimento e a miséria nela é uma terrível verdade, seus povoadores são quase todos velhos $e$ crianças, encontrando-se dentre aqueles muitos servidores ao Estado, que por sê-lo, se inutilizaram por ocasião da guerra civil nesta Província.

\footnotetext{
251 AHPA. Relatório do Vice-Presidente da Província de São Pedro do Rio Grande do Sul, Patrício Correa da Câmara, na abertura da Assembléia Legislativa Provincial, 01 de outubro de 1857.

252 AHRS, Correspondência ativa José Joaquim da Fonseca e Souza Pinto; José Joaquim de Andrade Neves. Diretoria Geral dos Índios, maço 4, março de 1858.
} 
Por um lado, o comendador informava sobre a invalidez dos índios mais velhos em função das guerras civis e militares que houve na Província, atestando a prestação de serviços por parte dos mesmos, bem como sua 'utilidade' ao Estado. Por outro, insinuava que os jovens eram duplamente inúteis; primeiro, por não serem muito afeitos ao trabalho; segundo, por não poderem compor a povoação do aldeamento pelo fato de serem recrutados pelo Exército, ocasionando o esvaziamento do mesmo. Todavia, ao que parece, tanto os índios idosos quanto os jovens, haviam prestado ou estavam prestando valiosos serviços à Província de São Pedro. Há um ponto interessante presente nesse relatório sobre os índios mais jovens de São Nicolau. Segundo o comendador, eles não poderiam ser recrutados pelo Exército, pois não eram afeiçoados ao trabalho. Caso as pistas deixadas neste documento não tenham sido exageradamente marcadas pelas impressões preconceituosas de quem as deixou, ou seja, pela suposta inaptidão dos índios para o trabalho, talvez elas ofereçam indícios para pensar as estratégias indígenas acionadas naquele contexto. Para o historiador José Iran Ribeiro, nesse contexto, muitos indivíduos não tinham conhecimentos específicos sobre as atividades militares e serviam contra a vontade ${ }^{253}$. Se esses jovens, em alguns momentos puderam escolher entre prestar serviços militares ou não, significa que aqueles que não desertaram, possivelmente vislumbraram nessa opção oportunidades melhores do que aquelas oferecidas dentro do aldeamento. Contudo, conviver com os idosos e vislumbrar naquela condição de inválidos e esquecidos uma possibilidade do que poderia vir a ser o seu futuro, certamente não tornava a decisão de deixar o aldeamento mais fácil. Apesar de todos esses obstáculos, é fato que jovens e idosos guaranis participaram de guerras civis e militares.

O conteúdo de fontes como as supracitadas demonstra também a mobilidade espacial de alguns índios com as idas e vindas dos aldeamentos em virtude das excursões militares. Esse é um dos motivos pelos quais a maior parte da população de São Nicolau do Rio Pardo era composta por velhos, mulheres e crianças. É interessante observar tal mobilidade levando em conta que houve um número considerável de guaranis empregados em Corpos da Guarda Nacional, como veremos adiante. Assim, a causa do estado

\footnotetext{
${ }^{253}$ RIBEIRO, José Iran. "Nem oficiais, nem soldados: perfis dos militares de patentes intermediárias do Exército Imperial brasileiro durante a Guerra dos Farrapos” in Lócus: revista de História, Juiz de Fora, v. 15, n. 2, 2009, p. 110. Dossiê Saúde: profissões, ciências e políticas públicas.
} 
decadente em que se encontrava o aldeamento não residia somente na dificuldade encontrada pelos políticos e religiosos em 'civilizar' os índios através dos métodos até então empregados, como a catequese, por exemplo, mas nos serviços militares prestados pelos índios. Entretanto, isso comprometia o futuro dos aldeamentos, inclusive o de São Nicolau do Rio Pardo. Segundo o conselheiro ${ }^{254}$ :

Pouco posso adiantar-vos a respeito desse aldeamento, cuja direção está a cargo Joaquim José da Fonseca Souza Pinto. Sou informado do seu estado de decadência. Os índios moços podendo trabalhar na cultura das boas terras, em que estão situados, distraem-se com o serviço militar, e se empregam em muitos outros misteres fora do aldeamento. Os que estão de efetiva residência são na maior parte velhos e inválidos. (...) A sua pequena capela, há pouco restaurada, reclama por um sacerdote.

Índios guaranis possuíam marcas dos conflitos em seus corpos. Diante dessa situação, cabe questionar como os índios moços poderiam trabalhar no cultivo da terra de um lugar que se encontrava em decadência e sofria consecutivas ameaças de extinção e esquecimento da sua existência? Além disso, tendo em vista a maioria de idosos inválidos e aleijados, será mesmo que o serviço militar teria representado uma distração para os índios que participaram dele? Certamente, a participação em guerras não foi uma opção inteiramente vantajosa para os índios, mas se alguns deles, dentre aqueles que puderam, fizeram essa escolha, talvez a perspectiva da mutilação física representasse algo preferível a outros tipos de perda. Assim também, os índios e índias que permaneceram em São Nicolau do Rio Pardo lutaram com outras armas, fazendo uso daquelas que possuíam, como por exemplo, o esforço em manter a capela reformada. Mesmo vivendo em situações de extrema carestia e mesmo que a maioria dos habitantes do aldeamento fosse composta por mulheres e velhos aleijados e inválidos a capela se manteve reformada, e tal fato chamava a atenção dos políticos e religiosos. Outro ponto que merece destaque é que havia guaranis letrados. Eles poderiam se tornar bastante valorizados num cenário em que "a reorganização do Exército, aumentou enormemente a precisão de indivíduos capazes de

\footnotetext{
${ }^{254}$ AHPA. Relatório apresentado à Assembléia Provincial de São Pedro do Rio Grande do Sul, na segunda sessão da S. Legislatura pelo Conselheiro Joaquim Antão Fernandes Leão, 1859.
} 
desempenhar funções burocráticas intermediárias" ${ }^{255}$. Como alguns guaranis eram letrados e possuíam experiências e habilidades em situações de guerras eles poderiam se destacar dentro do Exército e seus préstimos no serviço militar foram, em algumas ocasiões, muito valorizados. Ainda segundo José Iran Ribeiro, o fato de a maioria dos soldados que atuaram na guerra dos Farrapos não terem ultrapassado postos inferiores não significava insucesso, “afinal, foram sujeitos que galgaram os escalões subalternos e, a partir deles, ascenderam na escala social daquela sociedade fortemente hierarquizada" 256 . Dentro do aldeamento houve estratégias utilizadas para manter os direitos dos índios, e fora dele uma delas pode ter sido o serviço prestado nas guerras. Neste mesmo ano de 1858, Manoel Pires Leis, o diretor de São Vicente, outro aldeamento guarani que havia sido recentemente fundado, informava ao diretor geral dos índios o seguinte ${ }^{257}$ :

Propus aos guaranis de famílias a exigência do Sr. Presidente tendente aos seus filhos menores e me responderam negativamente sobre a entrega destes para a Companhia dos oficiais marinheiros, porém que tem prazer e satisfação em vê-los empregados nos corpos da $1^{a}$ Linha ou tropa da guarda nacional logo que possam com o peso da espada ou da lança, como tem feito até o presente.

Ao que parece, houve situações em que os índios permitiram que seus filhos fossem recrutados, arriscando suas vidas e sua integridade física ao prestarem serviços militares. A constância dessas ações revela que havia fortes motivos para isso. Uma pista está no prestígio alcançado pelos índios, que nesse caso, permitiu que eles negassem um pedido do presidente da Província. Os filhos dos guaranis de São Vicente não lutariam como oficiais marinheiros, como requisitou o governo, mas em tropas da Guarda Nacional. O diretor de São Vicente acrescentou outras informações que respaldavam os dizeres dos índios sobre estarem, continuamente, prestando serviços militares à Província. Naquele momento não era possível retirar os animais que se encontravam no lugar, porque seus donos estavam ausentes, prestando serviços no Exército da companhia daquele distrito. Junto ao serviço

\footnotetext{
255 RIBEIRO, José Iran. Op. Cit. p. 110.

${ }^{256}$ IDEM.

257 AHRS, Correspondência ativa de Manuel Pires Leis; José Joaquim de Andrade Neves. Diretor da Aldeia de São Vicente, maço 2, 1859. Distrito de São Vicente. 2 de setembro de 1858.
} 
militar pareciam estar atreladas outras atividades importantes à economia provincial, como a criação de animais ${ }^{258}$ :

Expus a S. Excia. o Sr. Presidente as circunstâncias em que se achava o rincão da Timbaúva, o qual está ocupado por considerável número dos animais pertencentes aos guaranis deste Distrito, que era impossivel remover os ditos animais para outra parte, a causa que os seus proprietários em número de sessenta e tantos se acham no Exército fazendo parte da companhia deste mesmo distrito.

O aldeamento de São Vicente foi fundado com o objetivo principal de reunir os índios oriundos do aldeamento de São Nicolau, que se encontrava em vias de extinção. Apesar do prestígio de que gozavam alguns guaranis, em 1861, o presidente da Província afirmava que o único motivo pelo qual São Nicolau do Rio Pardo ainda constaria no relato sobre os aldeamentos era o fato de "ser ainda conservado um diretor estipendiado pelos cofres provinciais" ${ }^{259}$ :

Sem dúvida é tal alvitre preferível ao congregar nesse ponto (em São Nicolau do Rio Pardo) os índios dos aldeamentos extintos, segundo propõe o diretor geral, tanto mais que se prossegue na legitimação das posses dos que residem no Rincão de São Vicente ${ }^{260}$.

Para o presidente da Província era melhor fundar um novo aldeamento guarani, do que reunir os índios dos aldeamentos extintos em São Nicolau do Rio Pardo, afinal este próprio aldeamento estaria em vias de extinção. Os prováveis motivos pelos quais a presidência da província havia tomado como medida a transferência dos índios de São Nicolau do Rio Pardo para São Vicente foram as disputas de terra entre indígenas, colonos e 'nacionais', suas vendas e apropriações conforme visto no capítulo 3. A presença dos índios em São Nicolau do Rio Pardo, sua posição de proprietários das terras do aldeamento e suas reivindicações representavam um entrave para políticos e setores da elite. Por outro

\footnotetext{
${ }^{258}$ IDEM.

${ }^{259}$ AHPA. Relatório do Vice-Presidente da Província de São Pedro do Rio Grande do Sul, Patrício Correa da Câmara, na abertura da Assembléia Legislativa Provincial, 1861.

${ }^{260}$ Os parênteses são meus.
} 
lado, seu esvaziamento também se deu em função das guerras, que contribuíram para a 'decadência' da agricultura no mesmo, e conseqüentemente, para justificar apropriações de suas terras por terceiros alegando improdutividade. Mesmo assim, a participação dos índios nos conflitos não cessou. Tampouco impediu suas tentativas de manter o território do aldeamento. Isso demonstra que as opções de participar dos conflitos bélicos e manter a posse do território do aldeamento não se apresentaram como opções excludentes para os índios, como pensavam os 'colonos' e os 'nacionais'. Em primeiro lugar, os índios que lutavam para manter o território nem sempre eram os mesmos que atuavam nos conflitos. Em segundo, atuar nos conflitos poderia render títulos e posses de terras aos militares com bom desempenho, como parecia ser o caso dos índios de São Vicente. Mesmo que tais bens materiais e de prestígio não fossem alcançados, era possível conseguir alimento participando das campanhas militares, como se verá na próxima parte deste capítulo. O documento sobre o aldeamento de São Vicente nos revela que os índios não consideravam as guerras inteiramente vantajosas para si e para seus filhos. Não parece que tinham gosto por atuar em qualquer conflito ou mesmo em qualquer Companhia de oficiais, mas escolhiam onde lutar e sabiam da importância de sua atuação no presente e no passado. Usaram seu prestígio militar para fazer políticas indígenas, para as quais a ocupação e posse de território eram importantes, haja vista a afirmação dos índios de São Vicente de que não sairiam daquele lugar. Suas atitudes não foram vinculadas a aspectos deliberadamente culturais. Foram pautadas pelas suas trajetórias históricas, em que destacaram sua atuação constante nos conflitos, revelando que figuraram como parte integrante dos projetos políticos da Província. Suas reivindicações, em alguns casos, foram aceitas pelo governo. O diretor não redarguiu aos argumentos e à negação do pedido feito aos guaranis, mas possivelmente tenha acatado à decisão deles em permanecer naquelas terras e não cederem seus filhos à companhia dos oficias marinheiros. Os filhos das famílias de São Vicente não serviriam ao exército em atividades que os índios não julgassem devidamente valorizadas. A relação entre a atuação dos índios nos conflitos militares parece ter ocasionado a posse de territórios em algumas situações e a perda deles em outras 261 :

${ }^{261}$ AHRS. Fundo Indígenas, Correspondência ativa José Joaquim de Andrade Neves. Diretoria geral dos Índios, maço 3, 1 de janeiro de 1849. 
A aldeia de São Nicolau atualmente habitada por trezentos $e$ oitenta indios guaranis de ambos os sexos, em grande parte velhos e meninos, pouco tem prosperado porque com a passada revolução que tudo assolou, dela foram tirados muitos braços, que conservados certamente a teriam feito florescer, agora porém que é passada a causa de sua decadência, e ela tomará incremento e poderá ainda dali sair para o exército muitos bons soldados como já aconteceu.

O diretor do aldeamento afirmou repetidamente que os guaranis eram bons soldados. As trajetórias de alguns indivíduos junto ao serviço militar podem ter criado símbolos capazes de marcar diferenças entre os índios de São Nicolau do Rio Pardo e de outros aldeamentos e mesmo entre os índios guaranis e outras parcialidades. Ao mesmo tempo, o prestígio adquirido se associa aos feitos do passado e constituem um amálgama para o sentimento de pertencimento e para a manutenção de uma memória política capaz de assegurar a posse de territórios pelos índios, além da permanente construção de uma identidade étnica no presente e para o futuro. No caso dos índios de São Vicente, guaranis de família confirmaram que continuariam a participar das atividades militares "como têm feito até o presente". É nesse sentido que considero o uso do conceito de etnogênese bastante apropriado para pensar as dinâmicas sociais que envolveram as trajetórias dos índios de São Nicolau do Rio Pardo. Segundo Jonathan Hill ${ }^{262}$ :

Ethnogenetic processes are intrinsically dynamic and rooted in a people's sense of historical consciousness, or 'a reflexive awareness on the part of social actors of their ability to make situacional and more lasting adjustments to social orderings ... and an ability to understand that ordering as it is situated in larger, more encompassing spatiotemporal orders that include others who are socially different' (Hill 1988:7).

As mudanças advindas com as guerras, o esvaziamento do aldeamento, os deslocamentos territoriais dos índios, seu recrutamento e as formas de militarização pelas quais passaram revelam sua grande capacidade em lidar com acontecimentos históricos. Relações de parentesco, de reciprocidade, disputa e conflito fizeram parte das estratégias políticas acionadas por eles em situações difíceis, como foi o caso de várias

${ }^{262}$ HILL, Jonathan D. (org). History, power and identity: ethnogenesis in the Americas, 1492-1992. Iowa City: University of Iowa Press, 1996, p. 1-2. 
famílias guaranis que se deslocaram até de São Nicolau do Rio Pardo e matricularam seus filhos na escola do aldeamento, como vimos no capítulo anterior. Se o conflito civil havia sido responsável pela ausência de braços que teriam feito o aldeamento prosperar, como afirmou o diretor geral dos índios, estes foram também os braços que em outras situações atuaram em guerras civis e entre províncias. $\mathrm{O}$ mesmo diretor não escondeu a importância e tampouco a necessidade daqueles bons soldados para a Província de São Pedro. Isso nos mostra que a memória e o valor da participação dos índios nas guerras não eram compartilhados somente entre eles, mas estava presente nos discursos e na memória de viajantes estrangeiros, religiosos e autoridades políticas da Província. Esses atos dos guaranis são fatos reais e fazem parte da história e da cultura indígena e sul-rio-grandense.

\section{4 - “ESTES ÍNDIOS SÃO BONS SOLDADOS”}

Um documento histórico notável e inédito intitulado de Memorial sobre os Guaranis, do ano de 1865, narra um episódio revelador sobre a atuação dos índios nas guerras da Província. De acordo com ele, um ano após o início da guerra do Paraguai, três índios coroados, oriundos do toldo de um cacique conhecido por Fongue, acompanhados de cerca de cento e cinquenta a duzentos guaranis procuraram por uma estância em particular, onde se encontrava o presidente da Província. Os indígenas coroados, provenientes do aldeamento da Guarita, argumentaram que se sentiam obrigados a servirem como voluntários do exército. Eles não só se achavam autorizados pelo cacique Fongue a prestarem tais serviços, como tiveram essa autoridade reconhecida e se permitiu que "fizesse a reunião no toldo, ou taba de baixo, sob a direção do capitão", dando "aos mesmos o armamento a fuzil, equipamentos, arreios, cavalos e o fardamento que for necessário" 263. Tal autorização, assim como os animais e os materiais, teria a sua concessão ordenada através de uma portaria baixada pelo presidente da Província, o

\footnotetext{
${ }^{263}$ AHRS, Memorial sobre os Guaranis, do Visconde de Boa Vista apresentado à Presidência da Província, Diversos, maço 5, agosto de 1865. Os dois últimos trechos são citações deste documento.
} 
Visconde de Boa Vista ${ }^{264}$. Juntos, os índios formaram uma comitiva e foram à estância onde estava a mais alta autoridade política provincial buscar recursos que permitissem a sua participação na guerra do Paraguai.

A notícia sobre a guerra corria e colocava os habitantes da Província em estado de alerta. Entre os motivos principais que poderiam ocasionar uma guerra estavam aqueles de ordem econômica. "O preço acessível da terra e a qualidade dos pastos eram bastante atrativos e pode-se dizer que, em meados do século XIX, aquela região era praticamente um apêndice econômico e social dos estancieiros rio-grandenses" ${ }^{265}$. Em 1850, o diretor geral dos índios na Província escreveu ao Ministro do Império informando sobre as plantações e ramos de comércio dos aldeamentos. Sobre os índios de São Nicolau do Rio Pardo escreveu $^{266}$ :

Estes índios são bons soldados, e peões, viviam também de conduzir tropas para as charqueadas e de trabalharem nelas, donde tiravam recursos, porem há três anos que tem decaído este ramo de comércio, o mais forte da Província. Essa [é a] razão de os charqueadores não poderem competir em preço com o charque que é introduzido pelos nossos vizinhos, que só tem de despesa o fabrico, porque dos gados tirados aos brasileiros afazendados no estado oriental para corear, dão a carne gratuita a quem a quer beneficiar ${ }^{267}$.

Nessa fonte histórica, as atividades dos índios guaranis aparecem ligadas às charqueadas, ao comércio e à guerra. De acordo com Susana Bleil Souza e Fabrício Prado, a economia movimentada pelo charque na Província poderia provocar uma considerável crise econômica e política, caso a continuidade dessa atividade fosse impedida ou interrompida por qualquer motivo ${ }^{268}$. De certa forma, as invasões territoriais deflagradas com a guerra do Paraguai e o próprio clima conflituoso poderiam vir agravar a crise, que já

\footnotetext{
${ }^{264}$ O nome do então presidente da Província era Francisco do Rego Barros.

${ }^{265}$ VARGAS, Jonas Moreira. "O Rio Grande do Sul e a guerra do Paraguai", in GRIJÓ, Luis Alberto; NEUMANN, Eduardo Santos (org.). Continente em armas: uma história da guerra no sul do Brasil. Rio de Janeiro, Apicuri, 2010, p. 126.

${ }^{266}$ AHRS, Fundo Indígenas. Diretoria Geral dos índios. Correspondência Ativa José Joaquim de Andrade Neves, 01 de janeiro de 1850.

${ }^{267} \mathrm{O}$ grifo é meu.

${ }^{268}$ SOUZA, Susana B.; PRADO, Fabrício. "Brasileiros na fronteira uruguaia: economia e política no século XIX”, in GRIJÓ, Luiz Alberto; KÜHN, Fábio; GUAZELLI, César Augusto Barcellos; NEUMANN, Eduardo Santos (orgs.). Capítulos de Historia do Rio Grande do Sul. Porto Alegre, EDUFRGS, 2004.
} 
havia se iniciado. Nesse sentido, a decisão e a atitude tomada pelos índios que procuram o presidente da Província a fim de participar na guerra do Paraguai foi significativa. Seus alistamentos poderiam contribuir para tanto acelerar o término do conflito, quanto garantir que o desfecho dele fosse positivo para o Império brasileiro. Suas participações também poderiam significar uma possibilidade maior de se deslocarem, podendo até mesmo encontrar parentes durante as incursões militares e os combates. Por fim, o prestígio e o reconhecimento dos serviços militares prestados por eles poderiam representar uma alternativa para conseguir terras e suprimentos durante um período que era de carestia, como de fato ocorreu. É especialmente importante refletir sobre essas duas últimas hipóteses se levarmos em conta a 'voluntariedade' dos índios nesse episódio, quando é sabido que muitas imagens foram construídas sobre a guerra do Paraguai, entre elas, a de que se tratava de uma guerra da civilização moderna contra a "barbárie" paraguaia, cuja natureza era indígena e guarani e deveria ser derrotada ${ }^{269}$. Para os guaranis, entretanto, a mesma guerra pode ter representado um bom motivo para estabelecer ou acionar laços e relações de parentesco. Relações de solidariedade também podem ter estado diretamente relacionadas aos deslocamentos espaciais dos guaranis naqueles tempos de guerra.

Outro ponto que chama a atenção nessa fonte histórica é a disparidade entre o número de índios coroados e guaranis. Por um lado, parece estranho que tantos guaranis estivessem acompanhados de apenas três índios coroados, com o intuito de juntos irem à guerra. À primeira vista, o mais plausível seria que os índios que formaram a comitiva fossem coroados. Por outro lado, também soa estranho que o presidente da Província tenha simplesmente se equivocado e confundido os índios guaranis com os coroados, sobretudo naquele contexto onde os serviços militares prestados pelos índios eram importantes no estabelecimento de alianças com os grupos étnicos. De todo modo, creio que as incongruências presentes no documento remetam a outras importantes questões, às vezes pouco exploradas. A possibilidade de índios de distintos grupos étnicos estarem juntos e/ou de serem vistos como misturados suscitam novas problemáticas. Segundo João Pacheco de Oliveira, “a expressão 'índios misturados' - freqüentemente encontrada nos Relatórios de

\footnotetext{
${ }^{269}$ SILVA, Edson. “Nós vencemos a guerra!"”: história, memória e leituras indígenas da Guerra do Paraguai, in Revista Clio, no 25.2. SILVA, Edson \& CARVALHO, Marcus J. M. de (orgs.). Recife, EDUFPE, 2007, p. 40.
} 
Presidente da Província e em outros documentos oficiais - merece uma outra ordem de atenção, pois permite explicitar valores, estratégias de ação e expectativas dos múltiplos atores presentes nessa situação interétnica" ${ }^{270}$. De fato, a suposta aliança estabelecida entre índios guaranis e coroados ou o possível equívoco cometido pelo presidente da Província revelam aspectos interessantes daquele contexto e escapam à lógica das informações oferecidas pelo documento. De acordo com o Memorial sobre os Guaranis, para que os cerca de cento e cinqüenta a duzentos guaranis conseguissem ir à guerra, os três coroados agiram acionando o passado, e lembraram a Francisco Barros que, em 1851, outros sessenta indígenas já haviam servido às ordens de um capitão chamado Prudente, a quem o presidente sabia já estar falecido no ano de $1865^{271}$ :

Lembra-se a estância que em 1851, já da mesma tribo, 60 homens serviram as ordens do cap. Prudente, hoje falecido, assim como em a mesma ocasião também serviu o $\left[1^{\circ}\right]$ dos [Expe]dicionários.

Assim, foi ordenado que fossem dadas roupas e comida às famílias dos índios, bem como uma indenização àqueles que vinham fornecendo víveres a eles. Os três índios coroados, a saber, Antônio Portella, Manoel Feliciano e Manoel da Silva, foram respectivamente nomeados pelo presidente da Província como capitão, tenente e alferes da “Companhia ou Corpo que os mesmos formaram com cerca de duzentos guaranis", 272 . A comitiva foi reconhecida pela mais elevada autoridade política da Província como uma companhia militar e iria atuar na guerra segundo foi da vontade dos índios, como uma infantaria montada.

270 OLIVEIRA, João Pacheco de. "Uma Etnologia dos 'Índios Misturados': Situação Colonial, Territorialização e Fluxos Culturais", João Pacheco de OLIVEIRA (org.), A Viagem da Volta: Etnicidade, Política e Reelaboração Cultural no Nordeste Indígena, Rio de Janeiro [2 $2^{\mathrm{a}}$ Ed.], Contra Capa, 2004, p. 19.

${ }^{271}$ AHRS, Memorial sobre os Guaranis, do Visconde de Boa Vista apresentado à Presidência da Província, Diversos, maço 5, agosto de 1865.

${ }^{272}$ IDEM. 
No Guia Histórico de Rio Pardo, Dante de Laytano ${ }^{273}$ traz informações importantes sobre a escola militar preparatória da Província de São Pedro do Rio Grande do Sul, criada e organizada por decreto em 1858. Embora já funcionasse na cidade de Rio Pardo uma escola militar preparatória, devido ao decreto, foi fundada uma escola militar auxiliar em 1860. Neste mesmo ano, foram designados e mandados apresentar à escola cerca de quarenta alunos para servirem como adidos ao $3^{\circ}$ e ao $4^{\circ}$ Batalhão de Infantaria. Apesar de haver três batalhões de infantaria e cinco regimentos de cavalaria e artilharia a cavalo, os alunos foram designados para servirem na infantaria. Ao que tudo indica, o $1^{\circ}$ Regimento de Artilharia a Cavalo, o $2^{\circ}$, o $3^{\circ}$, o $4^{\circ}$ e o $5^{\circ}$ Regimento de Cavalaria da escola militar de Rio Pardo já estavam completos. Pode ser que estes tenham sido os destacamentos militares mais procurados pelos servidores do Exército na Província. O estatuto social da posse de cavalos de combate nas guerras geralmente é visto como um sinal de riqueza e de prestígio $^{274}$. Devido ao seu papel militar decisivo, sobretudo como meio de transporte, e as consideráveis despesas em termos de criação, treino, alimentação e equipamento, a cavalaria quase sempre esteve associada a um estatuto social elevado. Nos exércitos nacionais, ser um oficial de cavalaria continuava a ser sinal de distinção e privilégio. E a comitiva de índios que procurou pelo presidente da Província parecia saber disso ${ }^{275}$ :

A estância mandará dar aos mesmos o armamento a fuzil, equipamentos, arreios, cavalos e fardamento que for necessário, $e$ a vontade de V. Ex $x^{a}$. Os chefes se obrigam por si e por seus companheiros a servirem como Infantaria montada.

É possível que os guaranis estivessem mais familiarizados com os códigos e os estatutos sociais militares do que os coroados, haja vista a constante presença dos guaranis atuando nos conflitos bélicos e a existência de uma escola militar preparatória sediada em Rio Pardo. Não é raro encontrar nas fontes históricas a presença de índios guaranis

${ }^{273}$ LAYTANO, Dante de. Guia Histórico de Rio Pardo. Porto Alegre: Edição da Prefeitura Municipal de Rio Pardo, 1979, p. 93.

${ }^{274}$ SALEMA, Vasco da Costa. Achegas para a História da Cavalaria Portuguesa. Lisboa: Sociedade Histórica da Independência de Portugal, 2000.

${ }^{275}$ AHRS, Memorial sobre os Guaranis, do Visconde de Boa Vista apresentado à Presidência da Província, Diversos, maço 5, agosto de 1865. 
associada a situações que envolvem cavalhadas, roubos de cavalos, e regimentos ou companhias de cavalaria. Isso denota que sabiam da importância dos animais e do valor da prestação desse tipo de serviço naquele contexto de guerra em territórios de fronteira. Todavia, tal possibilidade não inviabiliza aquela de que os coroados também estivessem inseridos nessas atividades e nessas redes sociais. O certo é que as informações trazidas pelo documento, ainda que pareçam contraditórias, demonstram a capacidade dos índios em usar as identidades indígenas e a importância das suas ações no passado e no presente para obter reconhecimento por parte de uma destacada autoridade política. Outra informação relevante é a de que em julho de 1864, Dom Pedro II e sua comitiva haviam desembarcado no porto de Rio Grande, passando por Rio Pardo, São Gabriel, Caçapava, Alegrete e Porto Alegre. Tal viagem promoveu um esforço de guerra, "restabeleceu a ordem militar no Rio Grande do Sul e adquiriu uma dimensão simbólica, com a presença do monarca em uma província com antecedente republicano" ${ }^{276}$. Levando-se tais fatos em conta, é sem dúvida importante pensar que o documento que narra o episódio em que uma comitiva indígena se apresentou para ir à guerra foi oferecido pelo presidente da Província em forma de memorial. Ele ordenou que uma portaria fosse baixada a fim de que todos os recursos fossem concedidos para que os índios pudessem ir à guerra. Escreveu sobre aqueles fatos e sobre outros que lhe foram recordados pelos índios. Tomando como base o título dado ao documento, Memorial sobre os Guaranis, o presidente da Província parece ter querido que tais fatos pudessem ser documentados e ao mesmo tempo guardados para a posteridade. Escreveu sobre acontecimentos que faziam parte do seu presente, mas os apresentou como algo que considerou digno de ser lembrado no futuro. Para isso, considerou apropriado o uso de uma memória política escrita sobre o presente e o passado. Isso demonstra o quanto pode ter sido complicado para os políticos da Província de São Pedro lidar com a necessidade de resguardar as 'memórias da Província' para que elas, um dia, pudessem fazer lembrar algo que não podia ser esquecido, tampouco negado: a participação dos índios em conflitos bélicos. Nesse sentido, não se pode esquecer que os guaranis da Província também eram associados à imagem de um índio do passado, que só havia existido no tempo das missões. Assim, resguardar a memória e a presença de índios

${ }^{276}$ DORATIOTTO, Francisco. Op. Cit. 2002, p. 179-180. 
considerados extintos ou misturados pode ter feito com que o presidente da Província escrevesse um documento nomeado por ele de Memorial sobre os Guaranis.

Esse documento está no Arquivo Histórico do Rio Grande do Sul e faz parte de um conjunto de documentações avulsas sobre o tópico Catequese. Encontra-se junto aos documentos avulsos, já que não há nenhum outro tipo de documento memorialístico como ele entre os demais. Trata-se do único memorial escrito sobre os índios encontrado até o momento. Pode-se mesmo imaginar o impacto que o presidente sentiu ao ver cerca de duzentos índios reunidos negociando para irem à guerra do Brasil contra o Paraguai, sabendo das suas condições de vida e do modo como eram tratados na Província. Sob esse prisma, seria difícil compreender porque eles pareciam estar interessados em defender os interesses territoriais do Brasil. Do mesmo modo, seria quase impossível supor que essa guerra pode ter sido entendida por eles como legitimamente sua, já que faziam parte dos moradores da Província.

O Memorial sobre os Guaranis está em meio a outros documentos que foram nomeados como Perseguição aos índios em Vacaria (1851), Perseguição aos índios no distrito de Torres (1851), Companhia de Pedestres do Município de Vacaria (1853), Relação de artigos emprestados para o serviço dos índios (1864), Comissão Missioneira ao Presidente do Estado (1904). Esses documentos carregam em seus títulos marcas das violências cometidas contra os índios, ao passo que, estão em meio a outro documento escrito, entre outros prováveis motivos, para preservar uma memória sobre os guaranis. Do mesmo modo, os títulos deixam claro que a admiração que os índios causaram em algumas situações não impediu que houvesse tentativas de exterminá-los em outras. Esse parece ser o caso dos índios coroados de Torres e Vacaria. É ainda interessante observar que o episódio em que uma comissão missioneira procurou pelo presidente do Estado em 1904, não se tornou um memorial sobre os índios. Com certeza, as conjunturas que estruturaram os acontecimentos eram diferentes, e os tratamentos direcionados aos índios também foram muito distintos. Nesse sentido, de acordo com o documento analisado, é interessante interligar os dados que as fontes trazem: em 1851 índios eram perseguidos em Torres e Vacaria. Neste mesmo ano, sessenta índios coroados haviam servido ao exército brasileiro e outros três lembraram o fato ao presidente da Província catorze anos depois (em 1865). Isso 
pode ter contribuído não só para que as ações dos índios fossem consideradas memoráveis pelo presidente da Província, mas para que suas famílias tivessem a chance de se alimentar e de se vestir, mesmo que isso não significasse uma garantia de sobrevivência permanente, como aliás, o presidente fez questão de salientar ${ }^{277}$ :

A estância mandará dar algum vestuário e mantimentos de boca às famílias destes voluntários até a primeira colheita, o que nunca pode ser excessiva, porque com pouco se contentarão as suas famílias. Bastará que se lhes mande dar carne e algumas peças de [ilegível] de algodão e botas.

Ele argumentou que os mantimentos não poderiam ser excessivos, pois as famílias dos índios se contentariam com pouco e bastava que lhes dessem pouca comida, roupas e calçados em quantidade a ser estipulada pela presidência da Província. No entanto, o que pode ter sido avaliado pelo presidente como pouco com o que se contentar - a garantia da sobrevivência provisória das famílias - certamente foi avaliado pelos índios como importantes, apesar de as guerras colocarem suas vidas em risco. Dessa forma, considero que o aspecto que mais chama a atenção na situação descrita pelo documento, não é somente a aliança estabelecida entre uma autoridade imperial e os indígenas coroados para a defesa e garantia das fronteiras nacionais, ou a aliança estabelecida entre coroados e guaranis em prol de um objetivo em comum, mas o uso da guerra como estratégia acionada pelos índios na luta pela sobrevivência física e étnica.

Conforme o que foi exposto, há pistas para pensar na atuação dos índios guaranis nas guerras a partir de limitações e delimitações sociais, culturais, étnicas e políticas. Como parte integrante desse contexto, podemos apontar as políticas indígenas, indigenistas e os discursos que contribuíram para construir diferenças identitárias. É preciso considerar tais diferenças a partir das conjunturas históricas, afinal, como vimos no primeiro capítulo, os debates e as tensões que agitaram os círculos intelectuais e os gabinetes científicos e políticos da jovem nação brasileira encontraram ecos na Província do Rio Grande. Isso

\footnotetext{
${ }^{277}$ AHRS, Memorial sobre os Guaranis, do Visconde de Boa Vista apresentado à Presidência da Província, Diversos, maço 5, agosto de 1865.
} 
contribuiu para a formação de discursos políticos que, apesar de reproduzirem tais tensões e debates, estiveram inevitavelmente cerceados pelas experiências e particularidades vividas no contexto da Província. 


\section{CONSIDERAÇÕES FINAIS}

Nesta pesquisa buscou-se apresentar aspectos históricos das vidas de índios guaranis na Província do Rio Grande de São Pedro. Esse assunto ainda não havia sido estudado pela historiografia e espero ter contribuído para o conhecimento sobre seus atos registrados nos documentos históricos.

Os guaranis de São Nicolau do Rio Pardo estiveram ligados ao território do aldeamento durante todo o período entre sua formação e extinção. Isso se deu através das relações estabelecidas a partir da igreja e da escola, no cultivo da erva-mate, nas disputas pelas terras do aldeamento e no envolvimento com as atividades militares. Em alguns casos houve deslocamentos espaciais e mudanças sociais em virtude dessas experiências. Tais relações fizeram parte das reelaborações culturais e identitárias e contribuíram para que eles atuassem ativa e diferentemente em prol de seus interesses. Através da manutenção daquele espaço mantiveram uma identidade indígena, que foi constantemente transformada por inúmeros acontecimentos. As ações dos índios se deram no sentido de evitar a perda de privilégios e de auxiliar no ganho de outros benefícios, embora nem sempre com sucesso.

As fronteiras entre suas identidades e seus direitos territoriais se mostraram flexíveis. O uso estratégico dos limites fronteiriços e identitários apresentou-se para eles como uma possibilidade de controle sobre suas histórias, através da sua capacidade de articular fatos ocorridos no passado e no presente para pensar e decidir sobre o futuro. Nesse sentido, as atividades militares e os eventos bélicos continuaram, sem dúvida, a fazer parte do sentimento de pertencimento identitário para os guaranis que se movimentaram entre a região das Missões, o Estado Oriental, o Paraguai, Entre-Rios, São Nicolau do Rio Pardo e São Vicente. Suas participações nos conflitos não parecem dizer respeito a um suposto 'ethos guerreiro', mas sim ao conjunto de ações que figuram como parte dessa história indígena, que é também história da Província de São Pedro e história do Brasil. Interligados através de relações sociais complexas, os índios utilizaram suas memórias e atuação diante dos fatos históricos para mobilizar redes sociais em prol de objetivos em comum. Desse modo, para o caso dos índios de São Nicolau do Rio Pardo, as categorias utilizadas para classificar suas tradições culturais se mesclam às diferentes experiências vividas por eles, dando forma à sua história. Tais categorias simbolizaram condições de 
coesão social e identificação étnica e política. Foram usadas no estabelecimento ou na legitimação de direitos indígenas no que diz respeito às terras do aldeamento e aos privilégios legais concedidos aos índios. Também foram usadas para socializar valores e padrões de comportamento, pois se tratava de índios com uma identidade étnica guarani, uma condição política de aldeados, uma identidade religiosa cristã e aliados nas guerras para defesa, demarcação e manutenção dos limites fronteiriços no sul do Brasil. Nesse sentido, ao longo do tempo eles foram vistos e se fizeram ver como desertores, ladrões, 'chinas', 'seduzidos', letrados, ignorantes, ervateiros, lavradores, guerreiros, peões, soldados, músicos, cossacos, indigentes, cristãos, colonos, brasileiros. Todas as facetas desse complexo processo histórico que construiu e reconstruiu identidades pôde transformar aos índios e aos outros.

As ações dos guaranis fizeram parte de muitas histórias e de alguma maneira elas se apresentam nos discursos produzidos sobre eles. Para além da tendência presente nos discursos de políticos e religiosos sobre os índios no século XIX - que ora os invisibilizou, ora os incapacitou, ora os enalteceu - nas suas entrelinhas encontram-se muitas histórias ricas e até então, praticamente desconhecidas, como a do aldeamento de São Nicolau do Rio Pardo. Assim, jamais teria sido possível esgotar essa temática ao longo do trabalho. Entretanto, talvez seja mais importante apontar que muitos outros estudos serão necessários para dar a ver o que permanece escondido e desconhecido sobre as histórias dos índios em fontes dos arquivos históricos espalhados pelo mundo, à espera dos historiadores. 


\section{LOCAIS DE PESQUISA}

AGN - Archivo General de la Nación (Argentina)

AGS - Archivo General de Simancas (Espanha)

AHMRP - Arquivo Histórico Municipal de Rio Pardo

AHPA - Arquivo Histórico de Porto Alegre

AHRS - Arquivo Histórico do Rio Grande do Sul

ANRJ - Arquivo Nacional do Rio de Janeiro

BNL - Biblioteca Nacional de Lisboa

BNRJ - Biblioteca Nacional do Rio de Janeiro

IHGRGS - Instituto Histórico e Geográfico do Rio Grande do Sul

\section{FONTES CONSULTADAS}

\section{Fontes impressas}

DIRETÓRIO que se deve observar nas povoações dos índios do Pará e do Maranhão enquanto sua majestade não mandar o contrário. In: ALMEIDA, Rita Heloísa de. $O$ Diretório dos Índios. Um projeto de civilização no Brasil do século XVIII. Brasília: Editora UnB, 1997, p. 63-93.

AVÉ-LALLEMANT, Robert. Viagem pela Província do Rio Grande do Sul (1858). Belo Horizonte: Itatiaia, 1980.

DREYS, Nicolau. Notícia Descritiva da Província do Rio Grande de São Pedro do Sul. Porto Alegre. IEL, 1961.

SAINT-HILAIRE, Auguste. Viagem ao Rio Grande do Sul (1820-1821). Tradução de Adroaldo Mesquita da Costa. $2^{a}$ ed., Porto Alegre: Martins Livreiro, 1987. 
SCHUPP, Pe. Ambros. A missão dos jesuítas alemães no Rio Grande do Sul. São Leopoldo: Editora Unisinos, 2004 [1912].

VIEIRA, Antônio. "Relação da missão da Serra de Ibiapaba escrita pelo padre Antônio Vieira e tirada do seu mesmo original” in Sermões, São Paulo, Editora das Américas, 1957.

\section{Fontes datiloescritas}

INSTITUTO HISTÓRICO E GEOGRÁFICO DO RIO GRANDE DO SUL. DIAS LOPES, Vicente Zeferino. "Comentário Eclesiástico do Rio Grande de São Pedro do Sul desde 1737’. Cópia datilografada. Original: 1891. Caixa D, nº 10.

\section{Fontes manuscritas}

Códices Gerais (números 01 a 92), [1809 a 1891], Fundo: Câmara Municipal, Série: Correspondência; Livro de Correspondências (números 01 a 07), [1860 a 1892], Fundo: Câmara Municipal, Série: Correspondência. Arquivo Histórico do Município de Rio Pardo.

Códice 10854. Divisão de Reservados. Biblioteca Nacional de Lisboa.

Correspondência ativa de José Joaquim da Fonseca e Souza Pinto, Fundo: Índios, Aldeamento, Diretoria do Aldeamento de São Nicolau, maço 2, [1848, 1852, 1871]; maço 3 $[1848,1849,1850,1851,1852,1853,1854,1855,1856,1857,1858,1859,1860]$; maço 4 [1861, 1862, 1863, 1864, 1865, 1866, 1867]. Arquivo Histórico do Rio Grande do Sul.

Legajo 7405, documento 71: Quartel General de San Borxa. Año de 1759. Secretaria de Estado. Archivo General de Simancas (Valladolid - Espanha).

Mapa estatístico das conciliações propostas pelos juizados de paz de Rio Pardo. Maço 1, 1833. Fundo Estatística. Livro de estatística judicial dos juizados de paz (1830-1844). Arquivo Histórico do Rio Grande do Sul.

Microfilme: 024-97. Fundo: Marquês do Lavradio. Arquivo Nacional do Rio de Janeiro.

Obras Públicas. Secretaria de Estado de Negócios das Obras Públicas. Anexo ao Relatório [1897-1898]. Arquivo Histórico do Rio Grande do Sul. 
Relatórios dos Presidentes da Província, Catequese e Civilização dos Índios, [1852, 1857, 1859, 1861, 1862, 1863]. Arquivo Histórico de Porto Alegre.

Requerimentos, maço 9, 1813. Fundos Militares. AHRS.

Tomo II - 35, 36, 1. Biblioteca Nacional do Rio de Janeiro.

\section{Fontes orais}

Entrevista oral concedida por Leoncina e Eloí Tatsch em 06 de agosto de 2010, na cidade de Porto Alegre.

\section{Fontes iconográficas}

Fundo Iconografia, Pasta 50, Missões - 042. Arquivo Histórico do Rio Grande do Sul.

\section{BIBLIOGRAFIA:}

AGUILERA, Miguel Olmos (coord). Antropología de las fronteras: alteridad, historia e identidad más allá de la línea. Ciudad de México, Miguel Angél Porrúa, 2007.

ALADRÉN, Gabriel. Liberdades negras nas paragens do sul: alforria e inserção social de libertos em Porto Alegre, 1800-1835. Rio de Janeiro: Editora FGV, 2009.

ALMEIDA, Maria Regina Celestino de. Metamorfoses indígenas: identidade e cultura nas aldeias coloniais do Rio de Janeiro. Rio de Janeiro: Arquivo Nacional 2003.

. "Apresentação" in Os índios na História: abordagens interdisciplinares, Revista

Tempo, Rio de Janeiro, $\mathrm{n}^{\circ} 23$, vol. 12, p. 1-4, Julho de 2007. Disponível em: http://www.historia.uff.br/tempo/artigos_dossie/v12n23a01.pdf

- "Comunidades indígenas e Estado nacional: histórias, memórias e identidades

em construção (Rio de Janeiro e México - séculos XVIII e XIX)", in ABREU, Martha, SOIHET, Rachel, GONTIJO, Rebeca (org.). Cultura política e leituras do passado: historiografia e ensino de história. Rio de Janeiro: Civilização Brasileira, 2007. 
ALMEIDA, Rita Heloísa de. O Diretório dos Índios. Um projeto de civilização no Brasil do século XVIII. Brasília: Editora UnB, 1997.

ARAÚJO, Sarissa Carneiro. “A história (1576) de Gândavo: notas para uma releitura desde a retórica e a gramática" in Lócus: revista de História, Juiz de Fora, v. 15, n. 2, 2009, p. 71 83.

BARCELOS, Artur H. F. Espaço e arqueologia nas missões jesuíticas: o caso de São João Batista. Porto Alegre, EDIPUCRS, 2000.

BOCCARA, Guillaume. Memoria Americana. Cuadernos de Etnohistoria. "Génesis y estructura de los complejos fronterizos euro-indígenas, repensando los márgenes americanos a partir (y más allá) de la obra de Nathan Wachtel”. Buenos Aires. Número 13. 2005.

- "Etnogénesis mapuche: resistência y restructuración entre los indígenas del Centro-Sur de Chile (siglos XVI-XVIII)", Hispanic American Historical Review, 79:3 (1999).

BOEIRA, Nelson; GOLIN, Tau (coord.). KERN, Arno; SANTOS, M. Cristina; GOLIN, Tau (dir). Povos Indígenas. Passo Fundo, Méritos, 2009, Vol. 5. (Coleção história geral do Rio Grande do Sul).

BORGES, Jorge Luis; GUERRERO, Margarida. O livro dos seres imaginários. $8^{\mathrm{a}}$ edição. Editora: Globo. 2000.

BRAGONI, Elsa Beatriz \& MATA, Sara Emilia. Entre la Colônia y la República: insurgencias, rebeliones y cultura política en America del Sur. Buenos Aires, Prometeo Libros, 2008.

CARVALHO, Jr. Almir Diniz de. Índios cristãos: a conversão dos gentios na Amazônia portuguesa (1653-1769). Campinas, SP, 2005 (Tese de doutorado).

CARNEIRO DA CUNHA, Manuela. "Introdução a uma história indígena", in História dos índios no Brasil. São Paulo: Companhia das Letras, 1992.

. "Política Indigenista no século XIX", in História dos índios no Brasil. São Paulo: Companhia das Letras, 1992. 
. “Os direitos do índio, ensaios e documentos”. São Paulo: Brasiliense, 1987.

CASTRO, Eduardo Viveiros de. A inconstância da alma selvagem - e outros ensaios de antropologia. São Paulo, Cosac \& Naify, 2002.

CLASTRES, Pierre. A sociedade contra o Estado: pesquisas de antropologia política. São Paulo, Cosac \& Naify, 2003.

DARNTON, Robert. O Grande Massacre dos Gatos, e outros episódios da história cultural francesa. Tradução de Sônia Coutinho. Rio de Janeiro. Graal, 2010, [1986].

DAVIS, Natalie Zemon. Nas margens. (trad.) São Paulo, Cia. das Letras, 1997.

DORATIOTTO, Francisco. Maldita guerra: nova história da guerra do Paraguai. São Paulo, Companhia das Letras, 2002.

DOUGAN, Andy. Futebol \& guerra: resistência, triunfo e tragédia do Dínamo na Kiev ocupada pelos nazistas. Rio de Janeiro, Ed. Jorge Zahar, 2004 (Tradução autorizada pela primeira edição inglesa publicada em 2001 por Fourth Estate, uma divisão da HarperCollins Publishers, de Londres, Inglaterra).

DOURADO, Maria Teresa Garritano. “Tropas femininas em marcha”. Revista Nossa História. Rio de Janeiro: Biblioteca Nacional, ano 2, n. 13, Nov. 2004, p. 18-23.

FAUSTO, Carlos. Inimigos fiéis: História, Guerra e Xamanismo na Amazônia. São Paulo, Editora da Universidade de São Paulo, 2001.

FELLIPE, Guilherme Galhegos. "A lógica do cuñadazgo: relação de troca e dinâmica cultural", in V Mostra de pesquisa do Arquivo Público do Estado do Rio Grande do Sul (2007 : Porto Alegre, RS). Anais : Produzindo História a partir de Fontes Primárias / (org.) Vladimir Ferreira de Ávila. - Porto Alegre: CORAG, 2007, p. 17-30.

FERNANDES, Florestan. Organização social dos Tupinambá. São Paulo, Difusão Européia do Livro, 1963.

FLORES, Moacyr. "A transmigração dos guaranis para a Aldeia de Nossa Senhora dos Anjos" in Anais do II Simpósio Estadual sobre cultura Gravataiense, Gravataí: do êxodo à composição étnica. Gravataí: Secretaria de Educação e Cultura, 1990.

. Negros na Revolução Farroupilha. Porto Alegre: Edições EST, 2004. 
FRAGOSO, Augusto Tasso. A Revolução Farroupilha (1835-1845). Narrativa das Operações Militares. Rio de Janeiro: Almanak Laemmert, 1938.

GARAVAGLIA, Juan Carlos. Mercado interno e economia colonial. México: Editorial Grijaldo, S.A., 1983.

GARCIA, Elisa Frühauf. A integração das populações indígenas nos povoados coloniais no Rio Grande de São Pedro: legislação, etnicidade e trabalho. Dissertação de Mestrado apresentada ao programa de Pós-Graduação em História da Universidade Federal Fluminense, Niterói, 2003.

' 'As diversas formas de ser do índio: políticas indígenas e políticas indigenistas no extremo sul da América Portuguesa'. Niterói, PPG-História/UFF, Tese de Doutorado, 2007.

- "De inimigos a aliados: como parte dos missioneiros repensou o seu passado de conflitos com os portugueses no contexto das tentativas de demarcação do Tratado de Madri”, in Anais de História de Além-mar, vol VIII, 2007, p.123-137.

GINZBURG, Carlo. O Queijo e os Vermes: o cotidiano e as idéias de um moleiro perseguido pela Inquisição. São Paulo, Cia. das Letras, 2006.

1999. . Mitos, Emblemas, Sinais: morfologia e história. São Paulo: Cia das Letras,

GRIJÓ, Luis Alberto; NEUMANN, Eduardo Santos (org.). Continente em armas: uma história da guerra no sul do Brasil. Rio de Janeiro, Apicuri, 2010.

GRIJÓ, Luiz Alberto; KÜHN, Fábio; GUAZELLI, César Augusto Barcellos; NEUMANN, Eduardo Santos (orgs.). Capítulos de Historia do Rio Grande do Sul. Porto Alegre, EDUFRGS, 2004.

GRUZINSKI, Serge. El Pensamiento Mestizo: Cultura Ameríndia e Civilizacion del Renacimiento. Barcelona: Ed. Paidós Ibérica, 2007.

HANSEN, João Adolfo. Alegoria: construção e interpretação da metáfora. São Paulo, SP: Hedra; Campinas, SP: Editora da Unicamp, 2006

HILL, Jonathan D. (org). History, power and identity: ethnogenesis in the Americas, 14921992. Iowa City: University of Iowa Press, 1996.

KLIEMANN, Luiza H. Schmitz. RS: terra e poder - história da questão agrária. Porto Alegre: Mercado Aberto, 1986. 
KÜHN, Fábio. Breve história do Rio Grande do Sul. Porto Alegre: Leitura XXI, 2004 [2002].

. "Um corpo, ainda que particular": irmandades leigas e Ordens Terceiras no Rio Grande do Sul colonial', in História Unisinos,. Vol. 14 № 2 - maio/agosto de 2010.

LANGER, Protásio Paulo. A Aldeia de Nossa Senhora dos Anjos: A resistência do Guarani-Missioneiro ao processo de dominação do sistema colonial luso (1762-1798). Porto Alegre: EST, 1997.

. Os Guarani-Missioneiros e o Colonialismo Luso no Brasil Meridional, Projetos Civilizatórios e Faces da Identidade Étnica (1750-1798). Porto Alegre, Martins Livreiro, 2005.

LAYTANO, Dante de. Guia Histórico de Rio Pardo. Porto Alegre: Edição da Prefeitura Municipal de Rio Pardo, 1979.

LEITMAN, Spencer. Raízes sócio-econômicas da guerra dos Farrapos. Rio de Janeiro, Graal, 1979.

MAEDER, Ernesto J. A. Missiones del Paraguay: conflicto y disolución de la sociedad guaraní. Madri: MAPFRE, 1992.

MAGALHÃES J. B. (Cel). Osório: síntese de seu perfil histórico. Rio de Janeiro, Biblioteca do Exército, 1977. Osório: símbolo de um povo, síntese de uma época. Rio de Janeiro: Livraria AGIR Editora, 1946.

MAXWELL, Kenneth. Marquês de Pombal, paradoxo do Iluminismo. São Paulo: Paz e Terra, 1996.

MELO, Karina M. R. S. e. "A aldeia dos Anjos durante a década de 1770: um olhar sobre as relações entre os indígenas e os portugueses". Raízes de Gravataí: memória, história e cidadania. TOMO I. JACHEMET, Célia Silva, BARROSO, Véra Lucia Maciel. Gravataí: Prefeitura Municipal: Casa dos Açores do Rio Grande do Sul. Porto Alegre: EST: Evangraf, 2011, p. 70-91.

MOTA, Lúcio Tadeu. "O Instituto Histórico Geográfico Brasileiro e as propostas de integração das comunidades indígenas no Estado Nacional”, Revista Diálogos, Maringá, 1998, v.2, p.149-176. 
MONTEIRO, John Manuel. Negros da Terra: Índios e bandeirantes na origem de São Paulo. São Paulo: Companhia das Letras, 1994.

. Tupis, tapuias e historiadores. Estudos de história indígena e do indigenismo. Tese apresentada para o concurso de Livre Docência em Antropologia na Universidade Estadual de Campinas, Campinas, 2001.

NEIS, Ruben. “A Aldeia de Nossa Senhora dos Anjos” in: Gravataí: História e Cultura. Gravataí, Secretaria Municipal de Educação e Cultura, 1987.

NEUMANN, Eduardo Santos. O trabalho guarani missioneiro no rio da Prata colonial, 1640-1750. Porto Alegre: Martins livreiro, 1996.

. "Fronteira e identidade: confrontos luso-guarani na Banda Oriental 1680-1757", Revista Complutense de História da América. Madri, 2000.

. "Mientras volaban correos por los pueblos: autogoverno e práticas letradas nas Missões Guarani - século XVIII", Horizontes Antropológicos. Porto Alegre, 2004. ano10, n.22, p.93-119.

- 'Práticas letradas guarani: produção e usos da escrita indígena (séculos XVII e XVIII)'. Tese de Doutorado apresentada pelo programa de Pós-Graduação em História da Universidade Federal do Rio de Janeiro, 2005.

NIMUENDAJÚ, Curt Unkel. As lendas da criação e destruição do mundo como fundamentos da religião dos Apapocúva-Guarani. São Paulo: Hucitec/Edusp, 1987.

OLIVEIRA, João Pacheco de. "O nosso governo”: os Ticuna e o regime tutelar. São Paulo. Marco Zero; Brasília: MCT/CNPq, 1988.

. “Uma Etnologia dos 'Índios Misturados': Situação Colonial, Territorialização e Fluxos Culturais", João Pacheco de OLIVEIRA (org.), A Viagem da Volta: Etnicidade, Política e Reelaboração Cultural no Nordeste Indígena, Rio de Janeiro, Contra Capa, 1999.

- "Cidadania, racismo e pluralismo: a presença das sociedades indígenas na organização do Estado Nacional brasileiro", in OLIVEIRA, João Pacheco de. Ensaios em Antropologia Histórica. Rio de Janeiro, Editora UFRJ, 1999.

OSÓRIO, Fernando Luís. História do General Osório. Rio de Janeiro, Typografia de G. Leuzinger \& Filhos, $1^{\text {o }}$ vol., 1894.

PADRÓN FAVRE, Oscar. Ocaso de un pueblo índio: historia del éxodo guaranímissionero al Uruguay, Bella Unión, San Borja del Ÿ̈. Durazno, Tierra Adentro, 2009. 
PERRONE-MOISÉS, Beatriz. "Índios Livres e Índios Escravos: Os princípios da legislação indigenista do período colonial (séculos XVI a XVIII)", in: Manuela Carneiro da Cunha. Historia dos Índios do Brasil (org.). São Paulo, Companhia das Letras, 1992.

PERROT, Michelle. Os Excluídos da História. (trad.) Rio de Janeiro, Paz e Terra, 1988.

PORTO, Aurélio. História das Missões Orientais do Uruguai. Porto Alegre: Livraria Selbach, 1943.

PRADO, Fabrício. "A presença luso-brasileira no Rio da Prata e o período cisplatino" in GRIJÓ, Luis Alberto; NEUMANN, Eduardo Santos (org.). Continente em armas: uma história da guerra no sul do Brasil. Rio de Janeiro, Apicuri, 2010, p. 69-96.

PUNTONI, Pedro. A Guerra dos Bárbaros. Povos indígenas e a colonização dos sertão nordestino do Brasil. 1650-1720. São Paulo: Tese de doutoramento - Programa de Pósgraduação de História Social da USP, 1998.

RIBEIRO, José Iran. "Nem oficiais, nem soldados: perfis dos militares de patentes intermediárias do Exército Imperial brasileiro durante a Guerra dos Farrapos" in Lócus: revista de História, Juiz de Fora, v. 15, n. 2, 2009, p. 110. Dossiê Saúde: profissões, ciências e políticas públicas.

RODRÍGUES, Mariângela. Tradición, identidad, mito y metáfora: mexicanos y chicanos en Califórnia. Ciudad de México. Ed. Miguel Angel Porrúa, 2005.

ROJAS, José Luis de. La etnohistória de América: los indígenas, protagonistas de su historia. [Seleccionado por Guillermo Wilde]. Buenos Aires, SB, 2008.

RUBERT, Arlindo. História da Igreja no Rio Grande do Sul: época colonial (1626/1822). Porto Alegre: EDIPUCRS, 1994.

RUSSELL-WOOD, A. J.R. Um mundo em movimento: os portugueses na África, Ásia e América (1415-1808). Lisboa: Difel, 1998.

SÁEZ, Oscar Calávia (Coord.). Revista de Indias. "Monográfico: La persistencia Guaraní". Madrid. Vol. LXIV, N. 230. Enero-abril, 2004. 
SAHLINS, Marshall. Ilhas de História. Rio de Janeiro, Zahar, 1987. Cultura na prática [tradução Vera Ribeiro]. Rio de Janeiro, Editora UFRJ, 2007. Metáforas Históricas e Realidades Míticas: estrutura nos primórdios da história do reino das ilhas Sandwich. Rio de Janeiro: Zahar, 2008.

SALEMA, Vasco da Costa. Achegas para a História da Cavalaria Portuguesa. Lisboa: Sociedade Histórica da Independência de Portugal, 2000.

SAMPAIO, Patrícia Maria Melo. Espelhos partidos. Etnia, Legislação e Desigualdade na Colônia: Sertões do Grão-Pará, c. 1755 - c.1823. Tese de Doutorado apresentada ao Programa de Pós-Graduação em História da Universidade Federal Fluminense, Niterói, 2001.

. “'Vossa Excelência mandará o que for servido...': políticas indígenas $e$ indigenistas na Amazônia Portuguesa do final do século XVIII" in Os índios na História: abordagens interdisciplinares, Revista Tempo, Rio de Janeiro, n 23, vol. 12, p. 39-55, Julho de 2007.

SANTOS, Corcino de Medeiros dos. "O índio e a civilização cristã ocidental: a aldeia de Nossa Senhora dos Anjos de Gravatai" in: Gravataí; do êxodo à composição étnica. Gravataí, Secretaria Municipal de Educação e Cultura, 1990.

SIDER, Gerald. "Identity as History, Ethnohistory, Ethnogenesis and Ethnocide in the Southeastern United States". Identities Global Studies in Culture and Power. New Hampshire, vol. 1. 1994.

SILVA, Edson. "Nós vencemos a guerra!"”: história, memória e leituras indígenas da Guerra do Paraguai, in Revista Clio, $\mathrm{n}^{\circ}$ 25.2. SILVA, Edson \& CARVALHO, Marcus J. M. de (orgs.). Recife, EDUFPE, 2007, p. 39-65.

SIRTORI, Bruna. Entre a cruz, a espada, a senzala e a aldeia. Hierarquias sociais em uma área periférica do Antigo Regime (1765-1784). Dissertação de mestrado apresentada ao Programa de Pós-graduação em História Social do Instituto de Filosofia e Ciência Sociais da Universidade Federal do Rio de Janeiro, Rio de Janeiro, 2008.

SOUZA, José Otávio Catafesto de. "Aos 'Fantasmas das Brenhas': etnografia, invisibilidade e etnicidade de populações originárias no sul do Brasil”" (tese de doutorado). Porto Alegre: PPGAS/UFRGS, 1998. 
SOUZA, Susana B.; PRADO, Fabrício. "Brasileiros na fronteira uruguaia: economia e política no século XIX", in GRIJÓ, Luiz Alberto; KÜHN, Fábio; GUAZELLI, César Augusto Barcellos; NEUMANN, Eduardo Santos (orgs.). Capítulos de Historia do Rio Grande do Sul. Porto Alegre, EDUFRGS, 2004, p. 121-146.

SPALDING, Karen. De índio a campesino: cambios en la estructura social del Peru colonial. Lima: Instituto de Estudios Peruanos, 1974.

THOMPSON, E. P. Costumes em Comum. (trad.) São Paulo, Cia. das Letras, 1998.

TOURON, Lucía Sala de; LA TORRE, Nelson; RODRÍGUEZ, Julio C. Artigas y su revolución agraria 1811-1820. Mexico, Siglo XXI, 1987.

VAINFAS, Ronaldo. A heresia dos índios: catolicismo e rebeldia no Brasil Colonial. São Paulo, Companhia das Letras, 1995.

VARGAS, Jonas Moreira. "O Rio Grande do Sul e a guerra do Paraguai”, in GRIJÓ, Luis Alberto; NEUMANN, Eduardo Santos (org.). Continente em armas: uma história da guerra no sul do Brasil. Rio de Janeiro, Apicuri, 2010.

VASCONCELOS, Genserico. História Militar do Brasil. A Campanha de 1851-1852. Rio de Janeiro, Ministério da Guerra, 1941.

WACHTEL, Nathan. La vision des vaincus. Les indiens du Péru devant la Conquête Espagnole 1530-1570. Gallimard, Paris, 1971.

"A aculturação", in História: novos problemas. LE GOFF, Jacques \& NORA, Pierre. (org.). Rio de Janeiro: Francisco Alves, 1995, p. 113-129.

WILDE, Guillermo. "Orden y ambigüedad en la formación territorial del Río de la Plata a fines del siglo XVIII", Horizontes Antropológicos, Porto Alegre, ano 9, n.19, p.105-135, julho de 2003.

Religión y poder en las misiones de guaraníes. Buenos Aires: SB, 2009. 